\title{
A synoptic review of the aloes (Asphodelaceae, Alooideae) of KwaZulu-Natal, an ecologically diverse province in eastern South Africa
}

\author{
Ronell R. Klopper ${ }^{1,2}$, Neil R. Crouch ${ }^{3,4}$, Gideon F. Smith ${ }^{5}$, Abraham E. van Wyk ${ }^{1,2}$ \\ I Biosystematics and Biodiversity Collections Division, South African National Biodiversity Institute, Private \\ Bag X101, Pretoria, 0002 South Africa 2 H.G.W.J. Schweickerdt Herbarium, Department of Plant and \\ Soil Sciences, University of Pretoria, Pretoria, 0002 South Africa 3 Biodiversity Research, Monitoring and \\ Assessment, South African National Biodiversity Institute, P.O. Box 52099, Berea Road, 4007 South Africa \\ 4 School of Chemistry \& Physics, University of KwaZulu-Natal, Durban, 4041 South Africa 5 Department of \\ Botany, Nelson Mandela University, P.O. Box 77000, Port Elizabeth, 6031 South Africa
}

Corresponding author: Ronell R. Klopper (R.Klopper@sanbi.org.za)

Academic editor: L. Peruzzi | Received 11 November 2019 | Accepted 31 January 2020 | Published 12 March 2020

Citation: Klopper RR, Crouch NR, Smith GF, Van Wyk AE (2020) A synoptic review of the aloes (Asphodelaceae, Alooideae) of KwaZulu-Natal, an ecologically diverse province in eastern South Africa. PhytoKeys 142: 1-88. https://doi. org/10.3897/phytokeys.142.48365

\begin{abstract}
The KwaZulu-Natal province of South Africa has a varied topography, geology and climate and presents diverse habitats that support a rich and diverse flora. Aloes are well represented in KwaZulu-Natal, with four genera [Aloe L., Aloiampelos Klopper \& Gideon F.Sm., Aloidendron (A.Berger) Klopper \& Gideon F.Sm. and Aristaloe Boatwr. \& J.C.Manning] and 49 taxa occurring in the province. Fourteen of these are endemic and eleven near-endemic to the province. A floristic treatment of the aloes of KwaZulu-Natal is presented in the form of a synoptic review. Included are an identification key to the aloes that occur naturally in the province, species-level distribution maps and accompanying images, so providing for the first time, an atlas of aloe occurrence in this part of the subcontinent.
\end{abstract}

\section{Keywords}

Aloe, Aloiampelos, Aloidendron, Aristaloe, conservation status, distribution map, Maputaland-PondolandAlbany Hotspot

Copyright Ronell R. Klopper et al. This is an open access article distributed under the terms of the Creative Commons Attribution License (CC BY 4.0), which permits unrestricted use, distribution, and reproduction in any medium, provided the original author and source are credited. 


\section{Table of Content}

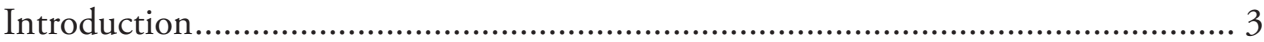

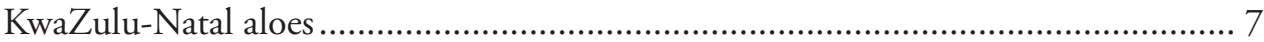

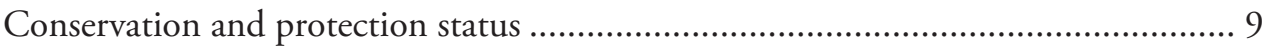

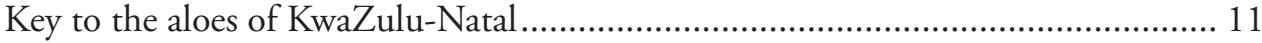

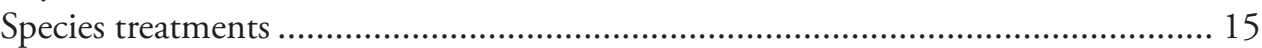

Aloiampelos tenuior (Haw.) Klopper \& Gideon F.Sm. ......................................... 15

Aloidendron barberae (Dyer) Klopper \& Gideon F.Sm....................................... 16

Aloidendron tongaense (Van Jaarsv.) Klopper \& Gideon F.Sm............................... 18

Aristaloe aristata (Haw.) Boatwr. \& J.C.Manning ................................................. 20

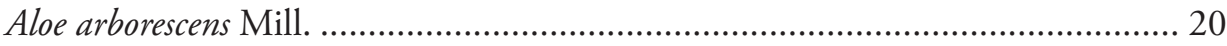

Aloe bergeriana (Dinter) Boatwr. \& J.C.Manning ................................................ 23

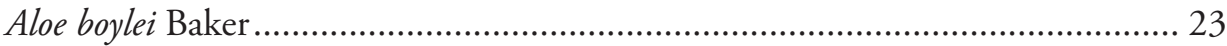

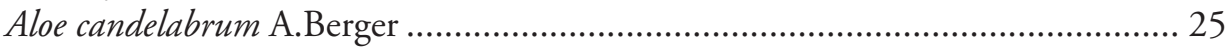

Aloe chabaudii Schönland var. chabaudii........................................................... 27

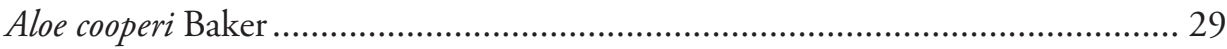

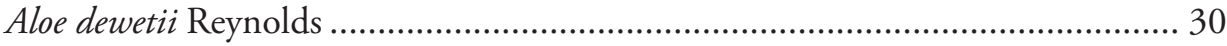

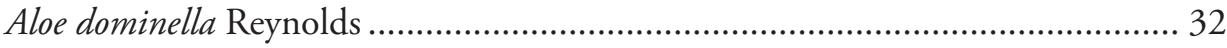

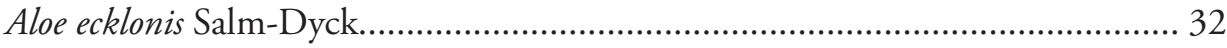

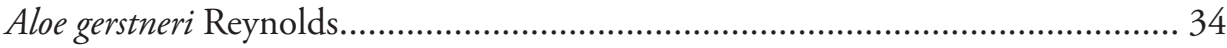

Aloe hlangapies Groenew............................................................................ 36

Aloe inconspicua Plowes ............................................................................... 36

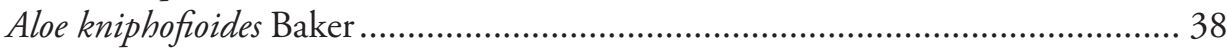

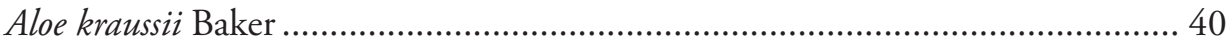

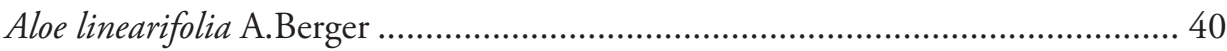

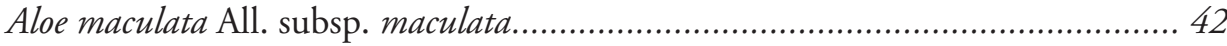

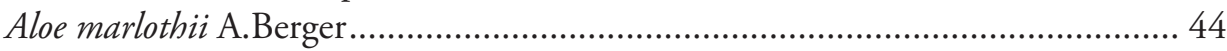

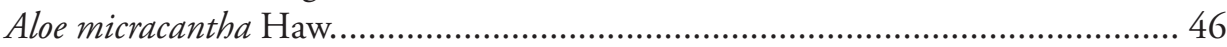

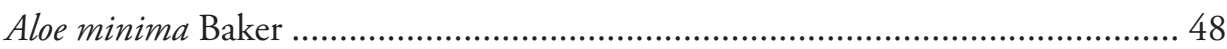

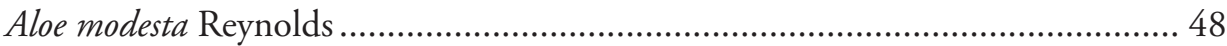

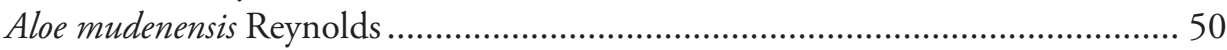

Aloe myriacantha (Haw.) Schult. \& Schult.f......................................................... 52

Aloe neilcrouchii Klopper \& Gideon F.Sm...................................................... 52

Aloe nicholsii Gideon F.Sm. \& N.R.Crouch ....................................................... 54

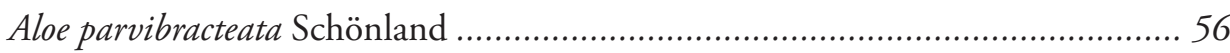

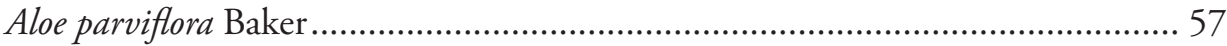

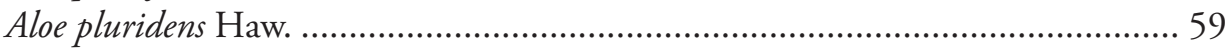

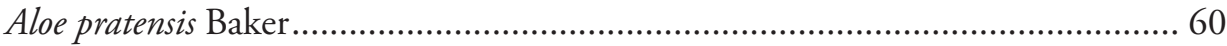

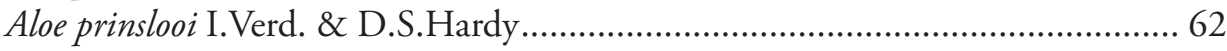

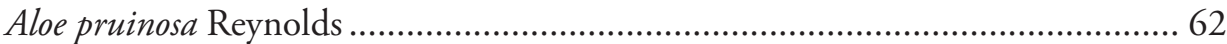

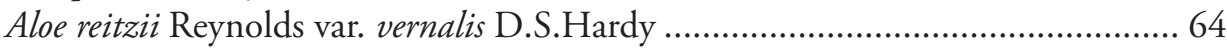

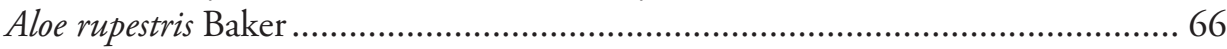




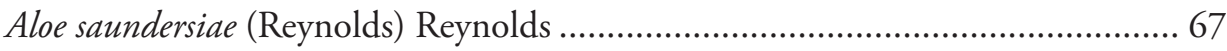

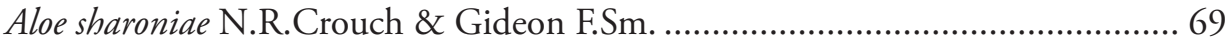

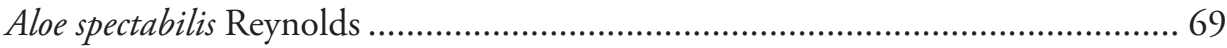

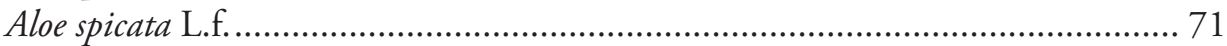

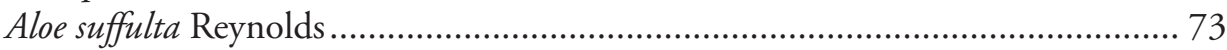

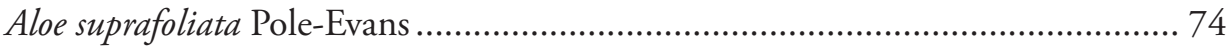

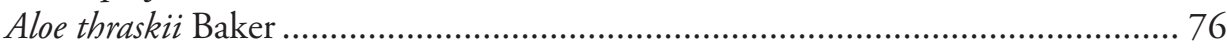

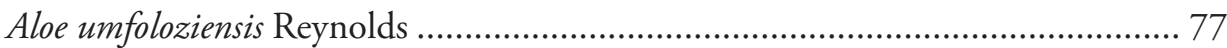

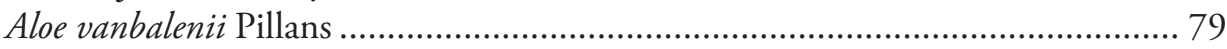

Aloe vanrooyenii Gideon F.Sm. \& N.R.Crouch ................................................. 80

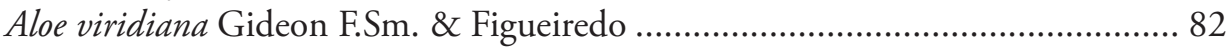

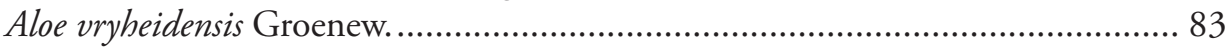

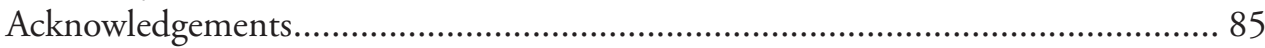

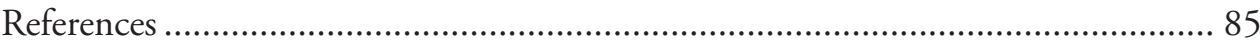

\section{Introduction}

The KwaZulu-Natal province covers an area of $\pm 92290 \mathrm{~km}^{2}$ in the southeast of South Africa (Raimondo et al. 2009). It has a $\pm 580 \mathrm{~km}$ long coastline (Palmer et al. 2011) with the warm Agulhas Current of the Indian Ocean in the east and is bordered in the south and southwest by the Eastern Cape province, in the west by the Free State province and Lesotho and, in the north, by the Mpumalanga province, Eswatini (formerly Swaziland) and Mozambique.

The main agricultural industry in KwaZulu-Natal is sugar production and vast areas of the province are covered with sugar cane plantations. Other agricultural activities include farming with sheep, cattle (dairy and beef), plantation forestry, citrus fruit, maize, sorghum, cotton, bananas, macadamia nuts and pineapples. Industrial areas with textile, chemical, vehicle and food-processing plants and oil refineries are mainly located near the main ports of Durban (east-central KwaZulu-Natal) and Richards Bay (north coast). Coastal dune mining for heavy metals and minerals is having a negative impact on the coastal dune vegetation and marine ecology along parts of the north coast of KwaZulu-Natal. The province is also a popular tourism destination, especially the coastal region and the high mountains of the Great Escarpment (Drakensberg) on the border with Lesotho (Palmer et al. 2011; http://en.wikipedia.org/wiki/KwaZulu-Natal).

Many areas in KwaZulu-Natal are densely populated or otherwise anthropogenically impacted, leading to the destruction or degradation of much natural vegetation. By $2005,43 \%$ of the natural habitat in the province was already transformed, with the rate of such change much higher than the national average (Jewitt et al. 2015). These authors demonstrated that, in the seven-year period 2005-2011, an alarming $7.6 \%$ more natural habit was lost to anthropogenic transformation of the landscape. Jewitt et al. (2015) determined that the main drivers of change in the KwaZulu-Natal landscape were agriculture, silviculture (plantation timber industry), built environ- 
ments (peri-urban expansion), mines and dam construction. Unsustainable farming practices, the cultivation of monocultures such as sugar cane, commercial timber plantations and dune mining have long been recognised as important drivers of habitat loss in the province (Van Wyk and Smith 2001; Steenkamp et al. 2004). The province includes two natural areas that have been declared UNESCO World Heritage Sites, namely the iSimangaliso Wetland Park and the uKhahlamba Drakensberg Park, where sensitive ecosystems are protected. Several other smaller protected areas are scattered throughout the province. These areas play a vital role in conserving natural habitats and the species they harbour and, concomitantly, service the ecotourism economy of the province (Cyrus and Robson 1980; http://en.wikipedia.org/wiki/KwaZulu-Natal).

The climate of KwaZulu-Natal ranges from temperate in the higher inland areas to subtropical or tropical along the coast. Maputaland, in the north-eastern corner of KwaZulu-Natal, is at the southern end of the tropics in Africa and many tropical plants and animals reach the southermost limit of their range here (Van Wyk 1996). The southern boundary of this true tropical area seems to follow the $18{ }^{\circ} \mathrm{C}$ mean midwinter isotherm (Poynton 1961, 1962). Mean summer temperatures in the high Drakensberg are below $22{ }^{\circ} \mathrm{C}$ (Van Wyk and Smith 2001) and in the low 20s to high 30 s at the coast (Palmer et al. 2011). Coastal temperatures $\left({ }^{\circ} \mathrm{C}\right)$ range from the low teens to mid-20s in winter (Palmer et al. 2011), while very low temperatures of below freezing with frost and snow are regularly recorded during winter along the Drakensberg Escarpment (Van Wyk and Smith 2001). Mean daily winter temperatures in the mid-teens are usually experienced throughout the midlands (Cyrus and Robson 1980). KwaZulu-Natal receives predominantly summer rain (November-March) and the relative humidity is usually high, especially near and along the coast. Mist and fog is fairly common in the midlands (Van Wyk and Smith 2001). Rainfall at the coast can be as high as 1 200-1 500 mm per annum (McDonald and Jarman 1985; Palmer et al. 2011), but is lower at inland localities, with as little as $650 \mathrm{~mm}$ in the northeastern interior and some of the drier river valleys (McDonald and Jarman 1985). Mean annual rainfall along the high Drakensberg Escarpment can be as high as 2000 mm (Van Wyk and Smith 2001).

Elevation ranges from sea level at the coast to an average crest height on the Drakensberg Escarpment, on the border between Lesotho and KwaZulu-Natal, of around $3377 \mathrm{~m}$ above sea level (a.s.l.) (McDonald and Jarman 1985; Van Wyk and Smith 2001). Soils in KwaZulu-Natal were formed from a variety of geological formations and under various climatic and topographical conditions. This leads to a very diverse soil profile throughout the province (McDonald and Jarman 1985).

The great variation found in climate, topography and geology throughout KwaZulu-Natal leads to high environmental heterogeneity. In addition, the proximity of the warm Agulhas Current may well have provided some climatic stability by acting as a buffer against periods of cooler climates in the past. This in turn has led to, inter alia, an exceptionally diverse vegetation and flora in the province (Ross 1972). KwaZulu-Natal harbours a large number of vegetation types (Mucina and Rutherford 2006) (see Fig. 1). Grassland predominates in the west of the province with savannah 
towards the east. Alpine vegetation occurs on the high Drakensberg Escarpment on the border with Lesotho. The Coastal Belt vegetation is regularly interrupted by large river systems, where a thicket-type vegetation is often present in the valleys. Numerous relatively small (relict) pockets of forest occur throughout the province and large wetlands are present, especially in the northeast (Maputaland; e.g. iSimangaliso) (Van Wyk and Smith 2001; Mucina 2018). KwaZulu-Natal harbours \pm 5250 indigenous plant species and infraspecific taxa. After the Eastern Cape (with \pm 6070 taxa), this is the second most diverse flora for any of the South African provinces. Around 390 species and infraspecific taxa (7.5\%) are endemic to the province and $\pm 470(9 \%)$ are regarded as taxa being of conservation concern (217 of which are threatened with extinction according to IUCN Red List criteria) (Raimondo and Von Staden 2009).

One of the 34 global biodiversity hotspots recognised by Conservation International (Mittermeier et al. 2004), namely, the Maputaland-Pondoland-Albany Hotspot (Steenkamp et al. 2004) covers most of KwaZulu-Natal. In addition, three major local centres of plant endemism fall partly in the province (Van Wyk and Smith 2001). These are the Maputaland, Pondoland and Drakensberg Alpine Centres of Endemism. Almost the entire KwaZulu-Natal is included in the Maputaland-Pondoland Region (sensu Van Wyk and Smith 2001; partly congruent with and representing the bulk of the Maputaland-Pondoland-Albany Hotspot), a floristic unit that is recognised at a higher level and includes the three above-mentioned Centres of Endemism and other smaller local centres of endemism (see Fig. 1). In terms of species numbers, the Maputaland-Pondoland Region is, after the Cape Floristic Region, the second-richest floristic region in southern Africa (Van Wyk and Smith 2001). This Region also extends northwards to around the Hoedspruit area in South Africa's Mpumalanga province, Massingir and Xai-Xai in Mozambique and in a southwesterly direction into the Eastern Cape province, to beyond East London. This entire region has an endemism level of around 25.7\% and also harbours a large number of threatened plants (Van Wyk and Smith 2001). The majority of endemics are confined to the most threatened vegetation type in the region, namely the Grassland Biome (Van Wyk and Smith 2001; Steenkamp et al. 2004).

The Drakensberg Alpine Centre of Endemism covers the central high-lying portion of the Drakensberg Mountains in Lesotho and western KwaZulu-Natal (see Fig. 1). The high Drakensberg (above $1800 \mathrm{~m}$ a.s.l.) is often recognised as a distinct floristic region, based on climatological and floristic evidence and the vegetation can be broadly classified into subalpine ( $\pm 1800-2800 \mathrm{~m}$ ) and alpine belts ( $\pm 2800-3500 \mathrm{~m}$ ) (Killick 1978; Van Wyk and Smith 2001). Levels of endemism of 13\% for strict endemics and 37\% for near-endemic taxa have been recorded for the Drakensberg Alpine Centre (Carbutt and Edwards 2006), also referred to as the Drakensberg Mountain Centre (Carbutt 2019), although endemic succulents are generally not well-represented in this region (e.g. see Smith and Willis 1999 on Crassula L.). The only aloe that is endemic to the Drakensberg Alpine Centre is the highly threatened spiral aloe, Aloe polyphylla Schönland ex Pillans (Van Wyk and Smith 2001). Note, however, that as Aloe polyphylla is confined to Lesotho, it is not treated in this atlas for the aloes of KwaZulu-Natal. 


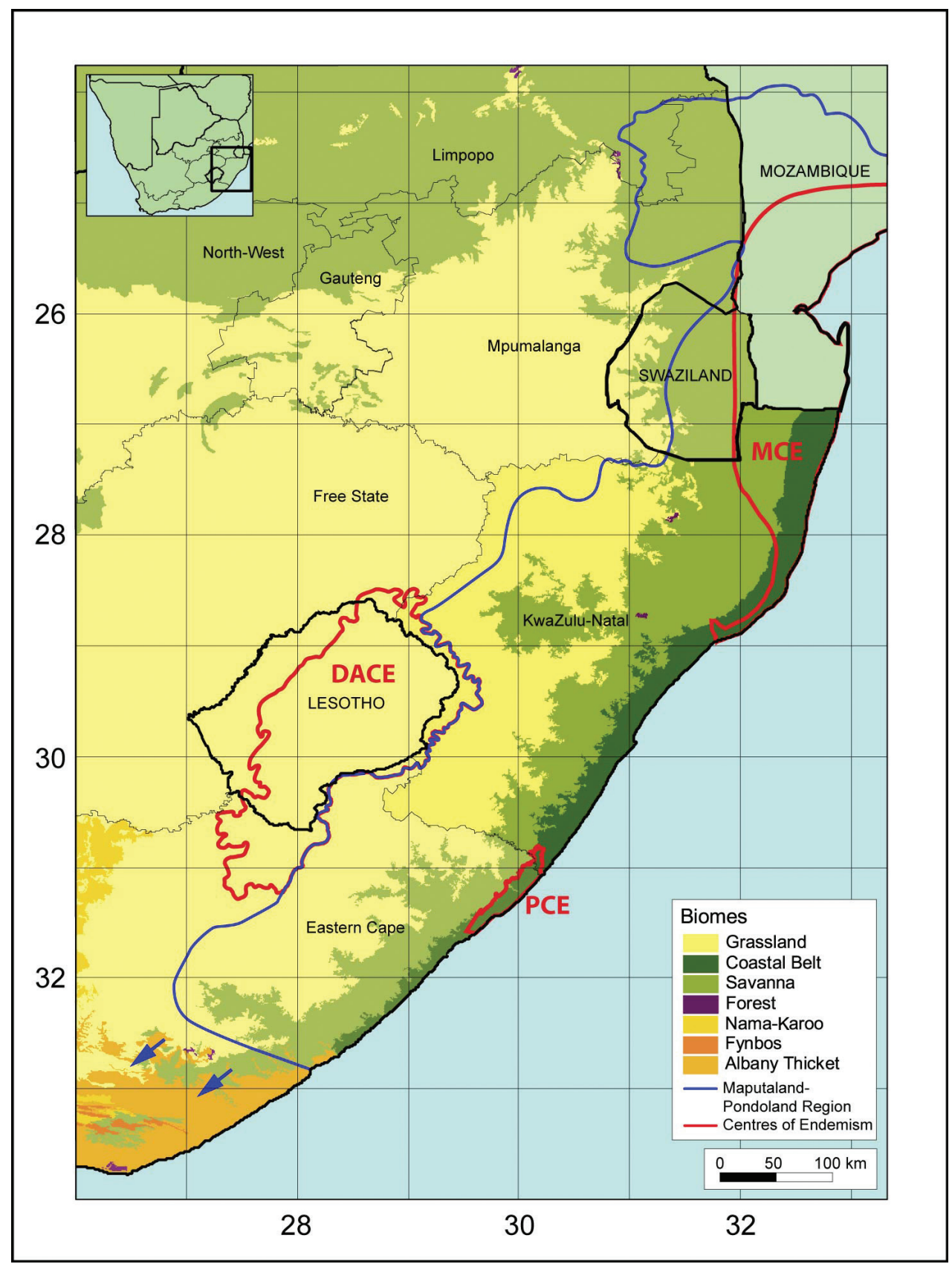

Figure I. Vegetation of the KwaZulu-Natal province of South Africa (based on Mucina and Rutherford 2006), the boundary of the Maputaland-Pondoland Region and the Maputaland (MCE), Pondoland (PCE) and Drakensberg Alpine (DACE) Centres of Endemism (based on Van Wyk and Smith 2001). 


\section{KwaZulu-Natal aloes}

South Africa harbours 27\% ( \pm 170 species and infraspecific taxa) of the world's \pm 630 species of aloe. This is more than for any other country. KwaZulu-Natal alone has 49 aloes (29\% of the aloes in South Africa). Of these, 14 (28.5\%) are endemic to the province and a further $11(22 \%)$ near-endemic. Near-endemic status is here applied to restricted range aloes where more than $75 \%$ of the distribution range falls within KwaZulu-Natal. Accordingly, a majority (51\%) of the aloes of KwaZulu-Natal are wholly or mostly restricted to the province. At least 31 aloes in KwaZulu-Natal (63\%) are endemic or near-endemic to the Maputaland-Pondoland Region (see Table 1). As a result, figures for aloe endemism are much higher than the $7.5 \%$ endemism estimated for the province or the average $25.7 \%$ endemism recorded for the flora of the Maputaland-Pondoland Region, making KwaZulu-Natal an important area for the conservation of aloes and their habitats.

A total of $12(24.5 \%)$ aloes have the largest part of their distribution ranges outside of KwaZulu-Natal and only marginally enter this province. The distribution range of eight $(16 \%)$ aloes extend to the north and south of KwaZulu-Natal, while 16 of the non-endemic aloes (33\%) reach either the southern or northern limit of their distribution ranges within the province (see Table 1).

Aloes in KwaZulu-Natal are represented by four genera (generic classification following Grace et al. 2013 and Manning et al. 2014): one scrambling aloe in the genus Aloiampelos Klopper \& Gideon F.Sm., two tree aloes in the genus Aloidendron (A.Berger) Klopper \& Gideon F.Sm., the monotypic Aristaloe Boatwr. \& J.C.Manning and 45 "true aloes" in the genus Aloe, including one member of Aloe section Chortolirion (A.Berger) Boatwr. \& J.C.Manning (previously treated at genus rank as Chortolorion A.Berger).

KwaZulu-Natal is especially rich in so-called grass aloes with no less than 18 species (37\% of the aloes treated here) (Craib 2005). This is around 55\% of the total number of grass aloes present in South Africa. Ten of these (55\% of grass aloes in KwaZuluNatal) are either endemic (six; 33\%) or near-endemic (four; 22\%) to the province (see Table 1). Considering that the Grassland Biome, which is the habitat of these grass aloes, is the most threatened vegetation type in the region (Van Wyk and Smith 2001; Steenkamp et al. 2004), the importance of grassland conservation in KwaZulu-Natal for the continued survival of these aloes cannot be over-emphasised. This is further highlighted by the fact that six (33\%) of the grass aloes in KwaZulu-Natal are regarded as threatened (see Table 2).

Another group that is very well represented in this province is the maculate aloes, with ten ( $20 \%$ of the aloes in KwaZulu-Natal) representatives, of which four ( $40 \%$ of maculate aloes in KwaZulu-Natal) are endemic and three (30\%) near-endemic (see Table 1). However, there is considerable debate on the delimitation of Aloe taxa in northern KwaZulu-Natal, especially regarding the maculate aloes. In this region, several species grow sympatrically and hybridisation is common amongst species with overlapping flowering periods, with the result that, at certain localities, species seem 
Table I. Checklist of endemic and near-endemic aloe taxa of KwaZulu-Natal, South Africa and the Maputaland-Pondoland Region. Restricted range aloes, where more than $75 \%$ of the distribution range falls within KwaZulu-Natal, are here regarded as near-endemic to the province. Also indicated are taxa that only have a minor part of their range in this province, but have their main distribution range outside of KwaZulu-Natal, as well as taxa that reach the limits of their distribution in this province. [N - reaches northern extreme of range; $\mathrm{NE}$ - reaches northeast of range; $\mathrm{S}$ - reaches southern extreme of range; $\mathrm{SE}$ - reaches south-eastern extreme of range; MPR - Maputaland-Pondoland Region endemic or near-endemic].

\begin{tabular}{|c|c|c|c|c|c|}
\hline $\begin{array}{r}\text { Taxon } \\
\end{array}$ & Endemic & Near-endemic & Minor range & Limit & MPR \\
\hline Aloiampelos tenuior & & & $\mathrm{X}$ & $\mathrm{N}$ & \\
\hline Aloidendron barberae & & & & & $\mathrm{X}$ \\
\hline Aloidendron tongaense & & & $\mathrm{X}$ & S & $\mathrm{X}$ \\
\hline Aristaloe aristata & & & $\mathrm{X}$ & $\mathrm{NE}$ & \\
\hline \multicolumn{6}{|l|}{ Aloe arborescens } \\
\hline Aloe bergeriana & & & $\mathrm{X}$ & SE & \\
\hline \multicolumn{6}{|l|}{ Aloe boylei } \\
\hline Aloe candelabrum & $\mathrm{X}$ & & & & $\mathrm{X}$ \\
\hline Aloe chabaudii var. chabaudii & & & $\mathrm{X}$ & $S$ & \\
\hline Aloe cooperi & & & & & $\mathrm{X}$ \\
\hline Aloe dewetii & & $\mathrm{X}$ & & & $\mathrm{X}$ \\
\hline Aloe dominella & & $\mathrm{X}$ & & & $\mathrm{X}$ \\
\hline Aloe ecklonis & & & $\mathrm{X}$ & & \\
\hline Aloe gerstneri & $\mathrm{X}$ & & & & $\mathrm{X}$ \\
\hline Aloe hlangapies & & $\mathrm{X}$ & & & $\mathrm{X}$ \\
\hline Aloe inconspicua & $\mathrm{X}$ & & & & $\mathrm{X}$ \\
\hline Aloe kniphofioides & & & $\mathrm{X}$ & $S$ & \\
\hline Aloe kraussii & $\mathrm{X}$ & & & & $\mathrm{X}$ \\
\hline Aloe linearifolia & & $\mathrm{X}$ & & & $\mathrm{X}$ \\
\hline \multicolumn{6}{|l|}{ Aloe maculata subsp. maculata } \\
\hline Aloe marlothii subsp. marlothii & & & & $S$ & \\
\hline Aloe marlothii subsp. orientalis & & & & $S$ & $\mathrm{X}$ \\
\hline Aloe micracantha & & & $\mathrm{X}$ & $\mathrm{N}$ & \\
\hline Aloe minima & & & & & $\mathrm{X}$ \\
\hline Aloe modesta & & & & $S$ & \\
\hline Aloe mudenensis & & $\mathrm{X}$ & & & $\mathrm{X}$ \\
\hline \multicolumn{6}{|l|}{ Aloe myriacantha } \\
\hline Aloe neilcrouchii & $\mathrm{X}$ & & & & $\mathrm{X}$ \\
\hline Aloe nicholsii & $\mathrm{X}$ & & & & $\mathrm{X}$ \\
\hline Aloe parvibracteata & & & & $S$ & \\
\hline Aloe parviflora & $\mathrm{X}$ & & & & $\mathrm{X}$ \\
\hline Aloe pluridens & & & $\mathrm{X}$ & $\mathrm{N}$ & \\
\hline Aloe pratensis & & & $\mathrm{X}$ & $\mathrm{N}$ & \\
\hline Aloe prinslooi & $\mathrm{X}$ & & & & $\mathrm{X}$ \\
\hline Aloe pruinosa & $\mathrm{X}$ & & & & $\mathrm{X}$ \\
\hline Aloe reitzii var. vernalis & $\mathrm{X}$ & & & & $\mathrm{X}$ \\
\hline Aloe rupestris & & $\mathrm{X}$ & & & $\mathrm{X}$ \\
\hline Aloe saundersiae & $\mathrm{X}$ & & & & $\mathrm{X}$ \\
\hline Aloe sharoniae & & $\mathrm{X}$ & & & $\mathrm{X}$ \\
\hline Aloe spectabilis & $\mathrm{X}$ & & & & $\mathrm{X}$ \\
\hline Aloe spicata & & & $\mathrm{X}$ & $S$ & \\
\hline Aloe suffulta & & & & $S$ & $\mathrm{X}$ \\
\hline Aloe suprafoliata & & $\mathrm{X}$ & & & $\mathrm{X}$ \\
\hline Aloe thraskii & & $\mathrm{X}$ & & & $\mathrm{X}$ \\
\hline Aloe umfoloziensis & & $\mathrm{X}$ & & & $\mathrm{X}$ \\
\hline Aloe vanbalenii & & $\mathrm{X}$ & & & $\mathrm{X}$ \\
\hline Aloe vanrooyenii & $\mathrm{X}$ & & & & $\mathrm{X}$ \\
\hline Aloe viridiana & $\mathrm{X}$ & & & & $\mathrm{X}$ \\
\hline Aloe vryheidensis & & & $\mathrm{X}$ & $S$ & \\
\hline Total $=49$ & 14 & 11 & 12 & 16 & 31 \\
\hline
\end{tabular}


to intergrade. This makes identification difficult and in several areas plants can only be positively identified during the flowering season. A particular example is the Aloe maculata / Aloe parvibracteata-complex of maculate aloes that flower in mid-winter (southern hemisphere), during June and July. A gradual cline has been observed from south to north amongst Aloe maculata All., Aloe umfoloziensis Reynolds and Aloe parvibracteata Schönland (Reynolds 1950). At their geographical extremes, it is, however, possible to tell these three species apart.

This synoptic review provides a complete floristic treatment of the aloes of $\mathrm{KwaZu}$ lu-Natal. It also contains an identification key to the aloes of this province, along with species-level distribution maps and accompanying images, giving for the first time, an atlas of aloe occurrence in this part of the subcontinent. To prevent confusion between Aloe, Aloiampelos and Aristaloe in the species treatments, we do not abbreviate generic names to the first letter.

\section{Conservation and protection status}

Aloes are protected under both provincial legislation and international convention. All KwaZulu-Natal aloes are listed as specially protected under KwaZulu-Natal nature conservation legislation (Province of KwaZulu-Natal 1997) and may, therefore, not be removed from the wild without the necessary permits. Furthermore, all species of Aloe [or, at least, species treated in this genus prior to the new generic classification published in Grace et al. (2013) and Manning et al. (2014); see Grace and Klopper (2014)] [except for Aloe vera (L.) Burm.f.] appear on CITES (Convention on the International Trade in Endangered Species of Wild Fauna and Flora) Appendices, meaning that international trade in aloes is controlled to prevent utilisation that would be incompatible with their survival. The taxa occurring in KwaZulu-Natal are all included in Appendix II (CITES 2018), necessitating CITES permit arrangements for such trade. In practice, most aloes are nonetheless subjected to ongoing illegal removal of plants from the wild, coupled to impacts resulting from anthropogenic degradation of their habitats.

Conservation status and threats to the survival of each species are given here according to Raimondo et al. (2009) and the Red List of South African Plants website (http:// redlist.sanbi.org), reflecting the 2001 IUCN Red List categories (IUCN 2001). Where an assessment is not available in these sources, the information given was obtained from Lize von Staden (personal communication) of the Threatened Species Programme at the South African National Biodiversity Institute in Pretoria. Many of these conservation statuses are still under review and might change as further evidence becomes available. The majority of aloes in KwaZulu-Natal (30 taxa or 61\%) falls in the Least Concern (LC) category. For Aloe cooperi Baker, the population trend is considered to be Declining. Nineteen $(39 \%)$ of the KwaZulu-Natal aloes are regarded as taxa of conservation concern (NT, VU, EN, CR): seven taxa (14\%) are Near-Threatened (NT). A total of twelve aloes (24\%) are threatened (VU, EN, CR): three (6\%) are Vulnerable (VU); eight $(16 \%)$ are Endangered (EN); and one (2\%) is Critically Endangered (CR) (see Table 2). 
Table 2. Red-List categories for the aloe taxa in KwaZulu-Natal. [Least Concern (LC), Near-threatened $(\mathrm{NT})$, Vulnerable (VU), Endangered (EN), Critically Endangered (CR); Taxa of conservation concern = NT, VU, EN, CR; Threatened taxa = VU, EN, CR].

\begin{tabular}{|c|c|c|c|c|c|}
\hline Taxon & LC & NT & VU & EN & $\mathbf{C R}$ \\
\hline Aloiampelos tenuior & $\mathrm{X}$ & & & & \\
\hline Aloidendron barberae & $\mathrm{X}$ & & & & \\
\hline Aloidendron tongaense & $\mathrm{X}$ & & & & \\
\hline Aristaloe aristata & $\mathrm{X}$ & & & & \\
\hline Aloe arborescens & $\mathrm{X}$ & & & & \\
\hline Aloe bergeriana & $\mathrm{X}$ & & & & \\
\hline Aloe boylei & $\mathrm{X}$ & & & & \\
\hline Aloe candelabrum & & $\mathrm{X}$ & & & \\
\hline Aloe chabaudii var. chabaudii & $\mathrm{X}$ & & & & \\
\hline Aloe cooperi & $\mathrm{X}$ & & & & \\
\hline Aloe dewetii & $\mathrm{X}$ & & & & \\
\hline Aloe dominella & & $\mathrm{X}$ & & & \\
\hline Aloe ecklonis & $\mathrm{X}$ & & & & \\
\hline Aloe gerstneri & & & & $\mathrm{X}$ & \\
\hline Aloe blangapies & & & $\mathrm{X}$ & & \\
\hline Aloe inconspicua & & & & $\mathrm{X}$ & \\
\hline Aloe kniphofioides & & $\mathrm{X}$ & & & \\
\hline Aloe kraussii & & & & $\mathrm{X}$ & \\
\hline Aloe linearifolia & $\mathrm{X}$ & & & & \\
\hline Aloe maculata subsp. maculata & $\mathrm{X}$ & & & & \\
\hline Aloe marlothii subsp. marlothii & $\mathrm{X}$ & & & & \\
\hline Aloe marlothii subsp. orientalis & $\mathrm{X}$ & & & & \\
\hline Aloe micracantha & & $\mathrm{X}$ & & & \\
\hline Aloe minima & $\mathrm{X}$ & & & & \\
\hline Aloe modesta & & & & $\mathrm{X}$ & \\
\hline Aloe mudenensis & & $\mathrm{X}$ & & & \\
\hline Aloe myriacantha & $\mathrm{X}$ & & & & \\
\hline Aloe neilcrouchii & & & & $\mathrm{X}$ & \\
\hline Aloe nicholsii & & & & & $\mathrm{X}$ \\
\hline Aloe parvibracteata & $\mathrm{X}$ & & & & \\
\hline Aloe parviflora & & & $\mathrm{X}$ & & \\
\hline Aloe pluridens & $\mathrm{X}$ & & & & \\
\hline Aloe pratensis & $\mathrm{X}$ & & & & \\
\hline Aloe prinslooi & & & & $\mathrm{X}$ & \\
\hline Aloe pruinosa & & & & $\mathrm{X}$ & \\
\hline Aloe reitzii var. vernalis & & & $\mathrm{X}$ & & \\
\hline Aloe rupestris & $\mathrm{X}$ & & & & \\
\hline Aloe saundersiae & & & & $\mathrm{X}$ & \\
\hline Aloe sharoniae & $\mathrm{X}$ & & & & \\
\hline Aloe spectabilis & $\mathrm{X}$ & & & & \\
\hline Aloe spicata & $\mathrm{X}$ & & & & \\
\hline Aloe suffulta & $\mathrm{X}$ & & & & \\
\hline Aloe suprafoliata & $\mathrm{X}$ & & & & \\
\hline Aloe thraskii & & $\mathrm{X}$ & & & \\
\hline Aloe umfoloziensis & & $\mathrm{X}$ & & & \\
\hline Aloe vanbalenii & $\mathrm{X}$ & & & & \\
\hline Aloe vanrooyenii & $\mathrm{X}$ & & & & \\
\hline Aloe viridiana & $\mathrm{X}$ & & & & \\
\hline Aloe vryheidensis & $\mathrm{X}$ & & & & \\
\hline Total $=49$ & 30 & 7 & 3 & 8 & 1 \\
\hline
\end{tabular}




\section{Key to the aloes of KwaZulu-Natal}

Note. To reliably identify aloes species, knowledge of the morphology of mature plants and their reproductive structures and, often, their geographical origin, are essential. Accordingly, this key does not cater for juvenile or sterile material and only applies to plants in the wild or collected/cultivated ones of known provenance.

1 Tangled shrubs with very slender stems; leaves cauline dispersed

Aloiampelos tenuior

- $\quad$ Plants do not form tangled shrubs, stems more robust when present; leaves

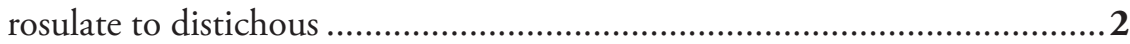

2 Arborescent plants with stems longer than $1 \mathrm{~m}$, usually longer than $2 \mathrm{~m} . . .3$

- $\quad$ Acaulescent plants or plants with stems shorter than $1 \mathrm{~m}$...........................13

3 Stems dichotomously branched, without persistent dried leaves...................4

- $\quad$ Stems simple or branched, with persistent dried leaves.................................5

4 Tree aloe of up to $18 \mathrm{~m}$ high; leaves $60-90 \mathrm{~cm}$ long; inflorescence $0.4-0.6 \mathrm{~m}$ high, 3-branched from a single point; raceme cylindrical, 20-30 cm long; flowers rose to rose-pink, 33-37 mm long; sparsely scattered in a broad coastal zone throughout KwaZulu-Natal, but absent from most of the Maputaland Centre

Aloidendron barberae

Tree aloe of up to $8 \mathrm{~m}$ high; leaves $40-59 \mathrm{~cm}$ long; inflorescence $\pm 0.35 \mathrm{~m}$ high, up to 6-branched; raceme capitate, $4-6 \mathrm{~cm}$ long; flowers yellowishorange, 47-50 mm long; confined to the Maputaland Center of Endemism.

Inflorescence simple or occasionally up to 2-branched

Aloidendron tongaense Much-branched shrub; pedicels $35-40 \mathrm{~mm}$ long; flowers scarlet to yellow, $\pm 40 \mathrm{~mm}$ long, cylindrical Aloe arborescens Stem simple or sometimes few-branched; pedicels absent; flowers pinkishbrown to greenish-yellow, up to $20 \mathrm{~mm}$ long, campanulate

Stem erect to decumbent; leaves spreading to recurved; inflorescence erect; raceme 4-5 cm wide; ovary uniformly green. Aloe spicata Stem procumbent to shortly suberect, sometimes absent; leaves arcuate-erect to slightly spreading; inflorescence oblique to erect; raceme 5-7 mm wide; ovary green with red line longitudinally down the three broad angles

Aloe vryheidensis

Racemes horizontal or spreading to suboblique; flowers secund

Aloe marlothii

Racemes erect; flowers not secund.

9 Leaves obscurely lineate; floral bracts $\pm 20 \mathrm{~mm}$ long; pedicels $30-35 \mathrm{~mm}$ long; flowers $40-45 \mathrm{~mm}$ long

Aloe pluridens

- Leaves without spots or lines; floral bracts shorter than $10 \mathrm{~mm}$; pedicels shorter than $6 \mathrm{~mm}$; flowers shorter than $35 \mathrm{~mm}$....... 
11 Leaves $30-70 \mathrm{~cm}$ long, without surface prickles or spines; racemes $\pm 7 \mathrm{~cm}$ wide; floral bracts $\pm 1 \mathrm{~mm}$ long; flowers $15-50 \mathrm{~mm}$ long.

Aloe rupestris Leaves $\pm 100 \mathrm{~cm}$ or longer, with spines in median line on lower surface or with copious surface spines; racemes wider than $9 \mathrm{~mm}$; floral bracts longer than $4 \mathrm{~mm}$; flowers $\pm 25 \mathrm{~mm}$ and longer

12 Leaves suberect to spreading, $\pm 100 \times 12-15 \mathrm{~cm}$, usually with copious spines on both surfaces; floral bracts $4-5 \mathrm{~mm}$ long; flowers $\pm 32 \mathrm{~mm}$ long

Aloe spectabilis

Leaves gracefully recurved, $\pm 160 \times 22 \mathrm{~cm}$, lower surface sometimes with few spines in median line; floral bracts $\pm 9 \mathrm{~mm}$ long; flowers $\pm 25 \mathrm{~mm}$ long.......

Aloe thraskii

13 Leaves thick and succulent, usually with fierce marginal teeth 14 Leaves thin and not very succulent, usually with small marginal teeth; grass aloes

Leaves with tuberculate spots or spines on lower surface, up to $17 \mathrm{~cm}$ long ...

Leaves without surface spines, if spines are present on median line of lower surface, then leaves longer than $40 \mathrm{~cm}$

Leaves with several scattered small, white, subtuberculate to spinulescent spots on both surfaces, $8-10 \times 1-2 \mathrm{~cm}$, marginal teeth 1-2 mm long; peduncle mostly without sterile bracts

Aristaloe aristata Leaves with few scattered brown spines on lower surface, especially along median line, 10-17 $\times 4-6 \mathrm{~cm}$, marginal teeth $\pm 5 \mathrm{~mm}$ long; peduncle covered with large imbricate sterile bracts.....

Aloe pratensis

16 Leaves with numerous spots on one or both surfaces, often in confluent transverse bands; flowers usually with globose basal swelling

Leaves without spots, sometimes with a few scattered spots only; flowers without globose basal swelling

17 Inflorescence with very slender peduncle, twining or climbing, requiring support from surrounding vegetation Aloe suffulta Inflorescence with robust peduncle, not climbing, stands erect without support from surrounding vegetation.

19 Flowers pale whitish-green, tinged with pink, 13-17 mm long, globose basal swelling not very prominent Aloe prinslooi

- $\quad$ Flowers salmon pink to orange or red, longer than $30 \mathrm{~mm}$, with prominent globose basal swelling.

Inflorescence $0.4-1.0 \mathrm{~m}$ high; racemes $10-12 \mathrm{~cm}$ long; floral bracts $12-$ $23 \mathrm{~mm}$ long; pedicels $35-45 \mathrm{~mm}$ long....... Aloe maculata subsp. maculata Inflorescence 1.0-1.5 m high; racemes 7-9 cm long; floral bracts 8-12 mm long; pedicels $10-15 \mathrm{~mm}$ long. 
$21 \quad$ Rosettes suckering profusely to form large dense groups ...........................22

- $\quad$ Rosettes usually solitary or sometimes suckering to form small groups......23

22 Leaves with markings more pronounced on lower surface; flowers light to dark flesh pink, with bloom, 28-30 mm long........................Aloe viridiana

- $\quad$ Leaves usually without markings on lower surface; flowers dull to somewhat glossy red, without bloom, 30-40 mm long Aloe parvibracteata

23 Inflorescence 1- or 2-branched; floral bracts 8-10 mm long; peduncle cannot support weight of very large mature capsules and bends towards ground

Aloe vanrooyenii

Inflorescence with more than four branches; floral bracts longer than $10 \mathrm{~mm}$; peduncle remains erect in fruiting stage

Inflorescence 4- to 8-branched; pedicels $20-25 \mathrm{~mm}$ long; flowers bright, without a powdery bloom, $25-35 \mathrm{~mm}$ long Aloe mudenensis Inflorescence up to 12-branched; pedicels up to $20 \mathrm{~mm}$ long; flowers dull, with powdery bloom, up to $\pm 40 \mathrm{~mm}$ long....

Rosettes always acaulescent, erect; leaves glossy, without spots on the lower surface, marginal teeth up to $10 \mathrm{~mm}$ long; inflorescence $2-3 \mathrm{~m}$ high; perianth $14 \mathrm{~mm}$ across ovary

Aloe dewetii

Rosettes usually with very short procumbent stem; leaves with heavy powdery bloom, with spots more numerous on lower surface, marginal teeth 3-4 mm long; inflorescence 1.4-2.0 m high; perianth $8 \mathrm{~mm}$ across ovary

Aloe pruinosa

26 Leaves not obscurely lineate; raceme $30-40 \mathrm{~cm}$ long; pedicels up to $5 \mathrm{~mm}$ long; flowers pointing downwards and pressed against stalk.... Leaves obscurely lineate; raceme shorter than $30 \mathrm{~cm}$; pedicels $14-25 \mathrm{~mm}$ long; flowers spreading to pendent, but not pressed against stalk 28 Leaves with marginal teeth $10-15 \mathrm{~mm}$ apart; inflorescence $1.0-1.3 \mathrm{~m}$ high, simple in young plants, 1- to 3-branched in mature plants; floral bracts $\pm 18 \mathrm{~mm}$ long; flowers yellowish-orange, $24-30 \mathrm{~mm}$ long .....Aloe gerstneri Leaves with marginal teeth $\pm 5 \mathrm{~mm}$ apart; inflorescence $0.70-0.75 \mathrm{~m}$ high, 2- to 4-branched; floral bracts $\pm 6 \mathrm{~mm}$ long; flowers bright red above, lemon yellow below, 32-40 $\mathrm{mm}$ long Aloe reitzii var. vernalis

28 Rosettes usually solitary; inflorescence simple Aloe suprafoliata Rosettes suckering to form dense groups; inflorescence branched. 29

29 Inflorescence 6- to 12-branched; racemes rather lax; floral bracts 3-6 mm long; flowers usually pale red, with stamens and style exserted to $2 \mathrm{~mm}$

Aloe chabaudii var. chabaudii

Inflorescence 2- or 3-branched; racemes rather dense; floral bracts up to $15 \mathrm{~mm}$ long; flowers usually orange-yellow, with stamens and style exserted to $12 \mathrm{~mm}$. Aloe vanbalenii

$30 \quad$ Plants with an underground bulb-like swelling of the leaf bases ................31

31 Racemes subcapitate; flowers scented Aloe modesta Racemes cylindrical; flowers unscented 
Inflorescence $\pm 0.15 \mathrm{~m}$ high; raceme very dense; pedicels absent

Aloe inconspicua

Inflorescence longer than $0.2 \mathrm{~m}$ high; raceme lax; pedicels present (short or long)

33 Flowers sub-erect to horizontal, pale pink to coral pink with darker median stripes on perianth segments, with bilabiate mouth.

Aloe bergeriana Flowers pendent, pale pink to scarlet, green-tipped, with mouth not bilabiate. Aloe kniphofioides

Inflorescence up to $0.3 \mathrm{~m}$ high; flowers $15-20 \mathrm{~mm}$ long, with bilabiate upturned mouth

Aloe myriacantha

Inflorescence longer than $0.3 \mathrm{~m}$; flowers longer than $25 \mathrm{~mm}$, with mouth not bilabiate or upturned

Leaves with the margin toothed throughout; inflorescence sometimes shorter than the leaves; floral bracts flat, not clasping the pedicels.

Aloe cooperi Leaves with no marginal teeth in the upper 2/3; inflorescence longer than the leaves; floral bracts clasping the pedicels. Aloe sharoniae

Leaves up to $3.5 \mathrm{~cm}$ wide.

Leaves usually wider than $3.5 \mathrm{~cm}$

Leaves wider than $2 \mathrm{~cm}$

Leaves up to $1 \mathrm{~cm}$ wide

Rosettes usually solitary; flowers 25-40 mm long, mouth not upturned

Aloe micracantha

Rosettes usually in dense groups; flowers 13-16 mm long, mouth distinctly upturned.

Aloe nicholsii

Flowers yellow to greenish-yellow .41

Flowers dull or greenish-white to pink or purple.

Rosettes in dense groups; leaves rosulate; raceme $\pm 4 \mathrm{~cm}$ long; flowers $13-$ $18 \mathrm{~mm}$ long, with stamens and style exserted 4-7 $\mathrm{mm}$

Aloe dominella

Rosettes usually solitary, sometimes in small groups; leaves usually distichous; raceme $\pm 2 \mathrm{~cm}$ long; flowers $\pm 12 \mathrm{~mm}$ long, with stamens and style exserted to $2 \mathrm{~mm}$

Aloe linearifolia Leaves up to $10 \mathrm{~cm}$ long; inflorescence shorter than $0.2 \mathrm{~m}$ Aloe saundersiae Leaves longer than $20 \mathrm{~cm}$; inflorescence taller than $0.25 \mathrm{~m}$

Leaves rosulate, $25-35 \times 0.4-0.6 \mathrm{~cm}$; inflorescence $0.25-0.50 \mathrm{~m}$ high; peduncle smooth; flowers $10-11 \mathrm{~mm}$ long....

Aloe minima Leaves distichous or rosulate, $20-25 \times 0.6-0.8 \mathrm{~cm}$; inflorescence $\pm 0.4 \mathrm{~m}$ high; peduncle with numerous small spines on lower part; flowers $\pm 8 \mathrm{~mm}$ long 
46 Stem up to $0.95 \mathrm{~m}$ long, decumbent to erect, branched; inflorescence 0.6$0.8 \mathrm{~m}$ high; floral bracts $\pm 30 \mathrm{~mm}$ long; flowers $\pm 45 \mathrm{~mm}$ long

Aloe neilcrouchii

- $\quad$ Stem absent or very short, erect, usually simple; inflorescence up to $0.6 \mathrm{~m}$ high; floral bracts shorter than $25 \mathrm{~mm}$; flowers up to $40 \mathrm{~mm}$ long.

47 Leaves erect, 50-60 cm long; floral bracts 20-23 mm long; pedicels 40$45 \mathrm{~mm}$ long; flowers $30-40 \mathrm{~mm}$ long.... Aloe boylei

- $\quad$ Leaves erectly spreading, 30-40 cm long; floral bracts $10-15 \mathrm{~mm}$ long; pedicels 30-40 mm long; flowers $20-24 \mathrm{~mm}$ long. Aloe ecklonis

\section{Species treatments}

Species are arranged alphabetically according to species name, with the minor genera treated before the true aloes. Only common names that are relevant to KwaZulu-Natal are given. Further common names can be found in Grace et al. (2011).

E indicates taxa that are endemic to KwaZulu-Natal.

$\mathrm{NE}$ indicates taxa that are near-endemic to KwaZulu-Natal (more than $75 \%$ of the distribution range falls within this province).

\section{Aloiampelos tenuior (Haw.) Klopper \& Gideon F.Sm.}

Syn. Aloe tenuior Haw.

Common names. Fence aloe, gardener's aloe (English); heiningaalwyn, heuningaalwyn (Afrikaans).

Description. Tangled shrub of $0.6 \mathrm{~m}$ or higher. Stems slender, $1-3 \mathrm{~m}$ long, branched low down or higher, erectly spreading or scandent to recurved or decumbent, without persistent dried leaves. Leaves cauline dispersed, erectly spreading, glaucous green, without spots, linear-lanceolate, $10-18 \mathrm{~cm}$ long, $1.0-2.2 \mathrm{~cm}$ wide; sheath obscurely green-lineate, not auriculate, $0.5-2.5 \mathrm{~cm}$ long; margin narrow, white, cartilaginous, with minute, white teeth, up to $0.5 \mathrm{~mm}$ long, 1-2 mm apart. Inflorescence 0.3-0.4 m high, ascending to erect, simple or 1- or 2-branched. Racemes cylindrical, slightly acuminate, $10-20 \mathrm{~cm}$ long, rather dense to dense. Floral bracts $\pm 5 \mathrm{~mm}$ long, 1-2 mm wide. Pedicels 3-5 mm long. Flowers: perianth yellow, orange or red with yellow tips, $11-15 \mathrm{~mm}$ long, $\pm 2 \mathrm{~mm}$ across ovary, very slightly narrowed above ovary, widening towards mouth, cylindrical; outer segments free for 3-6 $\mathrm{mm}$; stamens and style exserted 4-6 mm.

Flowering time. (August) October-December (May).

Habitat. Often in open habitats on sandy soils, more rarely in thicket vegetation, sometimes on steep slopes. In contrast, other species of Aloiampelos that do not occur in KwaZulu-Natal, such as A. ciliaris (Haw.) Klopper \& Gideon F.Sm. from the Eastern Cape, more commonly occur in thicket or fynbos. 


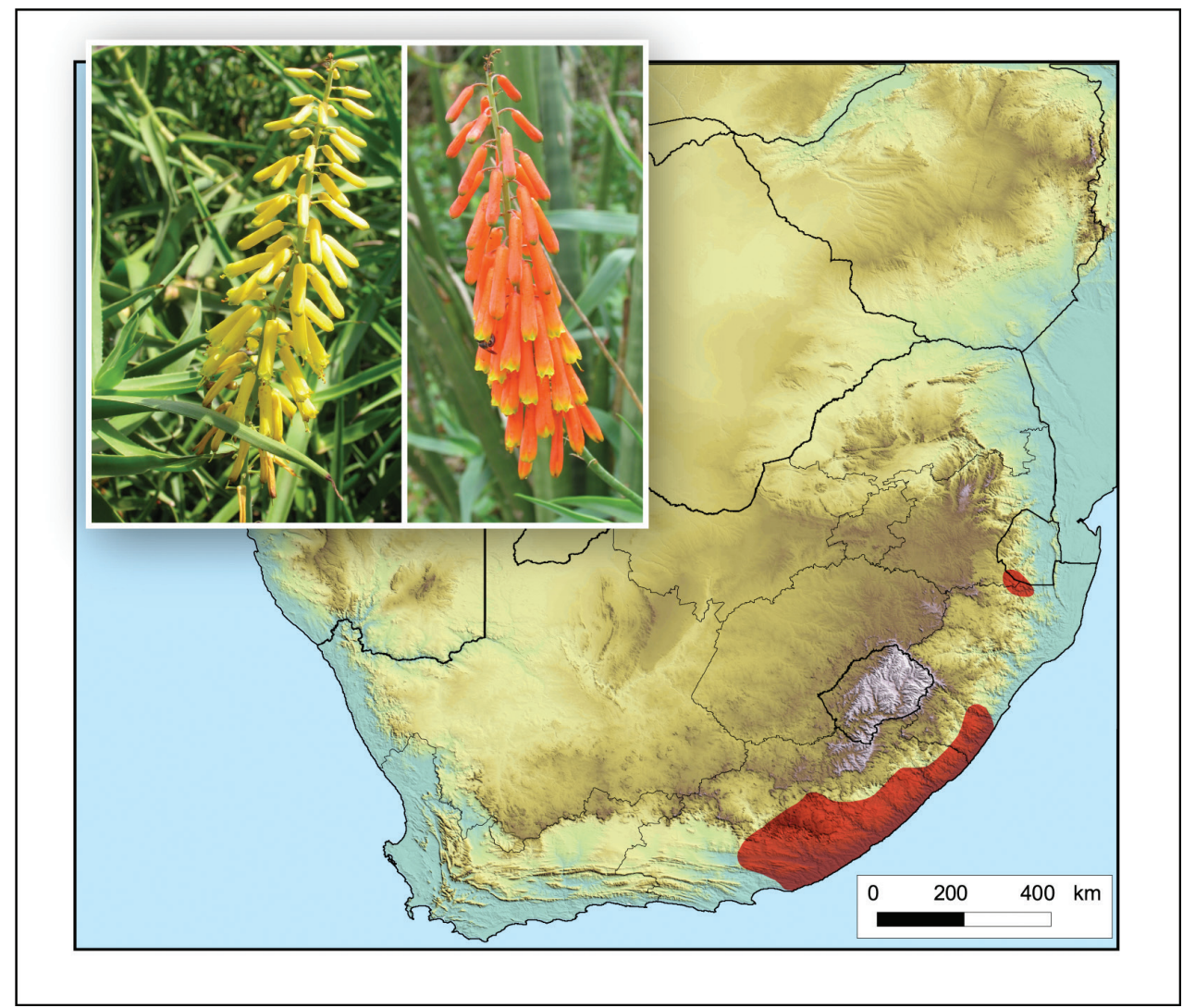

Figure 2. Aloiampelos tenuior. Photos: N.R. Crouch.

Diagnostic characters. Aloiampelos tenuior is the only aloe indigenous to KwaZulu-Natal that forms an untidy tangled shrub with thin slender stems. Also diagnostic is its cauline dispersed, blue-green leaves, with distinct sheaths that are obscurely lined. Racemes are elongated, with small red, orange or yellow cylindrical, uncurved flowers and long-exserted stamens and style.

Conservation status. Least Concern (Raimondo et al. 2009).

Distribution. Occurs from the Port Elizabeth and Jansenville areas in the Eastern Cape into southern KwaZulu-Natal, the Richmond area and then with a disjunct distribution in northern KwaZulu-Natal on the border with Mpumalanga (South Africa) and Eswatini (Fig. 2).

\section{Aloidendron barberae (Dyer) Klopper \& Gideon F.Sm.}

Syn. Aloe barberae Dyer.

Common names. Tree aloe (English); boomaalwyn, mikaalwyn (Afrikaans); impondondo, indlabendlazi, inkalane unkulu, umgxwala (Zulu). 


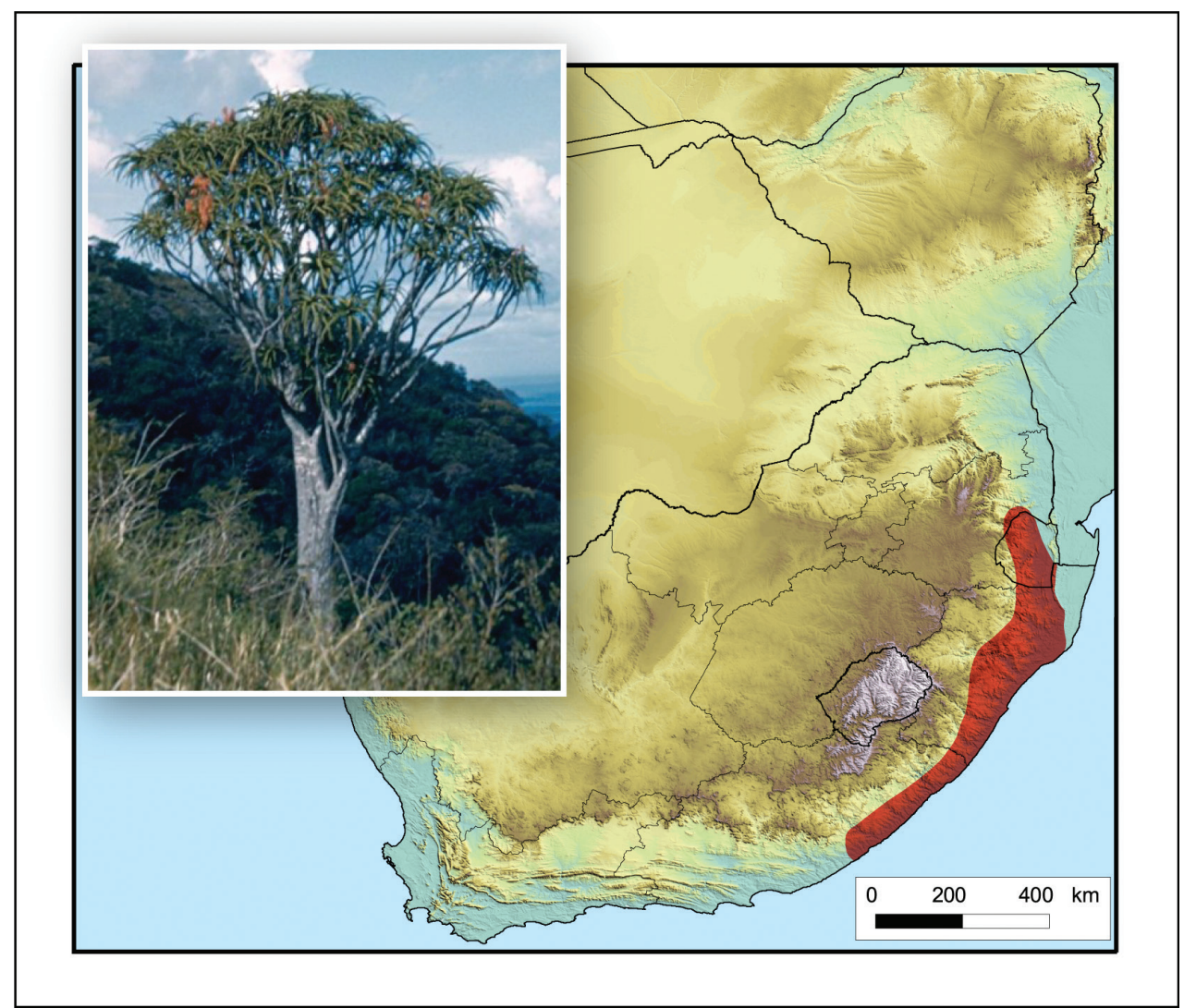

Figure 3. Aloidendron barberae. Photo: G.W. Reynolds.

Description. Arborescent plant, up to $18 \mathrm{~m}$ high. Stem $10-18 \mathrm{~m}$ high, profusely branched dichotomously and rebranched from about middle, erect, without persistent dried leaves. Leaves densely rosulate, recurved, dull green, without spots, ensiform, deeply channelled, 60-90 cm long, 7-9 cm wide at base; sheath with greenish-white marginal border; margin narrow, white, cartilaginous, with firm, horny, brownish tipped, dull white, deltoid teeth, 2-3 mm long, 10-25 mm apart. Inflorescences $0.4-$ $0.6 \mathrm{~m}$ high, erect, dichotomously 3-branched. Racemes cylindrical, slightly acuminate, 20-30 cm long, dense. Floral bracts $8-10 \mathrm{~mm}$ long, $\pm 1 \mathrm{~mm}$ wide. Pedicels 7-10 mm long. Flowers: perianth rose to rose-pink, greenish tipped, 33-37 mm long, $\pm 9 \mathrm{~mm}$ across ovary, not narrowed above ovary, widening towards middle, narrowing somewhat towards upturned mouth, cylindrical-ventricose; outer segments free almost to base; stamens exserted to $15 \mathrm{~mm}$; style exserted $15-20 \mathrm{~mm}$.

Flowering time. May-August.

Habitat. Dense, tall bush and low forest, rocky slopes of wooded valleys.

Diagnostic characters. Aloidendron barberae is one of only two large-growing tree aloes indigenous to KwaZulu-Natal. These two aloes both have dichotomously branched stems and branches that lack persistent dried leaves. Aloidendron barberae dif- 
fers from Aloidendron tongaense in being much taller (up to $18 \mathrm{~m}$ ) with more branches and having larger bright green leaves of 60-90 cm long (not dull green and 40-59 cm); their distribution ranges are also mutually exclusive. The inflorescence is also slightly taller at $0.4-0.6 \mathrm{~m}$ (not $\pm 0.35 \mathrm{~m}$ ) and 3-branched from a single point (not up to 6-branched), with longer cylindrical racemes of 20-30 cm long (not capitate and 4-6 cm), bearing straight rose-pink flowers that are 33-37 mm long (not curved yellow flowers of 47-50 mm) with stamens exserted to $15 \mathrm{~mm}$ at anthesis (not 3-5 mm).

Conservation status. Least Concern (Raimondo et al. 2009).

Distribution. Occurs in scattered localities, often in inaccessible sites (with steep gradients), in a broad coastal zone from East London in the Eastern Cape, through KwaZulu-Natal and Mpumalanga, South Africa, also in Eswatini (Fig. 3).

Notes. Aloidendron barberae is often cited as occurring in Mozambique, the latest of these being Van Jaarsveld and Judd (2015). However, an examination of available herbarium specimens at several South African and European herbaria has shown that specimens from Mozambique all represent $A$. tongaense (Walker et al. 2019b). This is supported by Burrows et al. (2018) who only treat the latter species. However, considering that $A$. barberae is common on the South African side of the Lebombo range, it may well be present in nearby southern Mozambique, which borders on the foothills of the range. Further investigation is needed to confirm whether or not $A$. barberae is present in this botanically under-explored part of Mozambique.

\section{Aloidendron tongaense (Van Jaarsv.) Klopper \& Gideon F.Sm.}

Syn. Aloe tongaensis Van Jaarsv.

Description. Tree, 4-8 m high, with rounded crown. Trunk 60-80 cm diameter at base, erect, dichotomously branched, without persistent dried leaves, with grey bark. Leaves rosulate at branch tips, spreading to recurved, dull green, without markings, leathery, ensiform, upper surface canaliculate, $40-59 \mathrm{~cm}$ long, $4.5 \mathrm{~cm}$ wide; margin with teeth, $2 \mathrm{~mm}$ long, 5-10 $\mathrm{mm}$ apart. Inflorescence $\pm 0.35 \mathrm{~m}$ tall, erect, up to 6-branched. Racemes capitate, 4-6 cm long, rather dense. Floral bracts $12-14 \mathrm{~mm}$ long, 3-4 mm wide. Pedicels $10-14 \mathrm{~mm}$ long. Flowers: perianth yellowish-orange, $47-50 \mathrm{~mm}$ long, 8-9 mm across ovary, narrowing very slightly towards mouth, cylindrical, curved; outer segments free for $10 \mathrm{~mm}$; stamens exserted 3-5 mm; style exserted to $7 \mathrm{~mm}$.

Flowering time. Mainly April-May.

Habitat. Sand forest and coastal dune forest, in warm, humid, tropical/subtropical conditions, on sandy soil.

Diagnostic characters. Aloidendron tongaense is one of only two large tree aloes indigenous to KwaZulu-Natal. These two aloes both have dichotomously branched stems that lack persistent dried leaves. Aloidendron tongaense differs from Aloidendron barberae in being a shorter tree (up to $8 \mathrm{~m}$, not up to $18 \mathrm{~m}$ ) with fewer branches and having smaller dull green leaves of 40-59 cm long (not bright green and 60- 


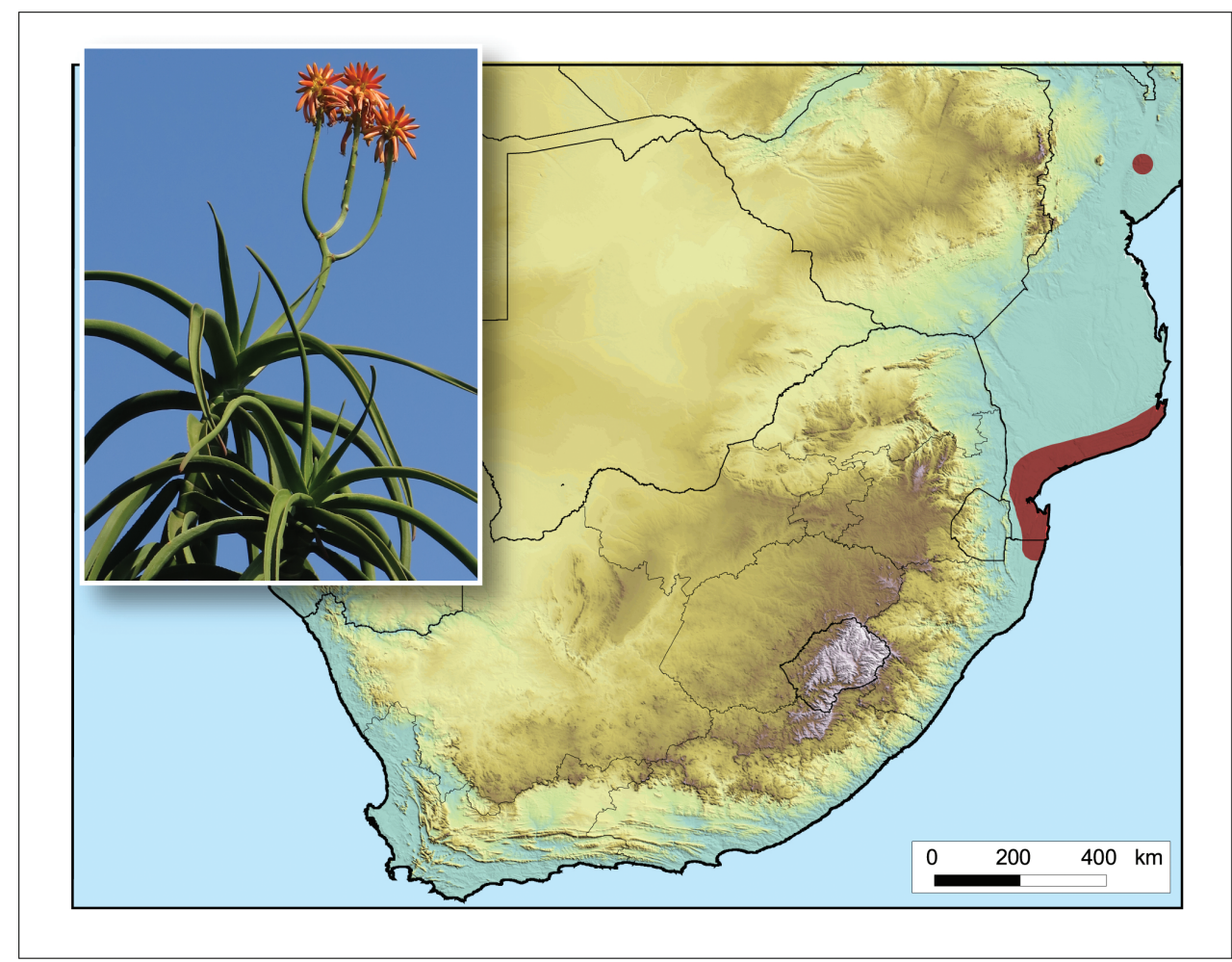

Figure 4. Aloidendron tongaense. Photo: N.R. Crouch.

$90 \mathrm{~cm}$ ). The inflorescence is also slightly shorter at $\pm 0.35 \mathrm{~m}$ (not $0.4-0.6 \mathrm{~m}$ ) and up to 6-branched (not 3-branched from a single point), with shorter capitate racemes of 4-6 cm long (not cylindrical and 20-30 cm), bearing curved yellowish-orange flowers that are 47-50 mm long (not straight rose-pink flowers of 33-37 mm) with stamens exserted 3-5 $\mathrm{mm}$ at anthesis (not up to $15 \mathrm{~mm}$ ).

Conservation status. Least Concern (Von Staden et al. 2013).

Distribution. Occurs in the sand forest and coastal dune forest at Kosi Bay in northern KwaZulu-Natal (Maputaland), South Africa and along the southern Mozambique coast as far north as Inhambane, with a known disjunct collection further north in the Cheringoma District of east-central Mozambique (Fig. 4). It is a near-endemic of the Maputaland Centre of Endemism (Van Wyk and Smith 2001).

Notes. This aloe was previously considered to be a coastal form of $A$. barberae, but was later accorded species status (Van Jaarsveld 2010). Although the protologue and subsequent literature states that the species is only known from northern KwaZuluNatal, South Africa and adjacent areas of southern Mozambique, herbarium specimens indicate that it occurs much wider in Mozambique. In fact, numerous specimens from lowland parts of Mozambique, previously regarded as $A$. barberae, have now been assigned to A. tongaense (Walker et al. 2019b). 


\section{Aristaloe aristata (Haw.) Boatwr. \& J.C.Manning}

Syn. Aloe aristata Haw.

Common names. Guinea-fowl aloe (English); tarentaalaalwyn (Afrikaans); umathithibala (Zulu).

Description. Acaulescent plants; rosettes solitary or usually suckering to form dense clumps. Leaves densely rosulate, erect to arcuate-incurved, green to grey-green, with several scattered small, white spots, more copiously spotted with spots in more or less transverse bands on lower surface, spots subtuberculate to spinulescent, soft white spines in 1 or 2 rows at apex of keel, narrowly lanceolate to deltoid, tapering to hair-like awn, leaf $8-10 \mathrm{~cm}$ long, $1-2 \mathrm{~cm}$ wide at base; margin with soft, white, cartilaginous teeth, $1-2 \mathrm{~mm}$ long, $1-2 \mathrm{~mm}$ apart at mid-leaf. Inflorescence $0.2-0.5 \mathrm{~m}$ high, erect, usually 2- to 6-branched, occasionally simple. Racemes subcapitate, 10-20 cm long, rather lax. Floral bracts $11-12 \mathrm{~mm}$ long, $4 \mathrm{~mm}$ wide. Pedicels 20-35 mm long. Flowers: perianth red on upper surface, paler below, $\pm 40 \mathrm{~mm}$ long, $\pm 7 \mathrm{~mm}$ across ovary, slightly narrowed above ovary, slightly widening towards middle, narrowing at mouth, base somewhat globose, tube slightly decurved; outer segments free for $7 \mathrm{~mm}$; stamens exserted to $1 \mathrm{~mm}$; style exserted 1-2 mm.

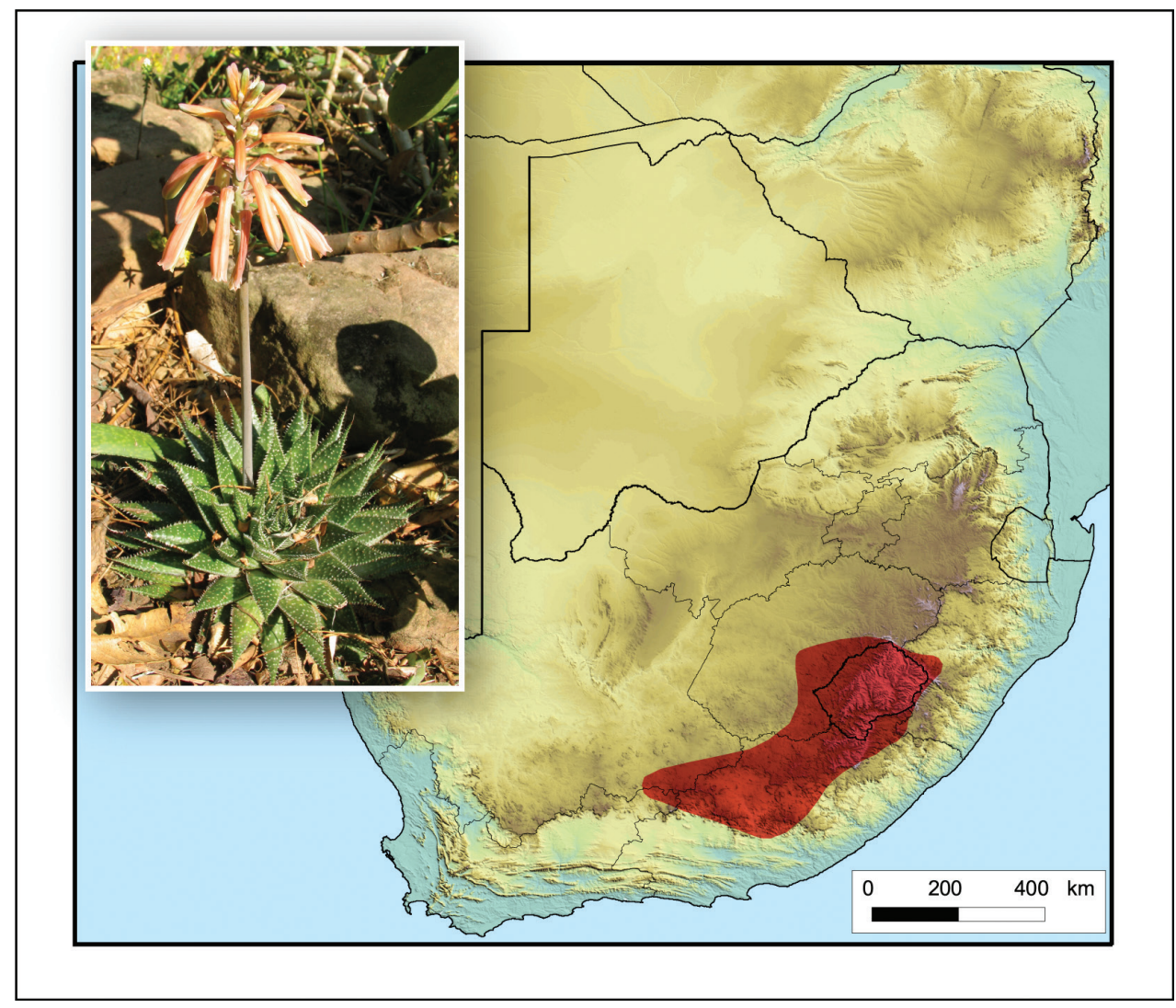

Figure 5. Aristaloe aristata. Photo: N.R. Crouch. 
Flowering time. August-October (November).

Habitat. Wide variety of habitats, including sandy to clayey soils in hot, dry karroid areas, deep shade on humus-rich soil in riverine forest and montane forest and grassland on high mountains in Lesotho.

Diagnostic characters. Aristaloe aristata can easily be distinguished from other KwaZulu-Natal aloes by being an acaulescent plant with small haworthia-like rosettes (10-15 cm diameter) that sometimes occur solitary, but more often sucker to form dense groups. The leaves $(8-10 \times 1-2 \mathrm{~cm})$ have numerous, tuberculed, white-spots with long, thin, hair-like tips on both surfaces. The inflorescence $(0.2-0.5 \mathrm{~m}$ high) is usually 2- to 6-branched or occasionally simple with the peduncle without sterile bracts. Racemes are subcapitate and rather lax. Flowers are tubular and slightly curved ( $\pm 40 \mathrm{~mm}$ long), with a basal swelling around the ovary. The uppermost (dorsal) portion of the pedicel and flower, which receive more sun, are deeper red than the paler lower (ventral) portion. This is the only South African Aloe species that resembles a member of Haworthia Duval when not in flower.

Conservation status. Least Concern (Raimondo et al. 2009).

Distribution. Widespread from Beaufort West (Western Cape) in the central Great Karoo, through the Eastern Cape and eastern Free State to south-western KwaZulu-Natal, South Africa, as well as in Lesotho (Fig. 5).

Aloe arborescens Mill. (including $A$. arborescens subsp. mzimnyati Van Jaarsv. \& A.E.van Wyk)

Common names. Krantz aloe (English); kransaalwyn (Afrikaans); inhlaba-encane, inhlazi, inkalane, inkalane-encane, umhlabana (Zulu).

Description. Much-branched shrub, 2-5 m high. Stems erect, with persistent dried leaves. Leaves densely rosulate at branch apices, spreading-recurved, dull green to grey-green, tinged reddish in dry conditions, without spots, texture smooth, lanceolateattenuate, 40-60 cm long, 5-7 cm wide at base; margin with firm, pale teeth, 3-5 mm long, 5-20 mm apart at mid-leaf; exudate pale yellow. Inflorescences $0.6-0.8 \mathrm{~m}$ high, erect, usually simple, occasionally with 1 or 2 short branches. Racemes conical to conical-cylindrical, 20-30 cm long, dense. Floral bracts 15-20 mm long, 10-12 mm wide. Pedicels $35-40 \mathrm{~mm}$ long. Flowers: perianth scarlet, often pink turning yellow at anthesis or occasionally yellow, $\pm 40 \mathrm{~mm}$ long, $7 \mathrm{~mm}$ across ovary, narrowed above ovary, widening to middle, narrowing slightly towards mouth, cylindrical-trigonous; outer segments free to base; stamens and style exserted to $5 \mathrm{~mm}$.

Flowering time. (February) June-July (August).

Habitat. Usually in pockets of rich soil on krantz edges, rocky slopes and outcrops in areas of high summer rainfall, sometimes in dense bush.

Diagnostic characters. Aloe arborescens is a much-branched shrub up to $5 \mathrm{~m}$ high, with stems rather robust (not thin and slender as in Aloiampelos tenuior) and leaves in dense rosettes at the branch apices. Leaves are greyish-green with pale yellow teeth. In- 


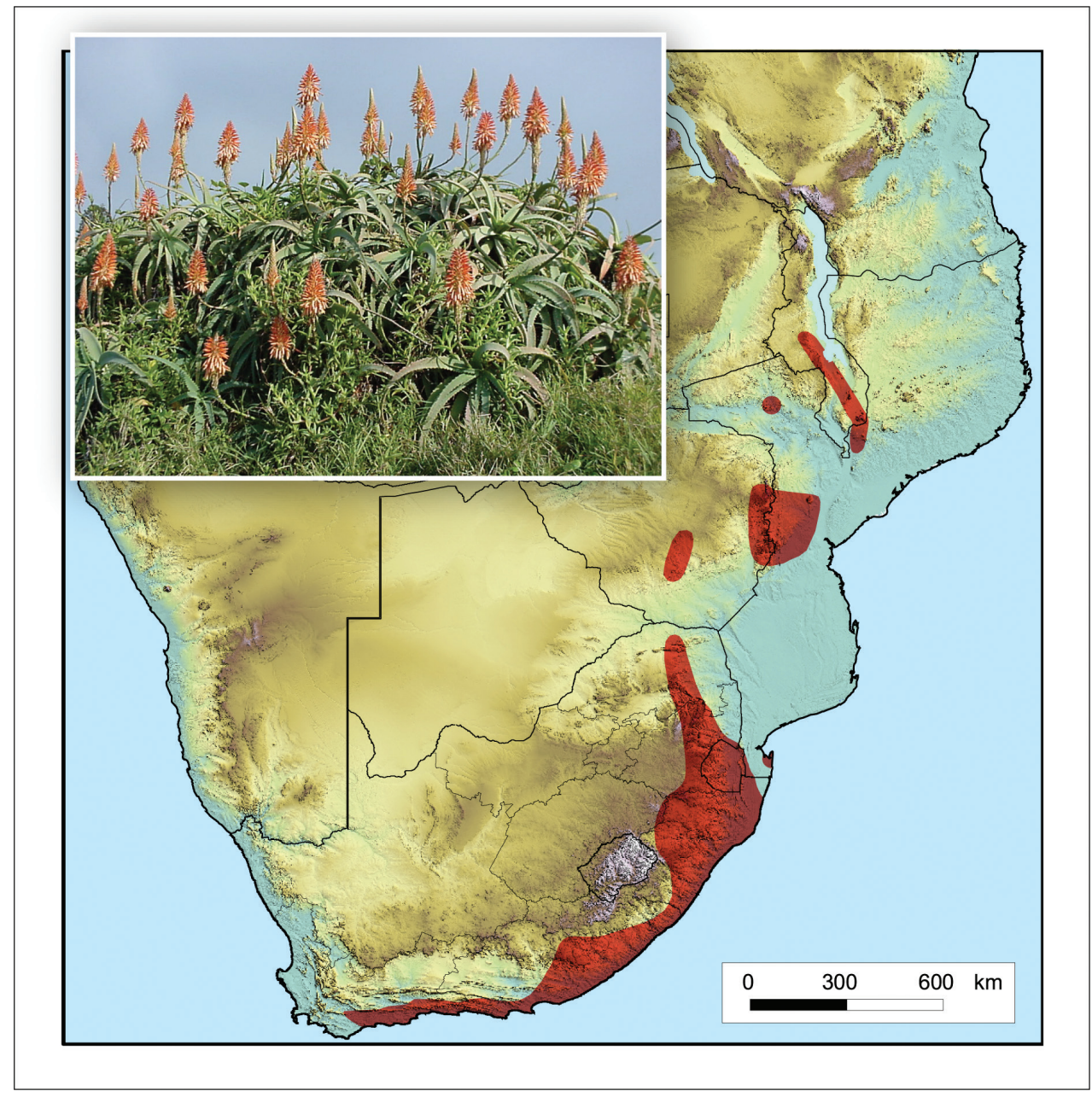

Figure 6. Aloe arborescens. Photo: G. Nichols.

florescences are usually simple with elongated conical racemes that are densely flowered. Floral bracts are large (15-20 mm long) with the pedicels twice as long $(35-40 \mathrm{~mm})$.

Conservation status. Least Concern (Raimondo et al. 2009).

Distribution. The krantz aloe is very widely distributed in south-eastern Africa and has the third widest distribution range of all Aloe species. It occurs from the Cape Peninsula (where it has arguably become naturalised), along the south and east coast of South Africa, through the Western Cape, Eastern Cape and KwaZulu-Natal and inland to Mpumalanga and Limpopo, just entering the eastern Free State, as well as further north to Mozambique and the eastern mountains of Zimbabwe and Malawi (Fig. 6). A robust form of the species has become naturalised along the European Mediterranean coast (see, for example, Smith and Figueiredo 2009).

Notes. In the past, several variations of $A$. arborescens have been afforded formal status at subspecific or varietal ranks, the most recent being $A$. arborescens subsp. mzimnyati 
Van Jaarsv. \& A.E.van Wyk, which is endemic to the lower Mzimnyati River (Buffalo River) in KwaZulu-Natal. This subspecies is distinguished by its smaller growth habit (forming a shrub of $0.50-0.75 \mathrm{~m}$ high), its smaller, slightly clavate flowers (22-25 mm long) that vary in colour (orange-red to orange to yellow) within the same population and its slightly later flowering time (July-August) (Van Jaarsveld and Van Wyk 2005). We here follow the view of Smith et al. (2012), who concluded that it is better to regard $A$. arborescens as a single variable species, pending further research and, therefore, include $A$. arborescens subsp. mzimnyati in the synonymy of the species.

\section{Aloe bergeriana (Dinter) Boatwr. \& J.C.Manning}

Syn. Chortolirion bergeriana Dinter.

Common names. Kleinaalwyn (Afrikaans).

Description. Herbaceous acaulescent perennial. Bulb usually solitary, ovoidoblong, formed by pale rosy membraneous leaves-bases. Leaves rosulate, slightly succulent, grass-like, flaccid to erect, greyish-green, once twisted, 15-29 cm long, $1-3(-5) \mathrm{mm}$ wide in middle of leaf, leaf base hairy and unspotted; margins soft, white,

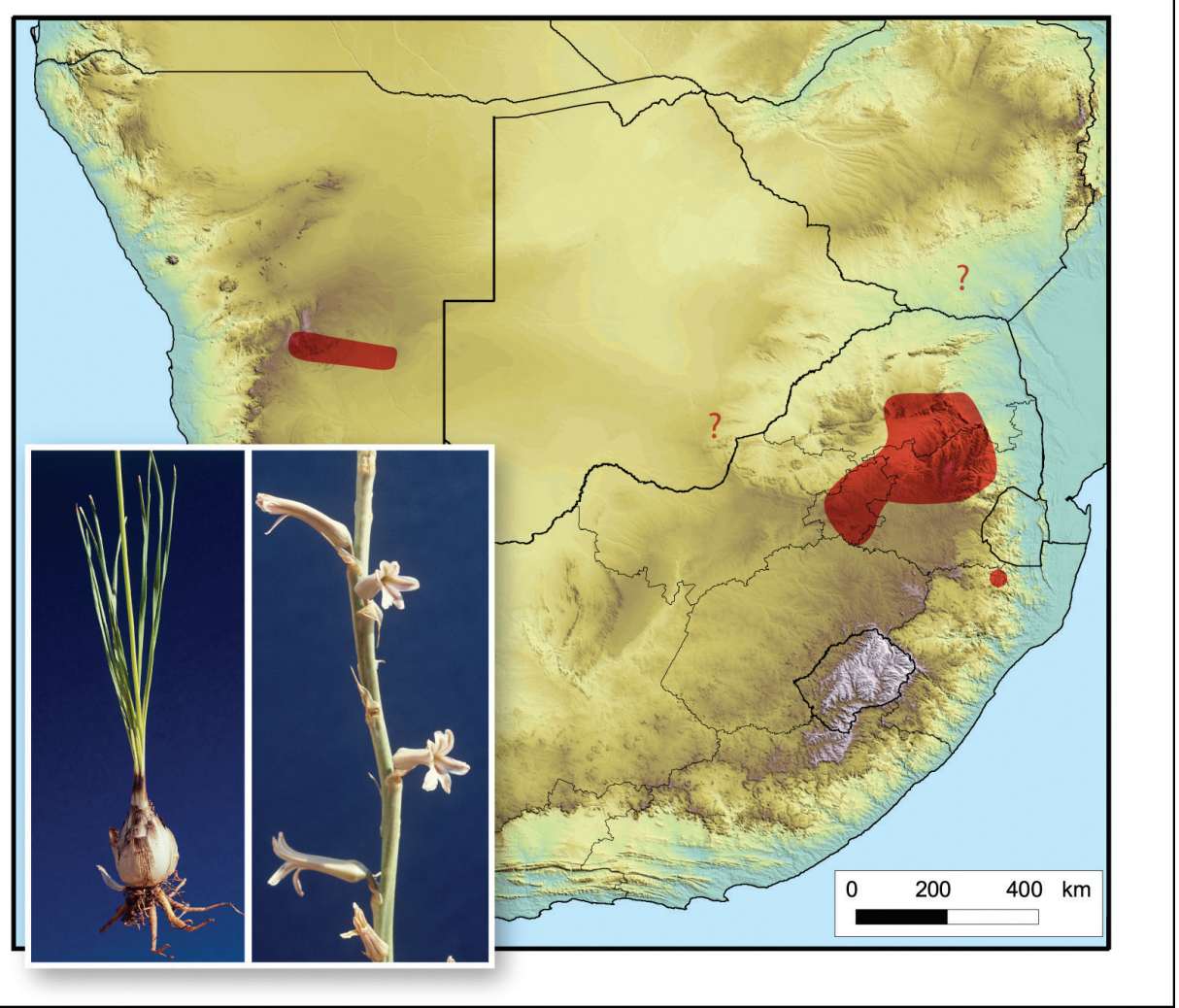

Figure 7. Aloe bergeriana. Photos: G.F. Smith. 
decurved teeth. Inflorescence $20-35 \mathrm{~cm}$ high, simple, lower sterile parts bracteate, produced when leaves are fully developed. Racemes narrowly cylindrical, lax. Floral bracts $7 \mathrm{~mm}$ long, $4 \mathrm{~mm}$ wide. Pedicels 3-4 mm long. Flowers: perianth pinkishwhite with darker keel, 14-17 mm long, very slightly narrowed above ovary, cylindrical and straight to wide open bilabiate mouth, base obtuse; outer segments free almost to base; stamens and style hardly or not exserted.

Flowering time. January-March.

Habitat. Rocky sandstone and quartzitic outcrops.

Diagnostic characters. Aloe bergeriana can be distinguished from other grass aloes in KwaZulu-Natal where the leaf bases form a subterranean bulb-like swelling (Aloe inconspicua, Aloe kniphofioides and Aloe modesta) by the very narrow leaves $(15-29 \times 0.1-0.3 \mathrm{~cm})$ that are twisted once and hairy near the unspotted base, with rosy leaf bases. It is also characterised by the lax, unbranched, cylindrical raceme with shortly pedicellate, sub-erect to horizontal, pinkish-white, darker keeled, bilabiate, unscented flowers (14-17 mm long).

Conservation status. Least Concern (Von Staden 2014a).

Distribution. Widespread but rare throughout Gauteng, Mpumalanga and Limpopo, South Africa, with records from KwaZulu-Natal in South Africa and Namibia, possibly also in Botswana and Zimbabwe (Fig. 7).

\section{Aloe boylei Baker}

Common names. Broad-leaved grass aloe (English); breëblaargrasaalwyn (Afrikaans); incothobe, isiphukuthwane, isiphuthumane, isiputhujane (Zulu).

Description. Grass aloe. Stem short, up to $0.2 \mathrm{~m}$ long, simple or with offshoots from ground level to form dense groups, erect, dried leaves not persistent. Leaves rosulate, deciduous, erect, deep green, upper surface channelled, usually without spots, sometimes lineate or with few scattered spots near base, lower surface copiously whitespotted near base, lanceolate-ensiform, 50-60 cm long, 6-9 cm wide at base; margin with soft, white teeth, 1-3 mm long, 2-5 mm apart near base; exudate clear. Inflorescence $0.4-0.6 \mathrm{~m}$ high, erect, simple. Raceme capitate, sub-corymbose or slightly conical, $10-12 \mathrm{~cm}$ long, dense. Floral bracts $20-23 \mathrm{~mm}$ long, 5-7 mm wide. Pedicels 40-45 mm long. Flowers: perianth salmon-pink, greenish tipped, 30-40 mm long, 11-12 $\mathrm{mm}$ across ovary, narrowing towards mouth, cylindrical, basally stipitate and narrowing into pedicel; outer segments almost free to base; stamens scarcely exserted or to 1-2 $\mathrm{mm}$; style exserted 2-3 $\mathrm{mm}$.

Flowering time. December-January.

Habitat. Eastern escarpment grassland, open rocky grassy hillsides.

Diagnostic characters. Aloe boylei can be distinguished from other grass aloes in KwaZulu-Natal with its unkeeled leaves that are wider than $3.5 \mathrm{~cm}$ (Aloe ecklonis, Aloe hlangapies, Aloe kraussii and Aloe neilcrouchii), by the large rosette of erect, rosulate leaves $(50-60 \times 6-9 \mathrm{~cm})$, with the upper surface usually without spots and the lower surface copiously white-spotted near the base. It is further characterised by the unbranched in- 


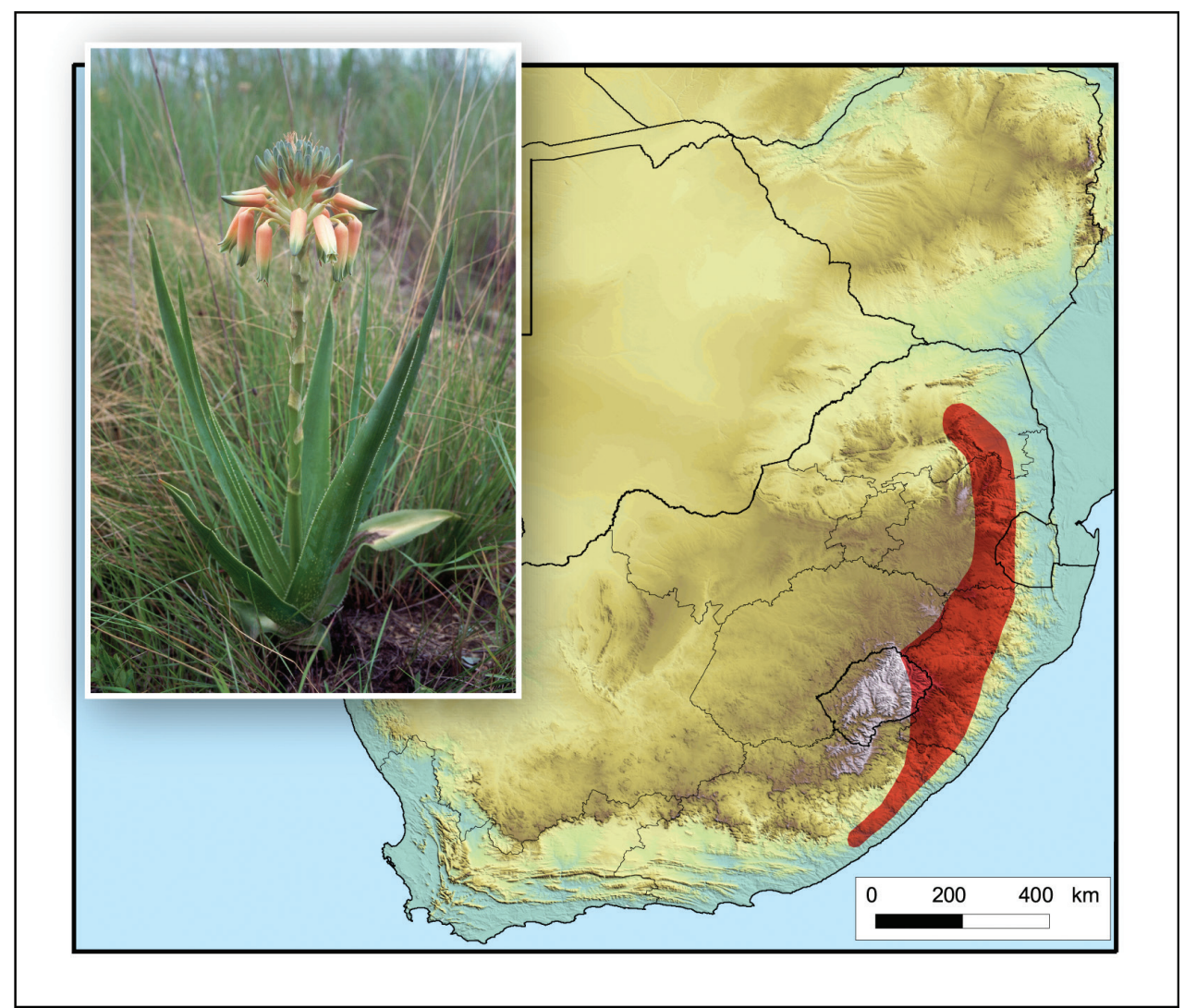

Figure 8. Aloe boylei. Photo: N.R. Crouch.

florescences (0.4-0.6 m high) that have dense, capitate, subcorymbose or slightly conical racemes (10-12 cm long) with large (30-40 mm long), salmon-pink, tubular flowers.

Conservation status. Least Concern (L. von Staden pers. comm.).

Distribution. This species is widely distributed in eastern southern Africa, occurring in the Eastern Cape, western KwaZulu-Natal, eastern Free State, Mpumalanga and Limpopo in South Africa, as well as eastern Lesotho and western Eswatini (Fig. 8).

Notes. Aloe boylei is considered by some as conspecific with Aloe ecklonis SalmDyck, together with Aloe kraussii Baker and Aloe hlangapies Groenewald (Glen and Hardy 2000; Carter et al. 2011).

\section{${ }^{\mathrm{E}}$ Aloe candelabrum A.Berger}

Common names. Candelabrum aloe (English); doringaalwyn, kandelaaraalwyn (Afrikaans); umhlaba (Zulu).

Description. Solitary, arborescent plant up to 2-4 m high. Stem simple, erect, 2-4 m high, densely covered with persistent dried leaves. Leaves densely rosulate, 


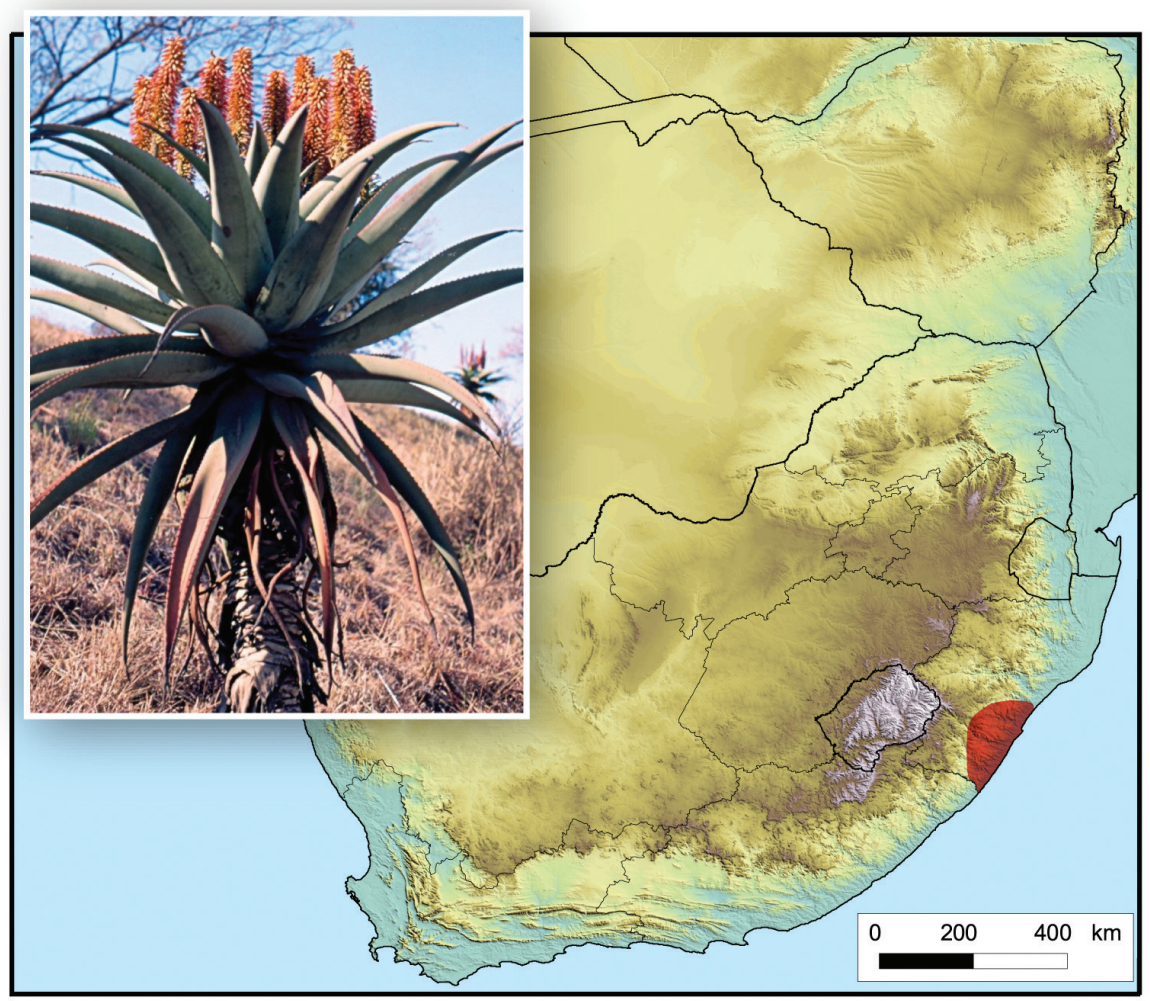

Figure 9. Aloe candelabrum. Photo: G.F. Smith.

spreading to recurved, dull green to glaucous, without spots, surfaces smooth, lanceolate-ensiform, $\pm 100 \mathrm{~cm}$ long, $15 \mathrm{~cm}$ wide at base, under surface with few spines in median line near apex, occasionally with few scattered spines; margin reddish, cartilaginous, with pungent, reddish to reddish-brown, deltoid teeth, $\pm 3 \mathrm{~mm}$ long, $15-$ $20 \mathrm{~mm}$ apart; exudate honey-coloured. Inflorescence usually single, $\pm 1 \mathrm{~m}$ high, erect, 6- to 12-branched. Racemes cylindrical, slightly acuminate, 50-80 cm long, terminal raceme, the longest and standing out higher than lateral racemes, very dense. Floral bracts $\pm 10 \mathrm{~mm}$ long, $\pm 5 \mathrm{~mm}$ wide. Pedicels $6 \mathrm{~mm}$ long. Flowers: perianth scarlet, sometimes rose-pink or orange, rarely white, $\pm 32 \mathrm{~mm}$ long, $\pm 5 \mathrm{~mm}$ across ovary, widening above ovary towards slightly upturned mouth, clavate-cylindrical, slightly ventricose; outer segments free for 16-22 mm; stamens and style exserted $20 \mathrm{~mm}$.

Flowering time. June-July.

Habitat. Thornveld and bushy places on rocky slopes and hills and undulating country.

Diagnostic characters. Aloe candelabrum differs from the other tall often singlestemmed aloes in KwaZulu-Natal (Aloe marlothii, Aloe pluridens, Aloe rupestris, Aloe spectabilis and Aloe thraskii) with branched inflorescences, by having long $( \pm 100 \times$ $15 \mathrm{~cm}$ ), spreading to recurved, deeply channelled leaves that sometimes have a few 
scattered spines on the lower surface and pungent, reddish to reddish-brown marginal teeth. The candelabra-like inflorescence is 6- to 12-branched with erect, very dense, cylindrical, slightly acuminate racemes of 50-80 cm long (the terminal raceme being longer than the lateral ones). Flowers are scarlet, sometimes rose-pink to orange, rarely white and $\pm 32 \mathrm{~mm}$ long with white inner segment tips.

Conservation status. Near-threatened. Threats include habitat loss and degradation owing to silviculture, agriculture (mainly sugarcane) and urban expansion, as well as encroachment by alien invasives and illegal harvesting (L. von Staden pers. comm.).

Distribution. More or less restricted to the valleys between the Umkhomazi and Umgeni Rivers in KwaZulu-Natal, South Africa (Fig. 9).

Notes. The Index kewensis entry (now included in International Plant Names Index, www.ipni.org) for Aloe candelabrum Tod. in Hortus Botanicus Panormitanus: 46 (1876) is wrong as no such name exists. That reference is to Agave candelabrum Tod. in Hortus Botanicus Panormitanus: 66 (1876). This agave species is probably a synonym of Agave cantala (Haw.) Roxb. ex Salm-Dyck (Figueiredo and Smith 2012). The name Aloe candelabrum A.Berger is thus legitimate and not a later homonym (Reynolds 1950) as is often reported (e.g. Govaerts 2014).

Recognition of Aloe candelabrum as distinct from Aloe ferox Mill. (Smith et al. 2016), in the synonymy of which it is sometimes included, implies that Aloe ferox, a predominantly Western and Eastern Cape species that just enters the south-western Free State and southern Lesotho, does not occur in KwaZulu-Natal.

\section{Aloe chabaudii Schönland var. chabaudii}

Common names. Chabaud's aloe (English); grysaalwyn (Afrikaans); inhlaba, inkalane (Zulu).

Description. Acaulescent plants or stem very short, procumbent; rosettes up to $0.5 \mathrm{~m}$ high, suckering or dividing to form dense groups. Leaves densely rosulate, erect or spreading, dull grey-green to glaucous green, sometimes with reddish tinge, obscurely lineate, usually without spots, sometimes with few small confluent, H-shaped, scattered spots, ovate-lanceolate, acuminate, 30-60 cm long, 6-15 cm wide at base; margin cartilaginous, narrow, greyish, with small, deltoid, pale to brownish teeth, 1-3 mm long, 5-10 mm apart; exudate clear pale yellow. Inflorescence $0.5-1.5 \mathrm{~m}$ high, erect or oblique, 6- to 12-branched, lower branches rebranching. Racemes broadly cylindrical, slightly acuminate, occasionally sub-capitate, 5-15 cm long, rather lax. Floral bracts 3-6 mm long, 1.5-4.0 mm wide. Pedicels up to 20-25 mm long, spreading. Flowers: perianth pale brick-red or bright coralpink, sometimes orange to yellow, paler at mouth, 35-40 mm long, 7-9 mm across ovary, narrowed above ovary, widening towards mouth, cylindrical-trigonous, decurved; outer segments free for $\pm 8 \mathrm{~mm}$; stamens exserted 1-2 mm; style exserted to $2 \mathrm{~mm}$.

Flowering time. April-August.

Habitat. Usually on bare rock on granite domes, at foot of granite whalebacks and outcrops or in shallow soil pockets and shady wooded slopes. Frost-sensitive. 


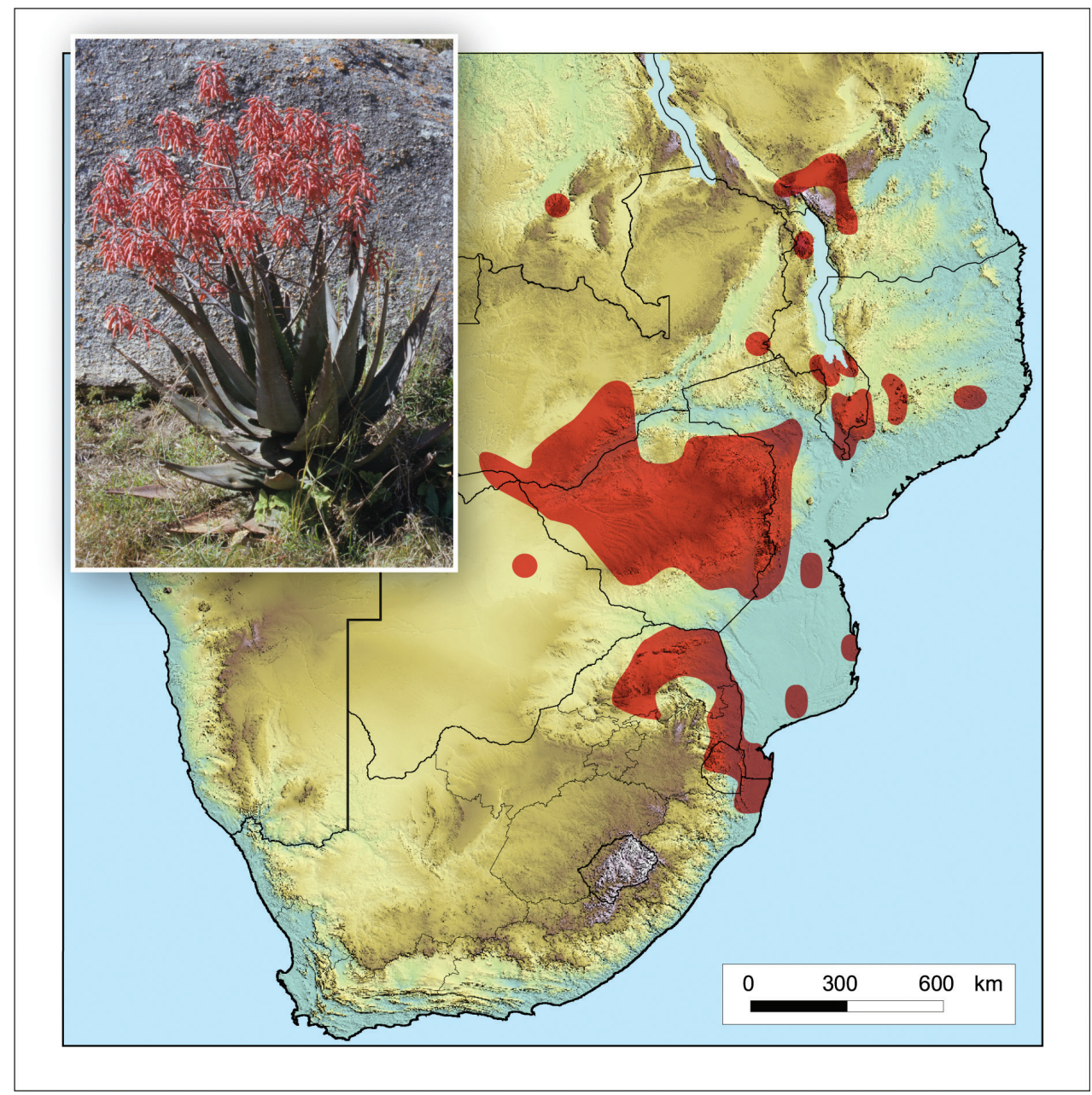

Figure 10. Aloe chabaudii var. chabaudii. Photo: M. Kimberley.

Diagnostic characters. Aloe chabaudii var. chabaudii can be distinguished from other virtually acaulescent, non-maculate aloes in KwaZulu-Natal (Aristaloe aristata, Aloe gerstneri, Aloe pratensis, Aloe reitzii var. vernalis, Aloe suprafoliata and Aloe vanbalenii) by its suckering habit that results in the establishment of dense groups of rosettes. It is further characterised by its erect to spreading, greyish-green to glaucous green leaves $(30-60 \times 6-15 \mathrm{~cm})$ with rather small closely-spaced marginal teeth. The inflorescence is erect to oblique, up to $1.5 \mathrm{~m}$ high and 6- to 12-branched with the lower branches spreading and rebranching. Floral bracts are short $(3-6 \mathrm{~mm})$ and pedicels oblique to almost horizontal (up to $25 \mathrm{~mm}$ ). Flowers are mostly reddish, 35-40 mm long and narrowed above the ovary.

Conservation status. Least Concern (Raimondo et al. 2009).

Distribution. Centre of distribution in Zimbabwe, extending north to Zambia and Malawi and south-western Tanzania, west into eastern Botswana, the Caprivi Strip of 
north-eastern Namibia, east to Mozambique and south to the Limpopo, Mpumalanga and northern KwaZulu-Natal provinces of South Africa, as well as Eswatini (Fig. 10).

Notes. One other variety is recognised in $A$. chabaudii, namely $A$. chabaudii var. mlanjeana Christian that is confined to the Mulanje Massif and hills in the Thyolo and Mulanje District, Malawi.

\section{Aloe cooperi Baker}

Common names. Cooper's aloe (English); cooperse-aalwyn (Afrikaans); isipukutwane, isiputumane, inqimindolo (Zulu).

Description. Grass aloe. Acaulescent plants or stem short, up to $0.15 \mathrm{~m}$, erect, usually simple; rosettes solitary or sometimes with offshoots at ground level to form small groups; dried leaves not persistent. Leaves distichous, sometimes spirally twisted to rosulate in old plants, erect, deciduous, green, usually without spots on upper surface, with copious white spots at base on lower surface, obscurely lineate, narrowly long-deltoid, distinctly keeled, V-shaped in cross section, 40-80 cm long, 2.5-6.0 cm wide at base; margin with firm, white teeth, 1-2 mm long, 1-2 mm apart at mid-leaf; exudate clear. Inflorescences 0.4 $1.0 \mathrm{~m}$ high, erect, simple. Raceme broadly conical, 10-20 cm long, dense. Floral bracts 20-35 mm long, 10 mm wide. Pedicels 30-60 mm long. Flowers: perianth salmon-pink near base, green tipped, 25-40 mm long, $\pm 12 \mathrm{~mm}$ across ovary, narrowing towards mouth, roundly trigonous, basally stipitate and narrowing into pedicel; outer segments free almost to base; stamens not exserted or exserted 1-2 mm; style exserted to $5 \mathrm{~mm}$.

Flowering time. December-February.

Habitat. Regularly occurs in marshy places. Grows also in well-drained habitats, often amongst rocks on grassy hillsides.

Diagnostic characters. Aloe cooperi is distinguished from other grass aloes in KwaZulu-Natal with strongly keeled leaves (Aloe myriacantha and Aloe sharoniae) by the inflorescence $(0.4-1.0 \mathrm{~m}$ high) that can sometimes be shorter than the distichous leaves (40-80 cm long). Leaves have copious white spots near the base on the lower surface and a toothed margin. Flowers are salmon-pink near the base, green tipped and 25-40 mm long, with the mouth not bilabiate or upturned. Floral bracts are flat and not clasping the pedicel (as in Aloe sharoniae).

Conservation status. Least Concern, but declining. Threats include habitat transformation owing to commercial silvicultural and agricultural practices, as well as overgrazing and alien invasives (Raimondo et al. 2009).

Distribution. Occurs mainly in KwaZulu-Natal and Mpumalanga, just entering the eastern Free State, the southeast of Limpopo and the northern part of the Eastern Cape in South Africa, also widespread in Eswatini and just entering Lesotho and Mozambique (Fig. 11).

Notes. In recent years, Aloe cooperi has become very popular in South Africa in large-scale landscaping, for example of industrial sites. Unlike several other grass and slender aloes, that do not thrive beyond their natural geographical distribution ranges, most forms of Aloe cooperi are relatively easy in cultivation. 


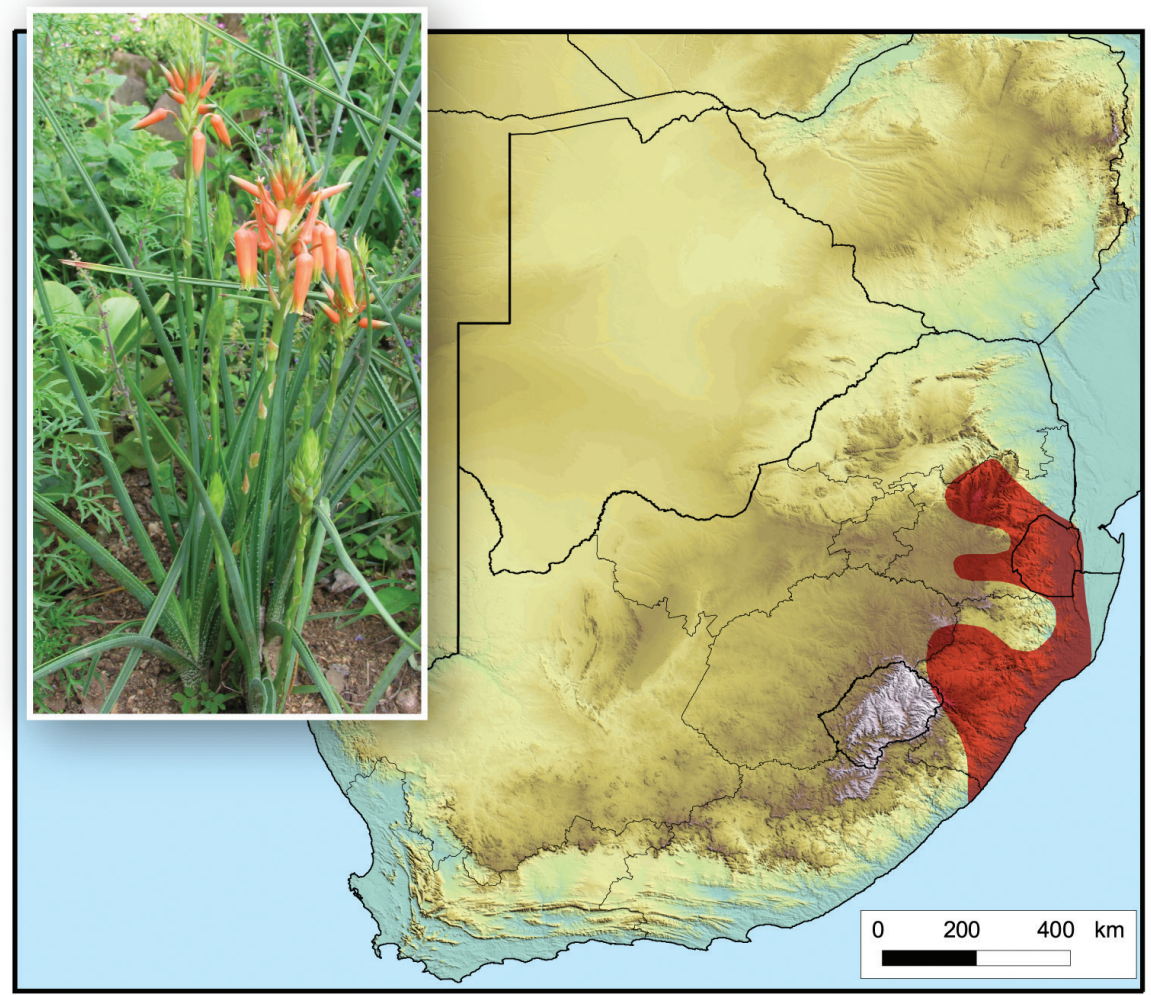

Figure I I. Aloe cooperi. Photo: N.R. Crouch.

\section{${ }^{\mathrm{NE}}$ Aloe dewetii Reynolds}

Common names. De Wet's aloe (English); dewetse-aalwyn (Afrikaans).

Description. Acaulescent plants, $0.5-0.8 \mathrm{~m}$ high; rosettes solitary, erect, can be over $1 \mathrm{~m}$ in diameter. Leaves densely rosulate, speading, dull glossy green, upper surface with numerous dull white, elongate, spots, irregularly scattered or sometimes in irregular undulating transverse bands, lower surface without spots, obscurely lineate, lanceolate-attenuate, 36-50 cm long, 7-13 cm wide at base; margin prominent, horny, brown, with pungent, deltoid, stout, brown teeth, up to $10 \mathrm{~mm}$ long, $10-15 \mathrm{~mm}$ apart; exudate clear. Inflorescence up to 2-3 m high, erect, 8- to 12-branched from about middle. Racemes cylindrical-acuminate, up to $40 \mathrm{~cm}$ long, $\pm 7 \mathrm{~cm}$ wide, lax, terminal raceme the longest. Floral bracts $\pm 20 \mathrm{~mm}$ long, $3 \mathrm{~mm}$ wide. Pedicels $8-15 \mathrm{~mm}$ long. Flowers: perianth dull scarlet with a bloom, 35-42 mm long, up to $14 \mathrm{~mm}$ across ovary, abruptly constricted above ovary to form distinct globose basal swelling, enlarging towards mouth, slightly decurved; outer segments free for $6 \mathrm{~mm}$; stamens exserted to $3 \mathrm{~mm}$; style exserted 1-2 mm.

Flowering time. February-March. 


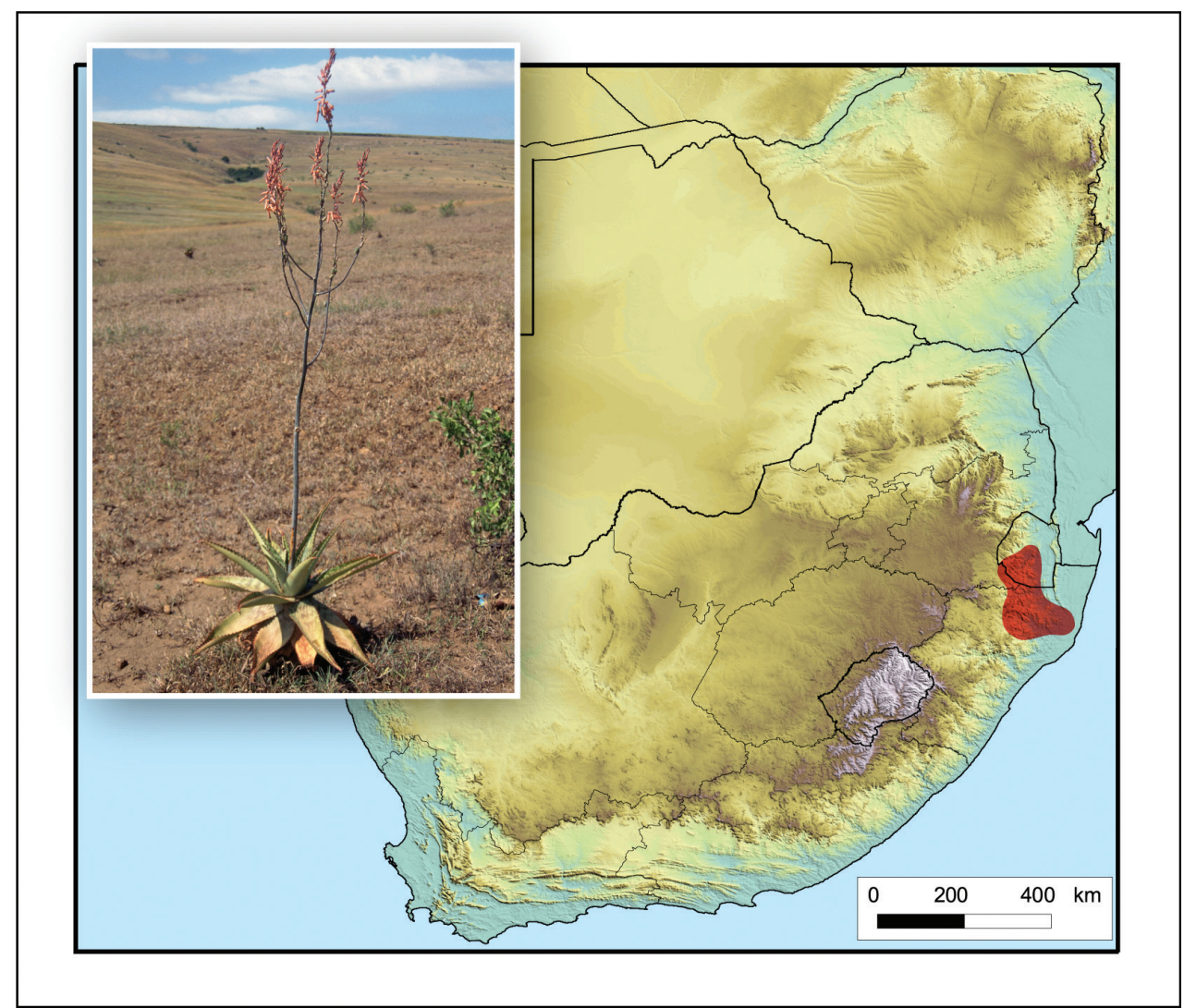

Figure I2. Aloe dewetii. Photo: N.R. Crouch.

Habitat. Windswept, gently sloping open grassland in midlands of the province on heavy soils, in areas with fairly cold winters and high rainfall with a summer maximum.

Diagnostic characters. Aloe dewetii can be distinguished from other maculate aloes in KwaZulu-Natal (Aloe maculata subsp. maculata, Aloe mudenensis, Aloe parvibracteata, Aloe prinslooi, Aloe pruinosa, Aloe suffulta, Aloe umfoloziensis, Aloe vanrooyenii and Aloe viridiana) by the spreading leaves $(36-50 \times 7-13 \mathrm{~cm})$ that have a peculiar glossy appearance and a most pronounced horny, brown margin with extra-large, pungent teeth of up to $10 \mathrm{~mm}$ long. Leaves are spotted on the upper surface, while the lower surface is without spots and obscurely lineate. The 8- to 12-branched and rebranched inflorescences are the tallest of all the maculates (up to 2-3 $\mathrm{m}$ high) and have widelyspreading branches and long cylindrical, lax racemes (up to $40 \mathrm{~cm}$ long). Pedicels are $8-15 \mathrm{~mm}$ long. Flowers are dull scarlet with a bloom, 35-42 $\mathrm{mm}$ long and with a large globose basal swelling (up to $14 \mathrm{~mm}$ diameter).

Conservation status. Least Concern (Raimondo et al. 2009).

Distribution. Limited to northern KwaZulu-Natal and southern Mpumalanga in South Africa, as well as Eswatini (Fig. 12). 


\section{${ }^{\mathrm{NE}}$ Aloe dominella Reynolds}

Description. Grass aloe, $0.3-0.4 \mathrm{~m}$ high. Stem up to $0.15 \mathrm{~m}$, branched, suckering to form clumps, erect, with persistent dried leaves. Leaves rosulate, stiffly erect, dull green, upper surface without spots, lower surface with numerous small white spots near base, narrowly linear-lanceolate, attenuate, $7-35 \mathrm{~cm}$ long, $0.2-1.0 \mathrm{~cm}$ wide, widening to $\pm 25 \mathrm{~mm}$ at sheathing base; margin very narrow, white, cartilaginous, with firm white teeth, 0.5-1.0 mm long, 2-5 mm apart; exudate clear. Inflorescence 0.25-0.40 m high, erect, simple. Raceme capitate, $\pm 4 \mathrm{~cm}$ long, $\pm 8 \mathrm{~cm}$ wide, rather dense. Floral bracts up to $15 \mathrm{~mm}$ long, 3-4 mm wide. Pedicels 13-20 mm long. Flowers: perianth lemon-yellow, 13-18 mm long, 4-5 mm across ovary, widening slightly towards mouth, cylindrical-trigonous, slightly clavate; outer segments free to base; stamens exserted 3-4 $\mathrm{mm}$; style exserted to $7 \mathrm{~mm}$.

Flowering time. June-October.

Habitat. Wedged between rocks in short grassland, often on steep, dry, rocky slopes.

Diagnostic characters. Aloe dominella can be distinguished from other grass aloes in KwaZulu-Natal with unkeeled leaves that are usually narrower than $3.5 \mathrm{~cm}$ and that lack a bulb-like underground swelling (Aloe linearifolia, Aloe micracantha,

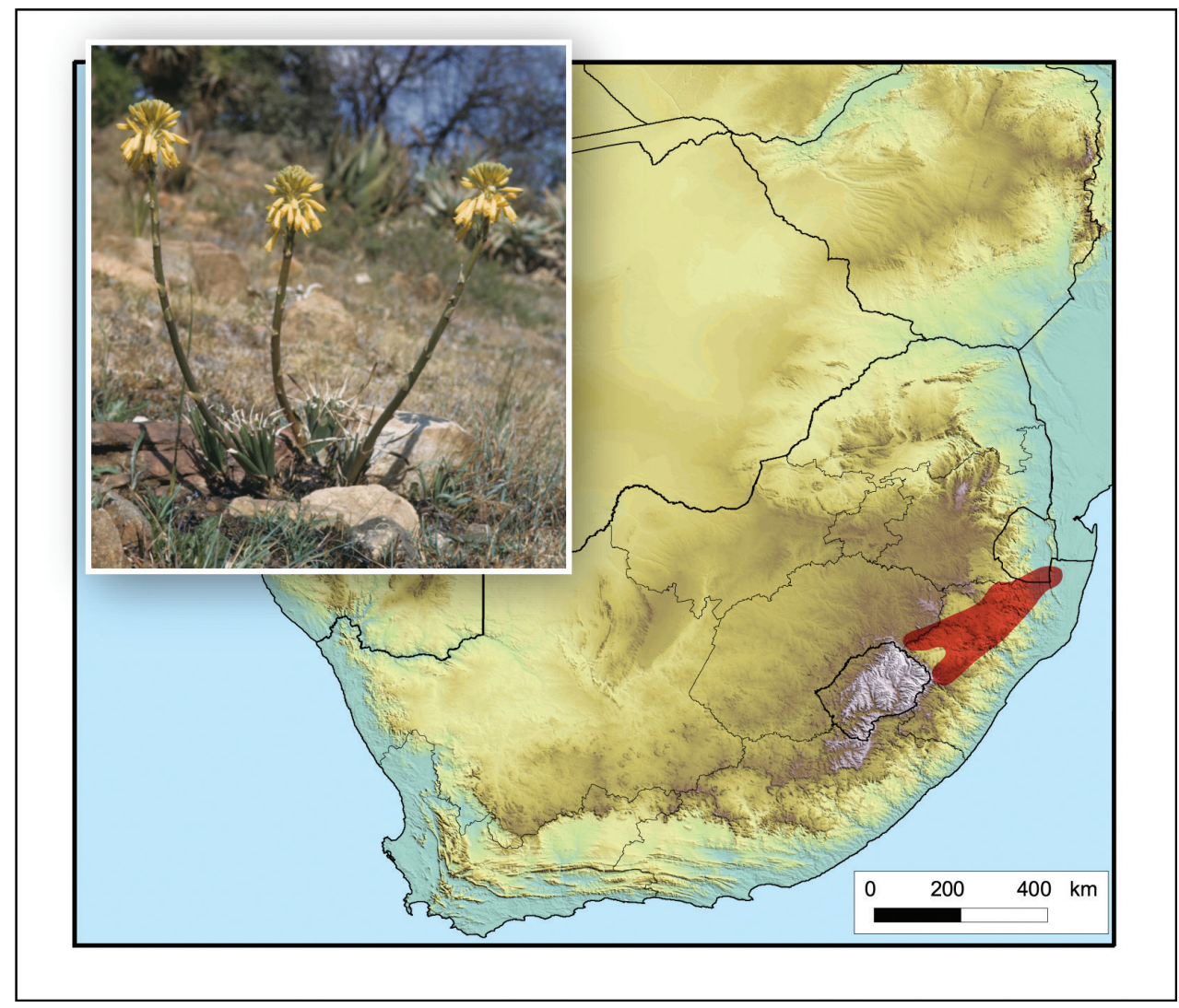

Figure I3. Aloe dominella. Photo: SANBI, PRE Slide Collection. 
Aloe minima, Aloe nicholsii, Aloe parviflora and Aloe saundersiae), by the rosulate, very narrow leaves $(7-35 \times 0.2-1.0 \mathrm{~cm})$ that are stiffly erect in small tufts. The dull green leaves have numerous small white spots near the base on the lower surface. It is also characterised by the unbranched inflorescences $(0.25-0.40 \mathrm{~m}$ high) with short, yellow flowers (13-18 mm long) that are carried in rather dense capitate racemes. Pedicels are 13-20 mm long. Rosettes are in groups.

Conservation status. Near-threatened. Threats include overgrazing, alien invasives and poor recruitment owing to too frequent fires (Raimondo et al. 2009).

Distribution. Confined to the central highlands of KwaZulu-Natal in South Africa, from Estcourt to Vryheid; just entering southern Eswatini (Fig. 13).

\section{Aloe ecklonis Salm-Dyck}

Common names. Ecklon's aloe (English); ecklonse-aalwyn, vlei-aalwyn (Afrikaans); isipukutwane, isiphuthumane (Zulu).

Description. Grass aloe. Acaulescent plants or stem very short; rosettes solitary or in small groups. Leaves rosulate, deciduous, erectly spreading, dull green, without

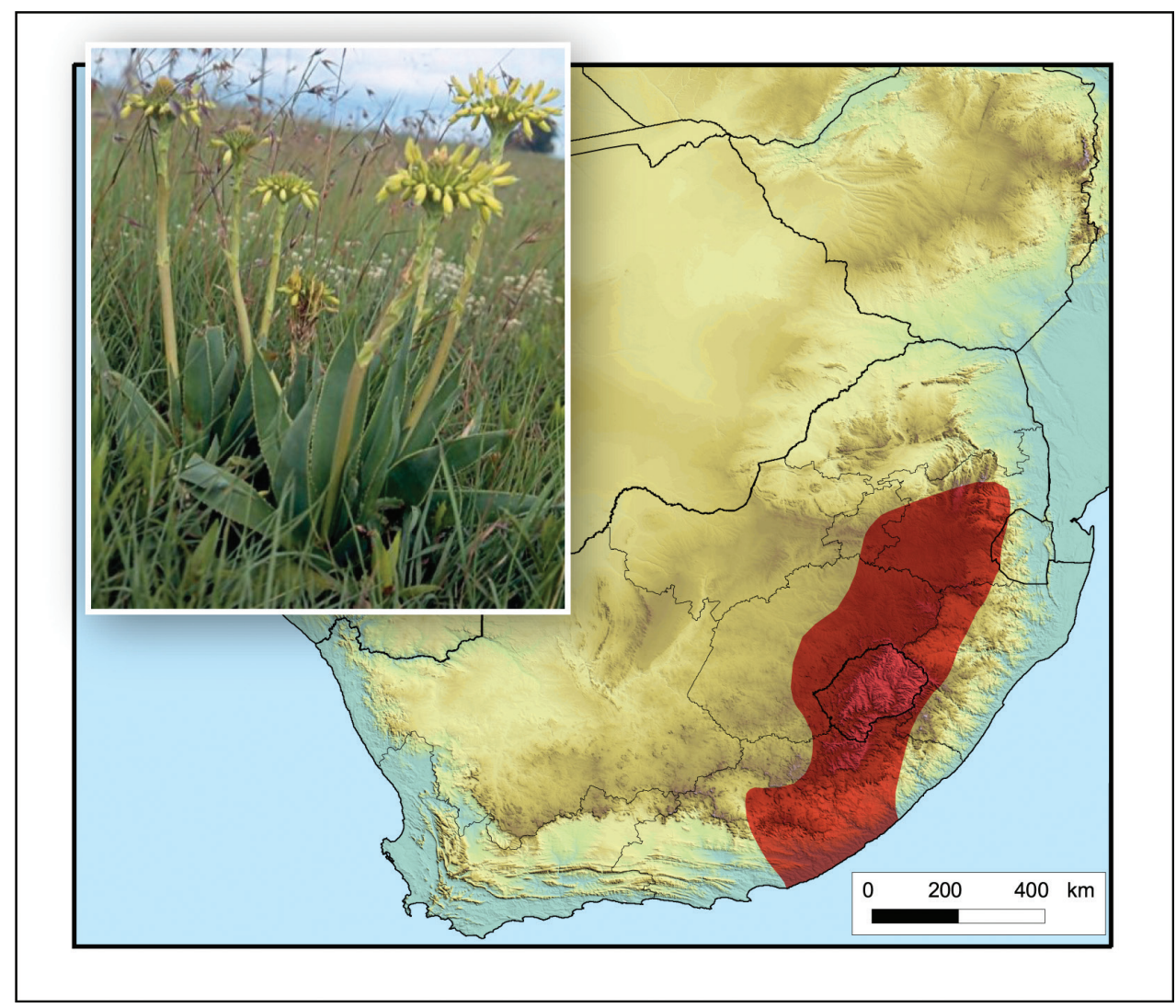

Figure I4. Aloe ecklonis. Photo: R.R. Klopper. 
spots, sometimes with few small, white spots near base on lower surface, lanceolate-attenuate, 30-40 cm long, 3-10 cm wide at base; margin with firm, white, deltoid teeth, 1-3 mm long, 3-5 mm apart; exudate clear. Inflorescences $0.38-0.50 \mathrm{~m}$ high, erect, simple. Raceme broadly capitate, somewhat corymbose, $\pm 5 \mathrm{~cm}$ long, dense. Floral bracts $10-15 \mathrm{~mm}$ long, 3-9 mm wide. Pedicels $30-40 \mathrm{~mm}$ long. Flowers: perianth yellow to red, usually salmon pink, 20-24(-40) $\mathrm{mm}$ long, $\pm 7 \mathrm{~mm}$ across ovary, markedly swollen in middle, narrowing towards slightly upturned mouth, basally stipitate and narrowing into pedicel, cylindrical trigonous; outer segments free almost to base; stamens exserted to $3 \mathrm{~mm}$; style exserted to $5 \mathrm{~mm}$.

Flowering time. November-February.

Habitat. Usually on heavy clay soils which pack hard on drying. Flat to undulating grassland, rarely on rocky slopes.

Diagnostic characters. Aloe ecklonis can be distinguished from other grass aloes in KwaZulu-Natal with unkeeled leaves that are wider than $3.5 \mathrm{~cm}$ (Aloe boylei, Aloe hlangapies, Aloe kraussii and Aloe neilcrouchii), by the large rosettes of erectly spreading, rosulate leaves $(30-40 \times 3-10 \mathrm{~cm})$, that sometimes have a few small, white spots near the base on the lower surface. It is further characterised by the unbranched inflorescences $(0.38-0.50 \mathrm{~m}$ high) that have dense, broadly capitate, somewhat corymbose racemes ( $\pm 5 \mathrm{~cm}$ long) with short [20-24(-40) $\mathrm{mm}$ long], yellow to red or usually salmon-pink flowers that are markedly swollen in the middle.

Conservation status. Least Concern (Raimondo et al. 2009).

Distribution. This species is the most widely distributed grass aloe in southern Africa, occurring along the Great Escarpment in the Eastern Cape, KwaZulu-Natal, eastern Free State, Gauteng and Mpumalanga, South Africa, as well as in Lesotho and western Eswatini (Fig. 14).

Note. Aloe ecklonis is highly variable across its range.

\section{${ }^{\mathrm{E}}$ Aloe gerstneri Reynolds}

Common names. Gerstner's aloe (English); bergaalwyn (Afrikaans); isihlabane (Zulu).

Description. Acaulescent plants or stem short; rosettes solitary, erect, $0.4-0.7 \mathrm{~m}$ high. Leaves densely rosulate, arcuate-erect, dull grey-green, without spots, texture smooth, lanceolate-ensiform, 40-60 cm long, 6-12 cm wide at base, lower surface sometimes with few spines in median line near apex (can be copiously spiny on both surfaces in young plants); margin not distinctly coloured, with isolated, pungent, deltoid, pale brown teeth from white sub-tuberculate base, $4 \mathrm{~mm}$ long, $10-15 \mathrm{~mm}$ apart; exudate honey-coloured. Inflorescence 1.0-1.3 m high, erect, simple in young plants, 1to 3-branched from below middle in mature plants. Racemes cylindrical, slightly acuminate, up to $36 \mathrm{~cm}$ long, 6-7 cm wide, very dense; buds and flowers pendent. Floral bracts $18 \mathrm{~mm}$ long, $5 \mathrm{~mm}$ wide. Pedicels $5 \mathrm{~mm}$ long. Flowers: perianth reddish-orange in bud, flowers yellowish-orange, $24-30 \mathrm{~mm}$ long, $\pm 7 \mathrm{~mm}$ across ovary, narrowing slightly towards mouth, cylindrical-ventricose, slightly clavate, mouth slightly upturned; outer segments free for $15-17 \mathrm{~mm}$; stamens exserted to $13 \mathrm{~mm}$; style exserted to $14 \mathrm{~mm}$. 


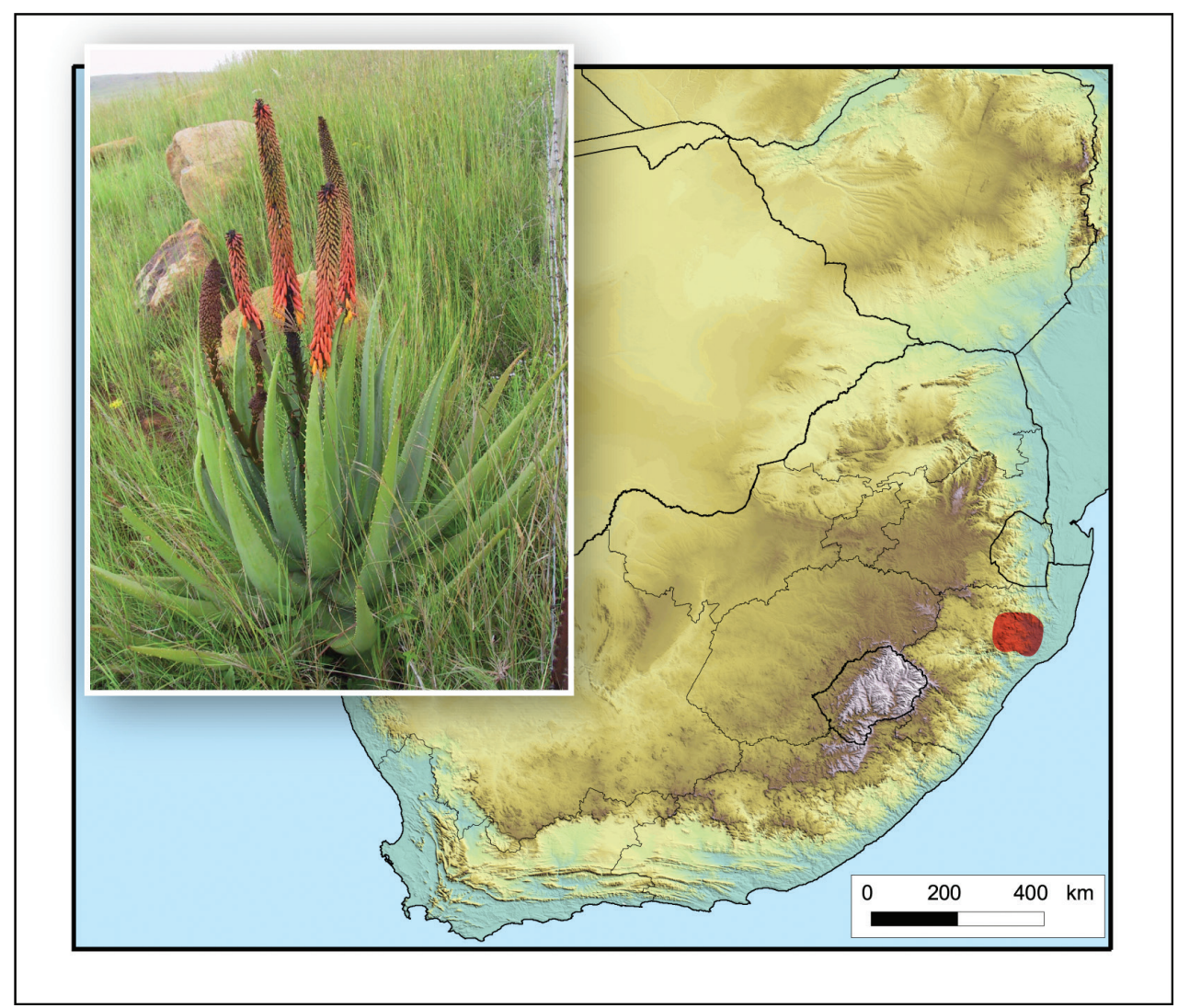

Figure I5. Aloe gerstneri. Photo: E. van Wyk.

Flowering time. February-March.

Habitat. Rocky slopes in grassland in areas with cold winters and reasonably high rainfall, on granite or quartzite formations.

Diagnostic characters. Aloe gerstneri can be distinguished from other virtually acaulescent, non-maculate aloes in KwaZulu-Natal (Aristaloe aristata, Aloe chabaudii var. chabaudii, Aloe pratensis, Aloe reitzii var. vernalis, Aloe suprafoliata and Aloe vanbalenii) by the very dense racemes (up to $36 \times 6-7 \mathrm{~cm}$ ) with short erect pedicels $(5 \mathrm{~mm})$. Flowers are yellowish-orange, 24-30 mm long, tubular and straight, pointing downwards and almost pressed against the stalk, with conspicuously exserted stamens and style. Leaves can be copiously spiny on both surfaces in young plants, but mature leaves $(40-60 \times 6-12 \mathrm{~cm})$ are without surface prickles (sometimes with spines on median line of lower surface), arcuate erect, dull grey-green and with pungent marginal teeth on a distinctive white base.

Conservation status. Endangered. Threats include habitat degradation owing to erosion caused by overgrazing and subsistence farming (Raimondo et al. 2009, L. von Staden pers. comm.).

Distribution. Restricted to a small area in northern KwaZulu-Natal, South Africa (Fig. 15). 


\section{${ }^{\mathrm{NE}}$ Aloe hlangapies Groenew.}

Description. Grass aloe. Acaulescent plants or stem short, up to $0.15 \mathrm{~m}$; rosettes usually solitary or suckering to form small groups; with persistent dried leaves. Leaves distichous, deciduous, erect to spreading, dull green, upper surface usually without spots, sometimes sparingly spotted, lower surface usually copiously whitespotted near base, lorate-acuminate, $35-50 \mathrm{~cm}$ long, $5-6 \mathrm{~cm}$ wide; margin with soft, white teeth, $\pm 0.5 \mathrm{~mm}$ long, $5-15 \mathrm{~mm}$ apart; exudate clear. Inflorescence $\pm 0.5 \mathrm{~m}$ high, erect, simple. Raceme capitate, up to $7 \mathrm{~cm}$ long, $9-10 \mathrm{~cm}$ wide, dense. Floral bracts $15 \mathrm{~mm}$ long, $7 \mathrm{~mm}$ wide. Pedicels $\pm 25 \mathrm{~mm}$ long. Flowers: perianth apricotyellow, only rarely red or yellow, greenish tipped, 28-30 mm long, $8-10 \mathrm{~mm}$ across ovary, slightly widening towards middle, narrowing towards mouth, base tapering into pedicel, straight, cylindrical; outer segments free for $23-25 \mathrm{~mm}$; stamens and style exserted to $1 \mathrm{~mm}$.

Flowering time. October-November.

Habitat. Damp, low-lying grassland and on grassy slopes.

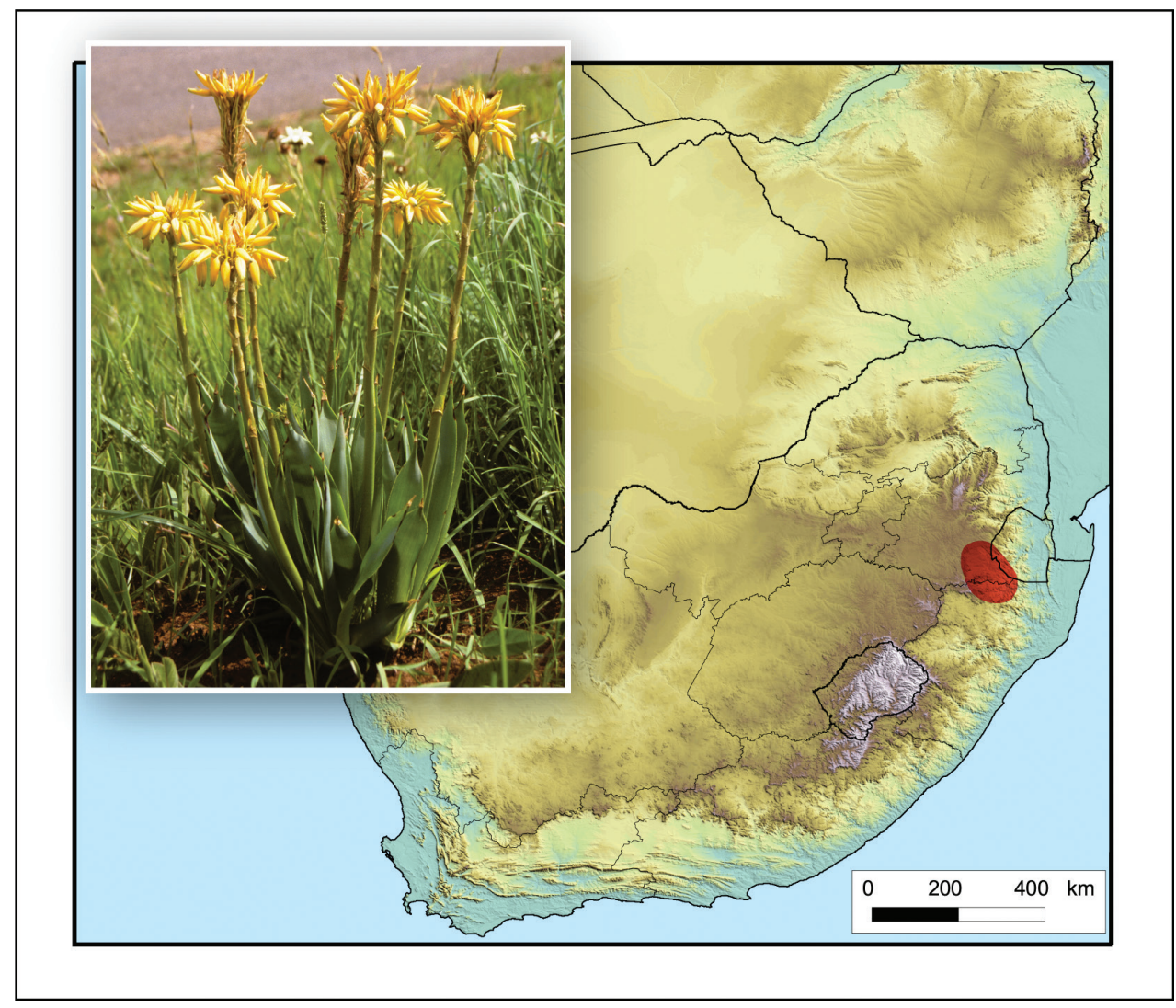

Figure I6. Aloe hlangapies. Photo: J.E. Burrows. 
Diagnostic characters. Aloe hlangapies can be distinguished from other grass aloes in KwaZulu-Natal with unkeeled leaves that are wider than $3.5 \mathrm{~cm}$ (Aloe boylei, Aloe ecklonis, Aloe kraussii and Aloe neilcrouchii), by the rosette of erect to spreading, distichous leaves $(35-50 \times 5-6 \mathrm{~cm})$, with the upper surface usually without spots and the lower surface usually copiously white-spotted near the base. It is further characterised by the unbranched inflorescences ( $\pm 0.5 \mathrm{~m}$ high) that have dense, capitate racemes (up to $7 \mathrm{~cm}$ long) with relatively long $(28-30 \mathrm{~mm}$ long), usually apricot-yellow and greenish tipped, tubular flowers.

Conservation status. Vulnerable. Threats include habitat loss owing to silviculture, agriculture and urban expansion, as well as overgrazing and alien invasives. There is also a potential threat from coal mining (L. von Staden pers. comm.).

Distribution. Only known from the area on the border between KwaZulu-Natal and Mpumalanga in South Africa and just entering south-western Eswatini (Fig. 16).

Notes. Near Wakkerstroom and Volksrust in KwaZulu-Natal, Aloe hlangapies merges into intermediates with Aloe ecklonis Salm-Dyck (Reynolds 1950).

\section{${ }^{\mathrm{E}}$ Aloe inconspicua Plowes}

Description. Grass aloe. Acaulescent plants, rosettes solitary, erect, with old persistent leaf bases forming a subterranean ovoid bulb-like swelling. Leaves rosulate, erect, deciduous, dark green, upper surface without spots, lower surface with narrow elongate white spots in basal half, narrowly linear, acuminate, $10-20 \mathrm{~cm}$ long, $0.3-0.4 \mathrm{~cm}$ wide, dilating below ground to $3 \mathrm{~cm}$; margin narrow, translucent, with soft translucent teeth, $0.5 \mathrm{~mm}$ long, 2-4 mm apart. Inflorescence $\pm 0.15 \mathrm{~m}$ high, erect, simple. Raceme narrowly triangular to cylindrical, $\pm 7 \mathrm{~cm}$ long, $2 \mathrm{~cm}$ wide, very dense. Floral bracts 13-15 mm long. Pedicels absent. Flowers: perianth green, $15 \mathrm{~mm}$ long, narrowing slightly towards slightly bilabiate mouth, cylindrical-trigonous; outer segments free to base; stamens exserted to $1 \mathrm{~mm}$; style not exserted.

Flowering time. November.

Habitat. In sparse short grass in areas of dry, low-altitude, thorny, open woodland. Grows in the transition zone between open grassland and valley bushveld. Shale and sandstone. Hot summers, but can be very cold in winter.

Diagnostic characters. Aloe inconspicua can be distinguished from other grass aloes in KwaZulu-Natal where the leaf bases form a subterranean bulb-like swelling (Aloe bergeriana, Aloe kniphofioides and Aloe modesta), by the very narrow leaves $(10-20 \times 0.3-0.4 \mathrm{~cm})$ that are heavily spotted on the lower surface and with soft transluscent marginal teeth. It is also characterised by the very dense, unbranched, cylindrical raceme $( \pm 7 \mathrm{~cm}$ long) with sessile, suberectly spreading, green, slightly bilabiate, unscented flowers (15 mm long).

Conservation status. Endangered. Threats include habitat degradation owing to overgrazing, subsistence farming and urban expansion (Raimondo et al. 2009).

Distribution. Only known from the Bushmans River catchment between Weenen and Estcourt in KwaZulu-Natal, South Africa (Fig. 17). 


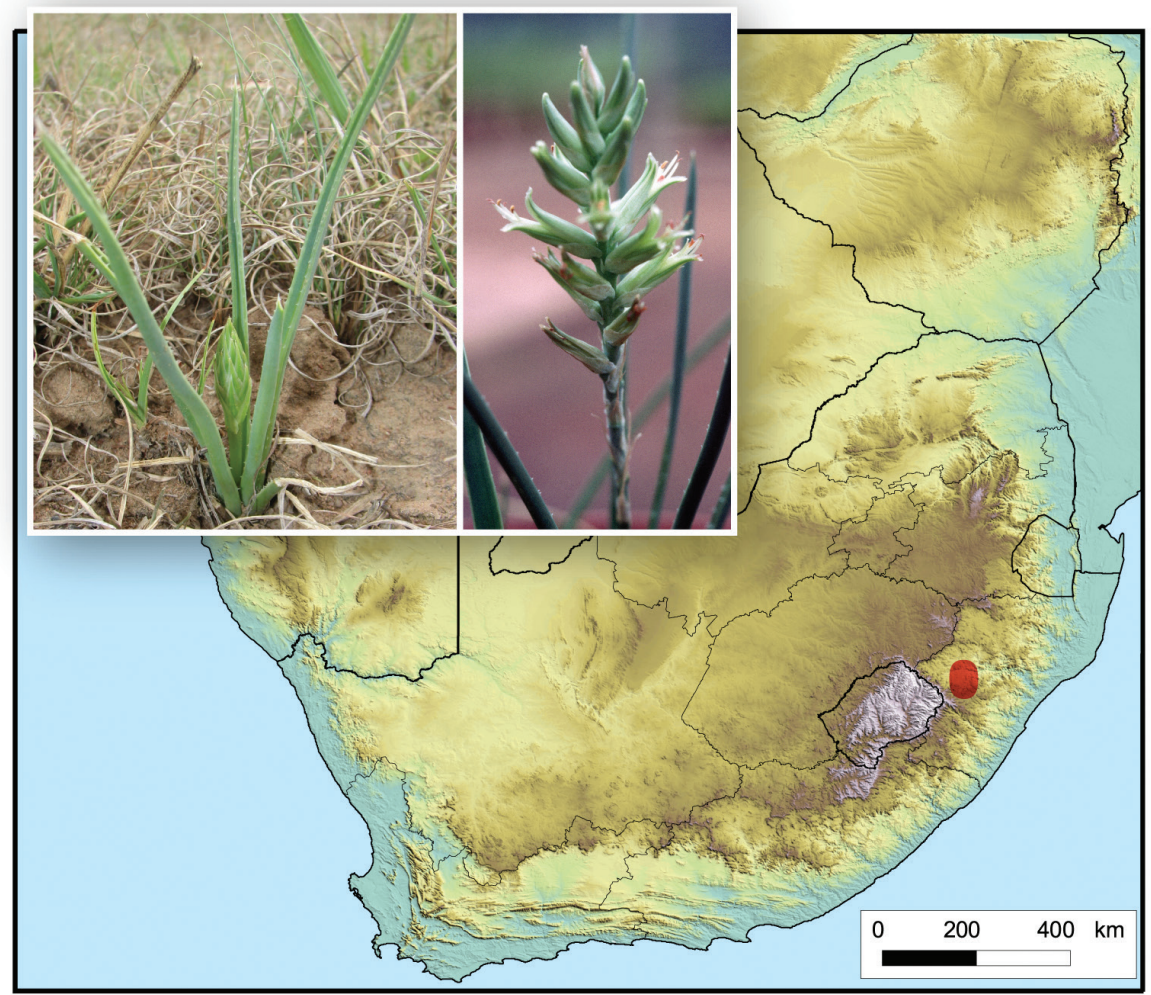

Figure I7. Aloe inconspicua. Photos: P. Joffe (flowers), E. van Wyk (plant).

\section{Aloe kniphofioides Baker}

Common names. Grass aloe (English); grasaalwyn (Afrikaans).

Description. Grass aloe. Acaulescent plants; rosettes solitary, leaf bases forming bulb-like underground swelling. Leaves rosulate, erect, green, without spots, narrowly linear, $20-40 \mathrm{~cm}$ long, $0.6-0.7 \mathrm{~cm}$ wide, dilating below ground-level to $2.0-3.0 \mathrm{~cm}$ wide; margin entire or minutely dentate, with small, white teeth, $\pm 0.7 \mathrm{~mm}$ long, 1-2 mm apart, more crowded lower down; exudate clear. Inflorescence up to 0.30$0.55 \mathrm{~m}$ high, erect, simple. Raceme cylindrical, $10-15 \mathrm{~cm}$ long, very lax, few-flowered. Floral bracts $15-22 \mathrm{~mm}$ long, 4-7 mm wide. Pedicels $12-18 \mathrm{~mm}$ long. Flowers: perianth pale pink to scarlet, green-tipped, 30-50 mm long, base rounded, 6-7 mm across ovary, not narrowed above ovary, cylindrical, slightly curved; outer segments free for 6-8 $\mathrm{mm}$; stamens and style not or very shortly exserted to $1 \mathrm{~mm}$.

Flowering time. October-November.

Habitat. Grassland in reasonably high rainfall areas. Rather heavy, stone-free soils. 


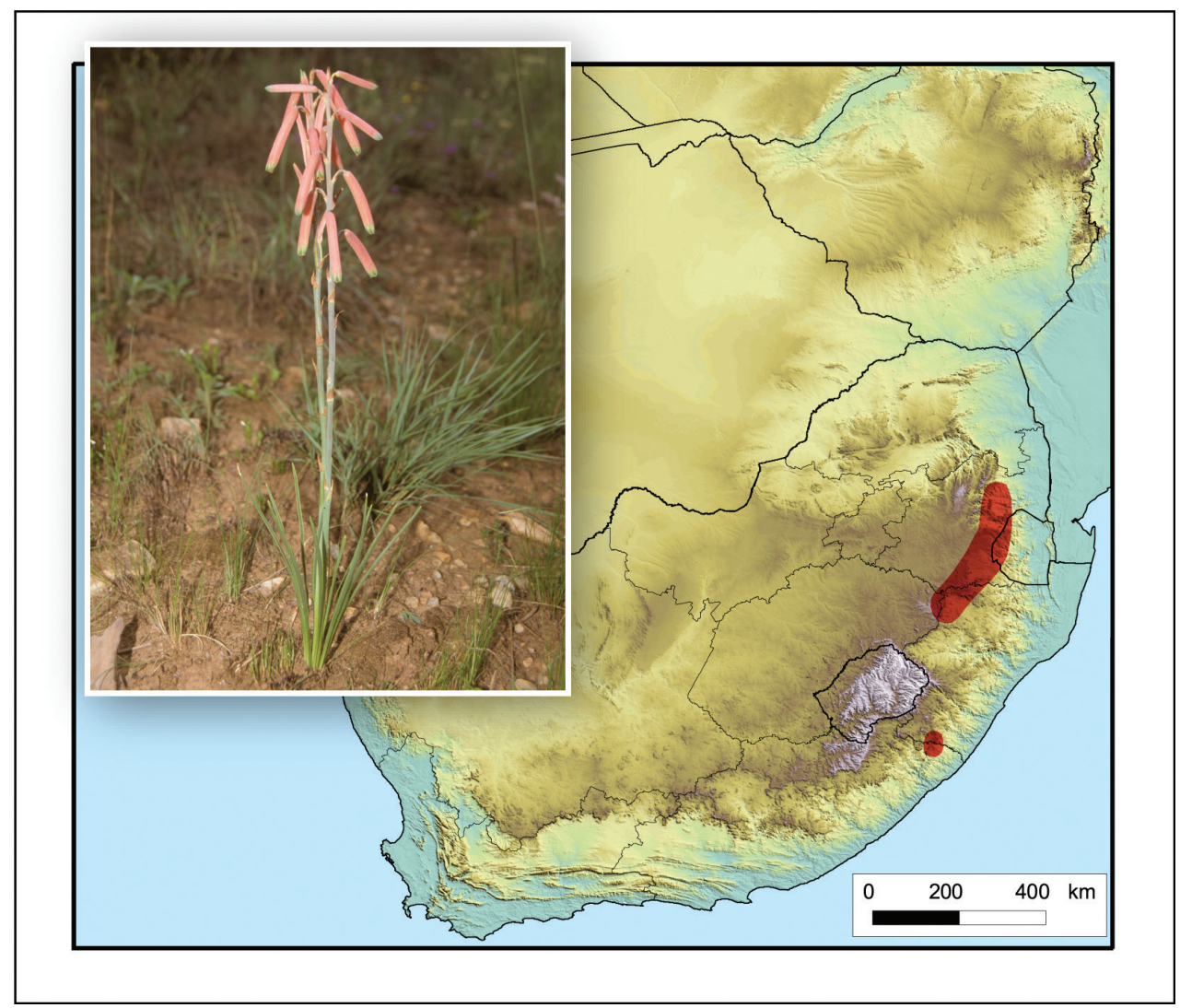

Figure 18. Aloe kniphofioides. Photo: J.E. Burrows.

Diagnostic characters. Aloe kniphofioides can be distinguished from other grass aloes in KwaZulu-Natal where the leaf bases form a subterranean bulb-like swelling (Aloe bergeriana, Aloe inconspicua and Aloe modesta), by the long, narrow, bright red, unscented flowers (30-50 mm long) that are pendent in a very lax, unbranched, cylindrical raceme (10-15 cm long), with pedicels $12-18 \mathrm{~mm}$ long. The narrow leaves $(20-40 \times$ $0.6-0.7 \mathrm{~cm}$ ) are usually without spots and with or without minute white marginal teeth.

Conservation status. Near-threatened. Threats include habitat transformation and degradation owing to mining, commercial afforestation and alien invasives, as well as a loss of pollinators and poor fire management leading to poor recruitment (Raimondo et al. 2009, L. von Staden pers. comm.).

Distribution. Widely but sparsely distributed. This species has a disjunct distribution: it occurs in the Kokstad area on the border of KwaZulu-Natal and the Eastern Cape province; and then along the Great Escarpment in northern KwaZulu-Natal, Mpumalanga and just entering the eastern Free State, South Africa, as well as in Eswatini (Fig. 18). 


\section{${ }^{\mathrm{E}}$ Aloe kraussii Baker}

Common names. Broad-leaved yellow grass aloe (English); isipukutwane, isiputumane (Zulu).

Description. Grass aloe. Acaulescent plants or stem very short, dried leaves not persistent; rosettes solitary or suckering to form small groups. Leaves distichous or sub-distichous, becoming rosulate in old plants, deciduous, erectly spreading, dull green, usually without spots, lower surface sometimes with few white spots near base, broadly linear-acuminate, $\pm 30-40 \mathrm{~cm}$ long, 3.5-5.0 cm wide; margin extremely narrow, white, cartilaginous, with minute white teeth; exudate clear. Inflorescence 0.35$0.40 \mathrm{~m}$ high, erect, simple. Raceme capitate, somewhat corymbose, $\pm 3 \mathrm{~cm}$ long, $\pm 10 \mathrm{~cm}$ wide, dense. Floral bracts up to $15 \mathrm{~mm}$ long, $5 \mathrm{~mm}$ wide. Pedicels up to $35 \mathrm{~mm}$ long. Flowers: perianth lemon-yellow to yellow, green-tipped, 16-18 mm long, $\pm 6 \mathrm{~mm}$ across ovary, narrowing towards slightly upturned mouth, base tapering into pedicel, straight, cylindrical; outer segments free almost to base; stamens exserted to $3 \mathrm{~mm}$; style exserted to $5 \mathrm{~mm}$.

Flowering time. November-February.

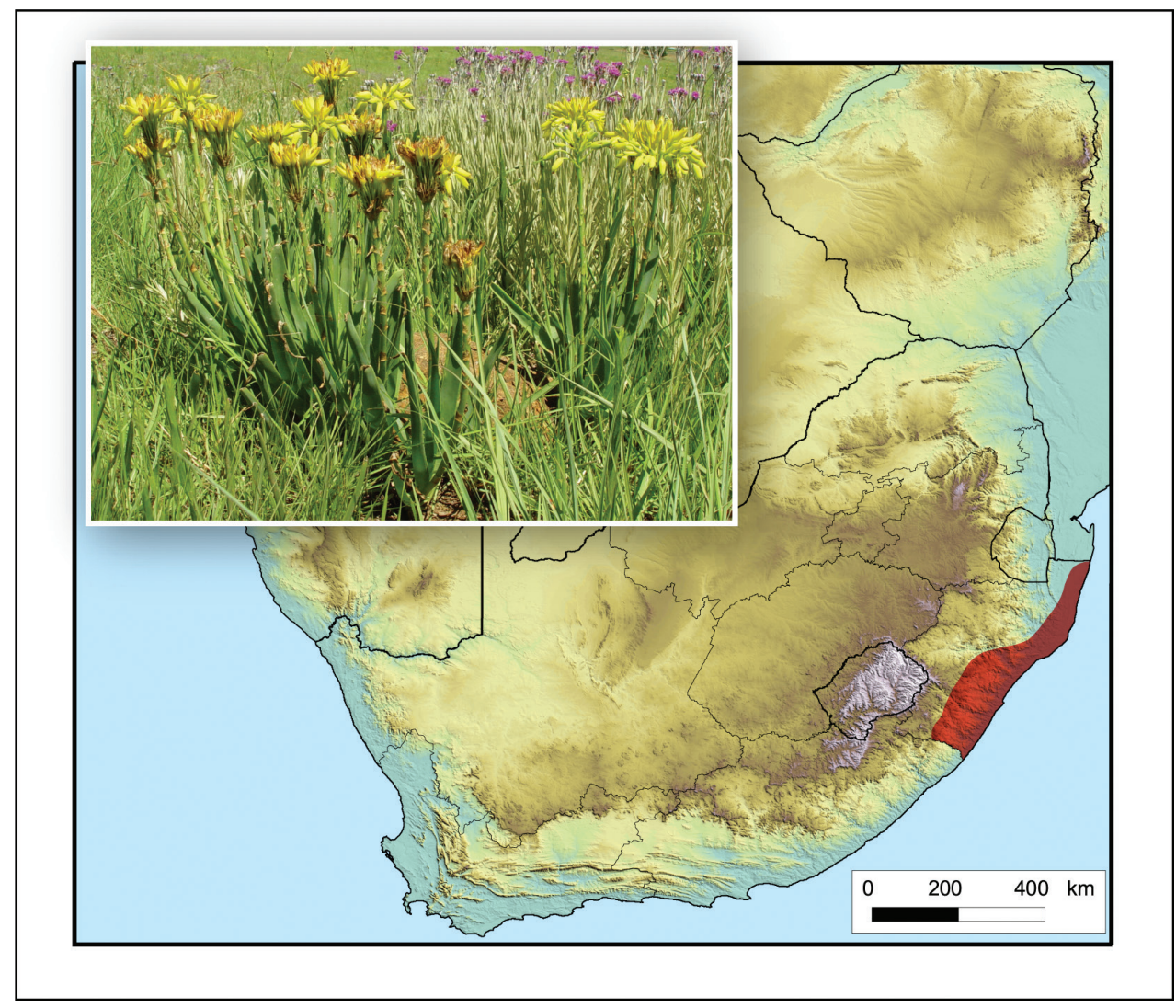

Figure 19. Aloe kraussii. Photo: G. Nichols. 
Habitat. Damp places in sandy soil or on stony slopes of grassy hillsides in the mistbelt of the KwaZulu-Natal midlands.

Diagnostic characters. Aloe kraussii can be distinguished from other grass aloes in KwaZulu-Natal with unkeeled leaves that are wider than $3.5 \mathrm{~cm}$ (Aloe boylei, Aloe ecklonis, Aloe hlangapies and Aloe neilcrouchii), by the rosettes of erectly spreading, distichous or sub-distichous leaves $( \pm 30-40 \times 3.5-5.0 \mathrm{~cm})$, that sometimes have a few white spots near the base on the lower surface. It is further characterised by the unbranched inflorescences $(0.35-0.40 \mathrm{~m}$ high) that have dense, capitate and somewhat corymbose racemes ( $\pm 3 \mathrm{~cm}$ long) with small (16-18 mm long), yellow, rather straight flowers.

Conservation status. Endangered. Threats include habitat loss and degradation owing to silviculture, agiculture (mainly sugarcane) and urban expansion, as well as alien invasives (L. von Staden pers. comm.). It is one of the rarer of the grass aloes owing to habitat loss (Craib 2005).

Distribution. Confined to the coastal areas of KwaZulu-Natal, South Africa, where it is still fairly common (Fig. 19).

Notes. Aloe kraussii is considered by some to be a low-altitude form of Aloe ecklonis Salm-Dyck (Carter et al. 2011).

\section{${ }^{\mathrm{NE}}$ Aloe linearifolia A.Berger}

Common names. Dwarf yellow grass aloe (English); inkuphuyana (Zulu).

Description. Grass aloe, up to $\pm 0.3 \mathrm{~m}$ high. Acaulescent plants or stem very short, usually simple, occasionally 1- or 2-branched at ground level, erect. Leaves usually distichous, rarely rosulate, erect to erectly spreading, deciduous, green, with copious white and brown spots near base on lower surface, linear, $\pm 25 \mathrm{~cm}$ long, $0.5-1.0 \mathrm{~cm}$ wide, basal portion dilating and becoming amplexicaul; margin usually minutely dentate near base, teeth up to $0.5 \mathrm{~mm}$, up to $4 \mathrm{~mm}$ apart, without teeth towards tip; exudate clear. Inflorescence $0.20-0.35 \mathrm{~m}$ high, erect, simple. Racemes capitate, $\pm 2 \mathrm{~cm}$ long, dense. Floral bracts 10-14 mm long, 4-7 mm wide. Pedicels $12-15 \mathrm{~mm}$ long. Flowers: perianth greenish-yellow to yellow, $\pm 12 \mathrm{~mm}$ long, $\pm 4.5 \mathrm{~mm}$ across ovary, base tapering into pedicel, not narrowed above ovary, mouth slightly upturned, cylindrical-trigonous; outer segments free almost to base; stamens exserted 0-2 mm; style exserted 1-2 mm.

Flowering time. January-February (March).

Habitat. Damp places in open sunny situations in stony grassveld or on grassy slopes, often on rocky outcrops.

Diagnostic characters. Aloe linearifolia can be distinguished from other grass aloes in KwaZulu-Natal with unkeeled leaves that are usually narrower than $3.5 \mathrm{~cm}$ and that lack a bulb-like underground swelling (Aloe dominella, Aloe micracantha, Aloe minima, Aloe nicholsii, Aloe parviflora and Aloe saundersiae), by the distichous, erect to erectly spreading, long and narrow, green leaves $( \pm 25 \times 0.5-1.0 \mathrm{~cm})$, with copious white 


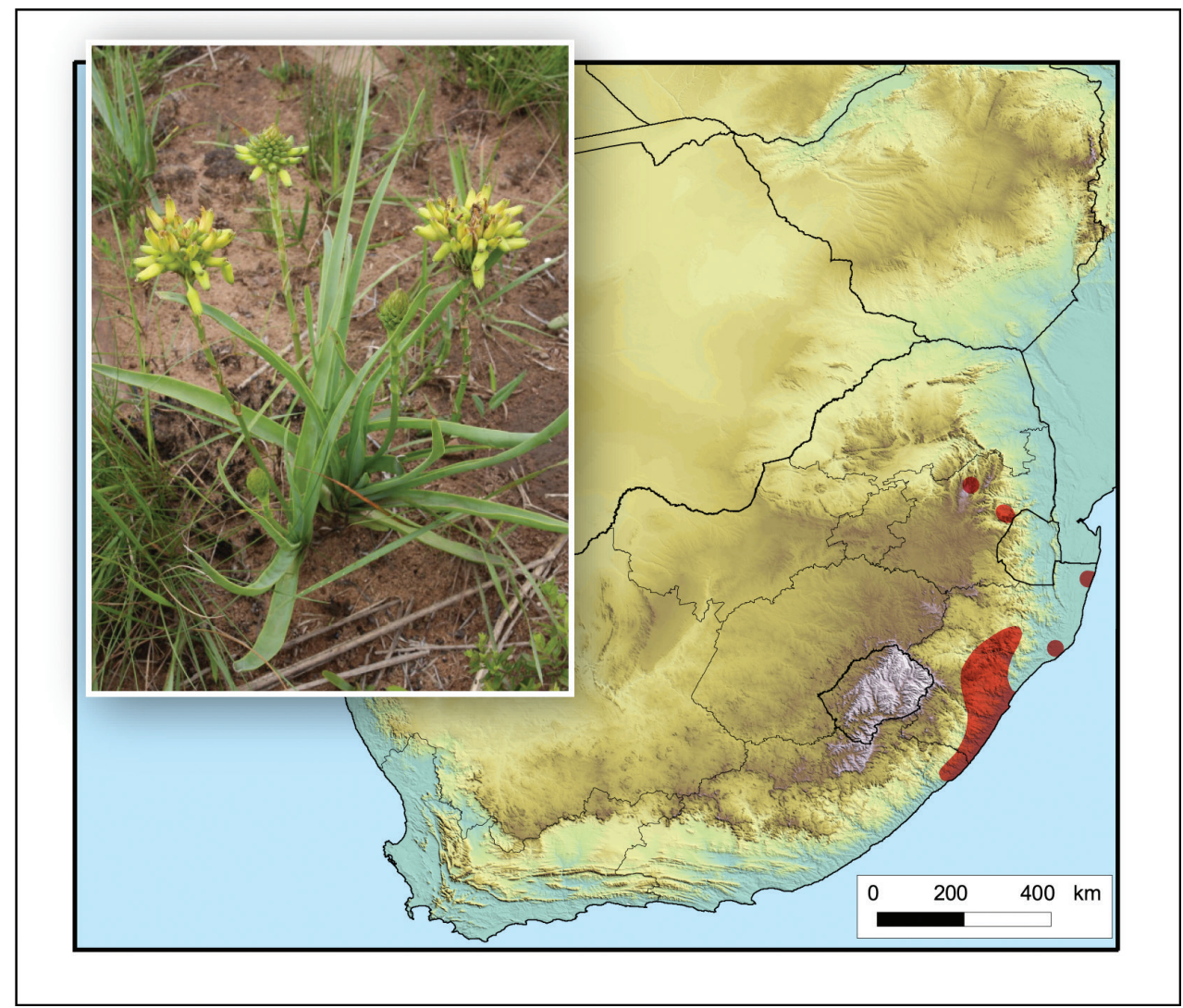

Figure 20. Aloe linearifolia. Photo: D. Styles.

and brown spots near the base on the lower surface. It is also characterised by the unbranched inflorescences $(0.20-0.35 \mathrm{~m}$ high) with dense, capitate racemes of short, yellow flowers ( $\pm 12 \mathrm{~mm}$ long) that are carried on stout pedicels (12-15 mm long). Rosettes are usually solitary or occasionally in small groups.

Conservation status. Least Concern. Threats include habitat transformation owing to commercial silvicultural and agricultural practices and urban expansion, as well as overgrazing and poor fire management (Raimondo et al. 2009, L. von Staden pers. comm.).

Distribution. Mainly found in the grasslands of southern and central KwaZuluNatal and the northern Eastern Cape, South Africa, with a few scattered collections from northern KwaZulu-Natal and Mpumalanga of South Africa; also just entering north-western Eswatini (Fig. 20).

\section{Aloe maculata All. subsp. maculata}

Common names. Common soap aloe (English); bontaalwyn (Afrikaans); amahlala, icena (isiZulu). 


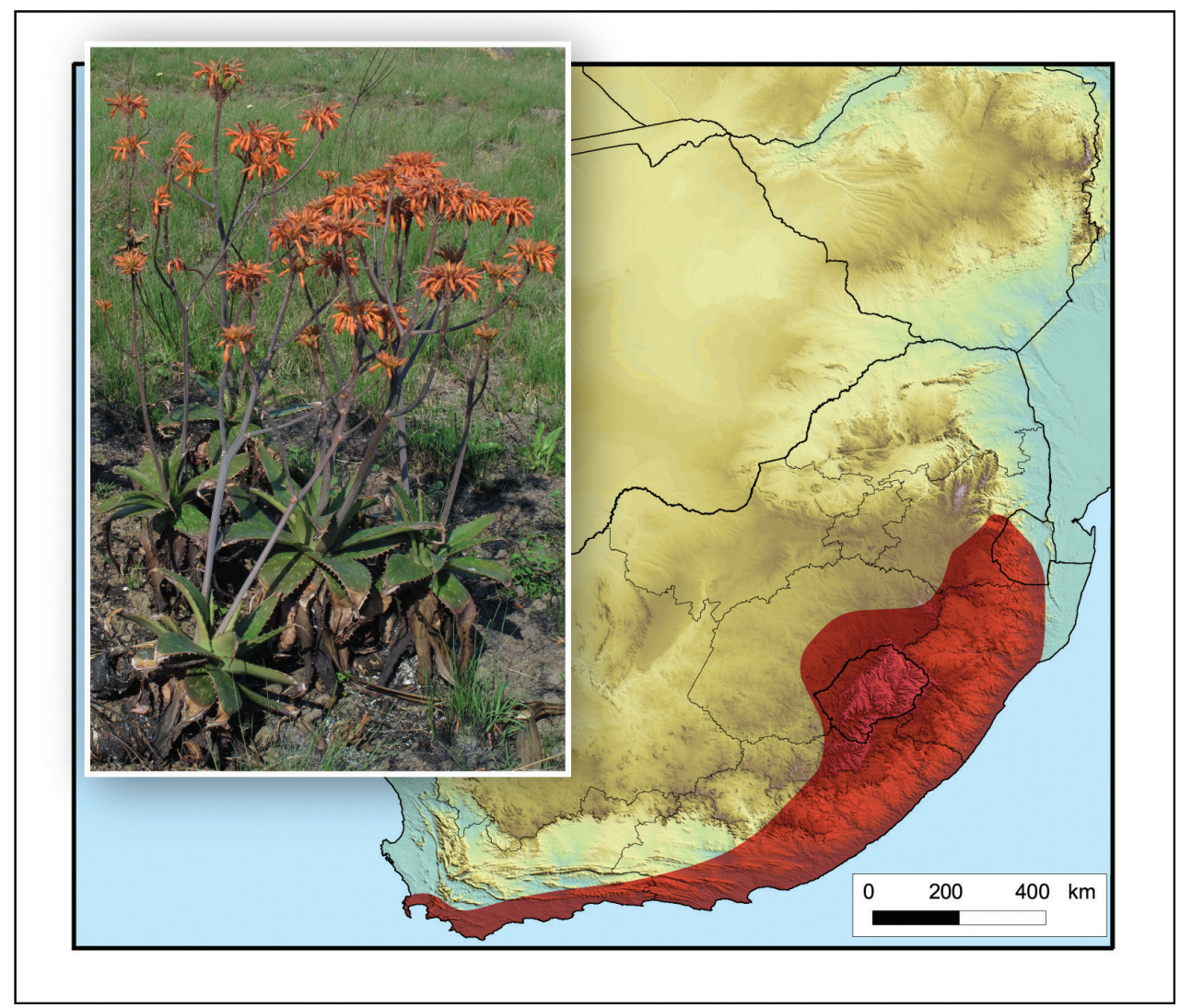

Figure 2I. Aloe maculata subsp. maculata. Photo: N.R. Crouch.

Description. Acaulescent plants or with stem up to $0.5 \mathrm{~m}$; rosettes solitary or suckering to form dense groups. Leaves densely rosulate, erectly spreading to slightly recurved, upper surface pale to darker green, with numerous, dull, white spots in irregular broken, wavy, transverse bands, lower surface paler green, obscurely lineate and usually without spots, ovate-lanceolate, up to $25-30 \mathrm{~cm}$ long, 8-12 cm wide, with dried twisted apex; margin with pungent, horny, brown teeth, 3-5 mm long, $\pm 10 \mathrm{~mm}$ apart; exudate clear. Inflorescence $0.4-1.0 \mathrm{~m}$ high, erect, branched. Racemes capitate-corymbose, $10-12 \mathrm{~cm}$ long, dense. Floral bracts \pm 12-23 mm long, 3-5 mm wide. Pedicels 35-45 mm long. Flowers: perianth usually salmon pink to orange, sometimes yellow or red, $35-50 \mathrm{~mm}$ long, up to $10 \mathrm{~mm}$ across ovary, abruptly constricted above ovary to form sub-globose basal swelling, enlarging towards wide open mouth, cylindrical, slightly decurved; outer segments free for 10-15 mm; stamens exserted 1-3 mm; style exserted to $5 \mathrm{~mm}$.

Flowering time. June-September in the north, December-January in the south.

Habitat. Variety of grasslands, scrub, thicket and on rocky outcrops.

Diagnostic characters. Aloe maculata subsp. maculata can be distinguished from other maculate aloes in KwaZulu-Natal (Aloe dewetii, Aloe mudenensis, Aloe parvibracteata, Aloe prinslooi, Aloe pruinosa, Aloe suffulta, Aloe umfoloziensis, Aloe vanrooyenii and 
Aloe viridiana) by its branched inflorescence (0.4-1.0 $\mathrm{m}$ high) with flat-topped, capitate, dense racemes (up to $10-12 \times 12-16 \mathrm{~cm}$ ) and pedicels of $35-45 \mathrm{~mm}$ long. Flowers are usually salmon pink to orange, sometimes yellow or red, $35-50 \mathrm{~mm}$ long, with a sub-globose basal swelling (up to $10 \mathrm{~mm}$ diameter). Leaves are spreading to slightly recurved, up to $25-30 \times 8-12 \mathrm{~cm}$ and spotted on the upper surface, with the paler lower surface obscurely lineate and usually without spots. Marginal teeth are 3-5 $\mathrm{mm}$ long.

Conservation status. Least Concern (Raimondo et al. 2009).

Distribution. This subspecies is one of the most widely distributed of the spotted aloes. It occurs from the Cape Peninsula through the Western and Eastern Cape, into the eastern Free State, through KwaZulu-Natal to Mpumalanga, South Africa; also in Lesotho and Eswatini (Fig. 21).

Notes. One other subspecies is recognised, namely A. maculata subsp. ficksburgensis (Reynolds) Gideon F.Sm. \& Figueiredo, which is only known from the eastern Free State, South Africa and western Lesotho.

\section{Aloe marlothii A.Berger}

Common names. Mountain aloe (English); bergaalwyn, boomaalwyn, snuifaalwyn (Afrikaans); ikhala, imihlaba, inhlaba, inhlabane, umhlaba (Zulu).

Stems simple, erect, up to $4 \mathrm{~m}$ high; leaves with many surface prickles; racemes 30-50 cm long; flowers 30-35 mm long

Aloe marlothii subsp. marlothii

- $\quad$ Stems suckering to form clumps, erect or oblique to procumbent, 1.00 $1.75 \mathrm{~m}$ high; leaves with no to few surface prickles; racemes $15-25 \mathrm{~cm}$ long; flowers $18-30 \mathrm{~mm}$ long.

Aloe marlothii subsp. orientalis Glen \& D.S.Hardy

Description. Solitary, arborescent plant of up to 5-6 m high (subsp. marlothii) or 1.00-1.75 m high (subsp. orientalis). Stem simple and erect (subsp. marlothii) or often suckering to form small groups and erect or oblique to procumbent (subsp. orientalis), densely covered with persistent dried leaves. Leaves densely rosulate, suberect to spreading and eventually pendent, dull grey-green to glaucous (subsp. marlothii) or arcuate-incurved to spreading or slightly decurved, glaucous to blue-green (subsp. orientalis), without spots, with scattered, reddish-brown, pungent spines, usually more copious on lower surface (subsp. marlothii) or with no to few surface prickles (subsp. orientalis), lanceolate-attenuate, $100-150 \mathrm{~cm}$ long, $20-25 \mathrm{~cm}$ wide at base (subsp. marlothii) or $75-150 \mathrm{~cm}$ long, $8-25 \mathrm{~cm}$ wide at base (subsp. orientalis); margin with stout, pungent, reddish-brown teeth, 3-6 mm long, 10-20 mm apart (subsp. marlothii) or 3-4 mm long, 8-25 mm apart (subsp. orientalis); exudate honey-coloured. Inflorescence up to $0.8 \mathrm{~m}$ high, 10 - to 30 -branched from below middle, lower branch- 
es rebranched, branches horizontal to spreading. Racemes cylindrical, $30-50 \mathrm{~cm}$ long, horizontal to suboblique (subsp. marlothii) or 15-25 cm long, spreading to rarely erect (subsp. orientalis), dense; flowers markedly secund when open. Floral bracts $8-9 \mathrm{~mm}$ long, $5 \mathrm{~mm}$ wide (subsp. marlothii) or 4-9 $\mathrm{mm}$ long, 2-5 mm wide (subsp. orientalis). Pedicels 5-8 mm (subsp. marlothii) or 3-5 mm (subsp. orientalis) long. Flowers: perianth orange to yellowish-orange, $30-35 \mathrm{~mm}$ long, $\pm 7 \mathrm{~mm}$ wide across ovary (subsp. marlothii) or yellow to orange, $18-30 \mathrm{~mm}$ long (subsp. orientalis), enlarging above ovary, narrowing towards usually wide-open mouth, cylindrical-clavate to cylindrical-ventricose (subsp. marlothii) or cylindrical to ventricose (subsp. orientalis); outer segments free for $20-23 \mathrm{~mm}$ (subsp. marlothii) or for 6-15 mm (subsp. orientalis); stamens exserted to $15 \mathrm{~mm}$; style exserted 15-20 mm (subsp. marlothii) or stamens and style exserted 8-12 mm (subsp. orientalis).

Flowering time. June-August, as late as September along the Witwatersrand, Gauteng, South Africa (subsp. marlothii). July-August (subsp. orientalis).

Habitat. Aloe marlothii subsp. marlothii grows in a wide variety of habitats, including bushveld on stony, usually bare soils or rocky outcrops. Aloe marlothii subsp. orientalis is confined to coastal grassland in sandy soil.

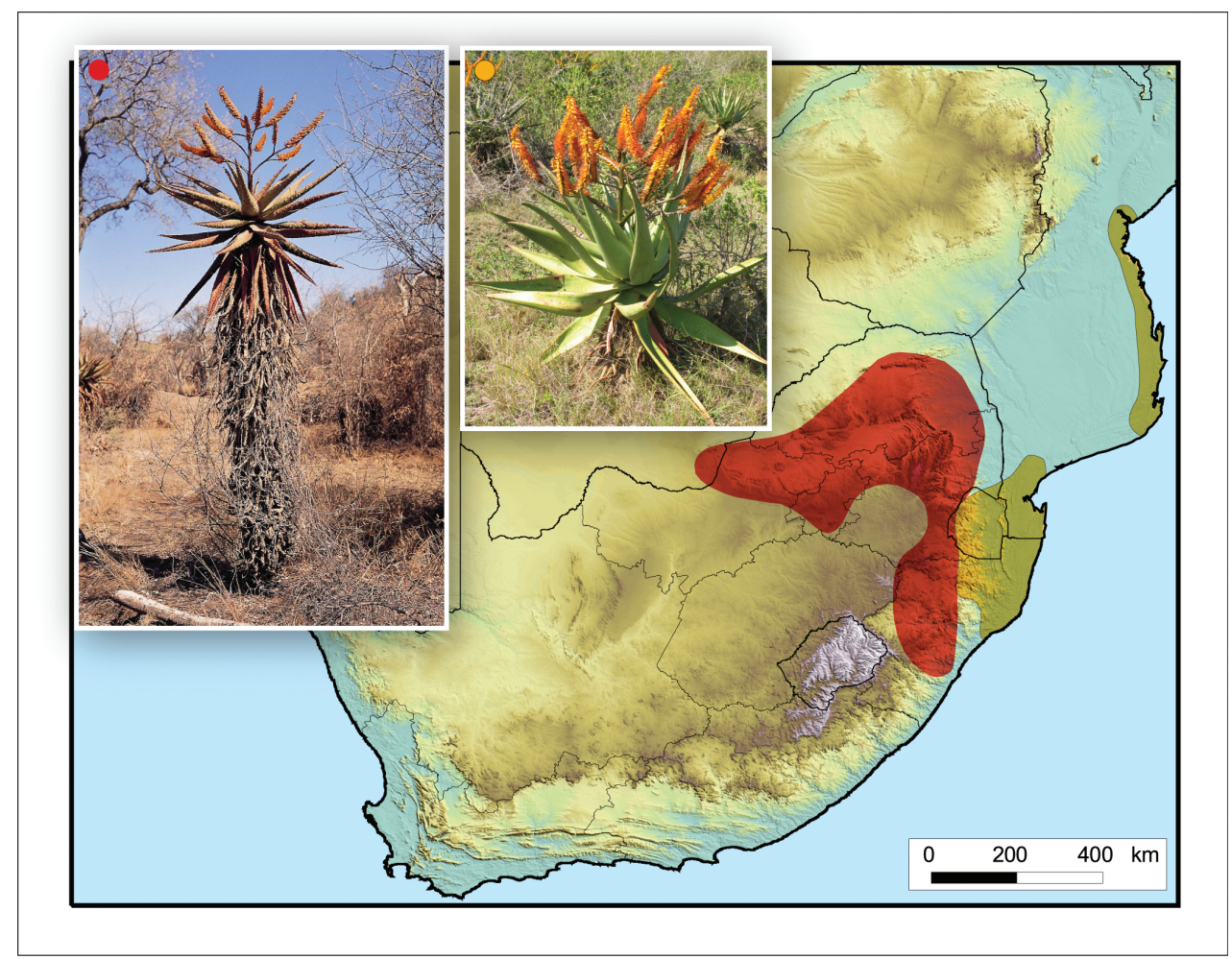

Figure 22. Aloe marlothii subsp. marlothii (red on map) and Aloe marlothii subsp. orientalis (orange on map). Photos: G.F. Smith (subsp. marlothii), N.R. Crouch (subsp. orientalis). 
Diagnostic characters. Aloe marlothii differs from the other tall often single-stemmed aloes in KwaZulu-Natal with branched inflorescences and persistent dried leaves (Aloe candelabrum, Aloe pluridens, Aloe rupestris, Aloe spectabilis and Aloe thraskii), by having its racemes horizontal to oblique (not erect) with the flowers secund. The inflorescence is much-branched with up to 30 racemes. Flowers are yellow to orange, up to $35 \mathrm{~mm}$ long with the inner segment tips purplish and the exserted portion of stamens deep purple (not deep purplish-black to black segment tips and orange filaments as in Aloe spectabilis). Aloe marlothii subsp. marlothii is further distinguished by the presence of copious spines on both leaf surfaces. The main characters separating Aloe marlothii subsp. orientalis Glen $\&$ D.S.Hardy from the typical subspecies is its short stems of up to $1.75 \mathrm{~m}$ (not up to $4 \mathrm{~m}$ ), that are sometimes oblique or procumbent and often suckering to form clumps (not solitary rosettes). Its leaves also have no or only a few surface prickles, while its racemes are usually oblique (not as horizontal as in subsp. marlothii). Drying leaves of Aloe marlothii subsp. orientalis have a peculiar, unpleasant odour (Glen and Hardy 1987).

Conservation status. Both subspecies are Least Concern (Raimondo et al. 2009).

Distribution. Aloe marlothii subsp. marlothii (red on map) is widespread throughout North-West, Limpopo (as far north as the Soutpansberg), Mpumalanga, Gauteng and KwaZulu-Natal in South Africa, as well as in south-eastern Botswana and into western Eswatini. Aloe marlothii subsp. orientalis (orange on map) is only known from northern KwaZulu-Natal in South Africa, as well as southern Mozambique and low lying areas of Eswatini (Fig. 22). It is near-endemic to the Maputaland Centre of Endemism.

Notes. Aloe marlothii grades through intermediates into Aloe spectabilis Reynolds at some localities (Reynolds 1950). As a result, the two species are considered conspecific by some authors (Glen and Hardy 2000; Carter et al. 2011).

\section{Aloe micracantha Haw.}

Common names. Wateraalwyn (Afrikaans).

Description. Grass aloe, $0.35-0.50 \mathrm{~m}$ high; rosettes usually solitary. Acaulescent plants or stem very short, simple, sometimes 1- or 2-branched, erect. Leaves multifarious, sub-distichous in young plants, erect, rigid, deep green to yellowish-green, with copious white, subtuberculate and subspinulescent spots especially on lower surface towards base, deeply channelled on upper surface, narrowly deltoid to linear, acuminate, $30-50 \mathrm{~cm}$ long, 2-4 cm wide at base; margin with firm, white teeth, up to $2 \mathrm{~mm}$ long, 1-3 mm apart; exudate clear. Inflorescence $0.45-0.50 \mathrm{~m}$ high, erect, simple. Raceme capitate, somewhat corymbose, $\pm 8 \mathrm{~cm}$ long, dense. Floral bracts $\pm 35 \mathrm{~mm}$ long, 5-7 mm wide. Pedicels 20-35 mm long. Flowers: perianth salmon-pink to reddishorange, 25-40 mm long, slightly constricted above ovary, slightly widening towards wide open mouth, basally stipitate, straight, cylindrical-trigonous; outer segments free to base; stamens exserted 0-1 $\mathrm{mm}$; style exserted 1-2 $\mathrm{mm}$.

Flowering time. January-March.

Habitat. Well-drained, dry, open sandy or stony places in coastal grassland, often wedged between rocks. 


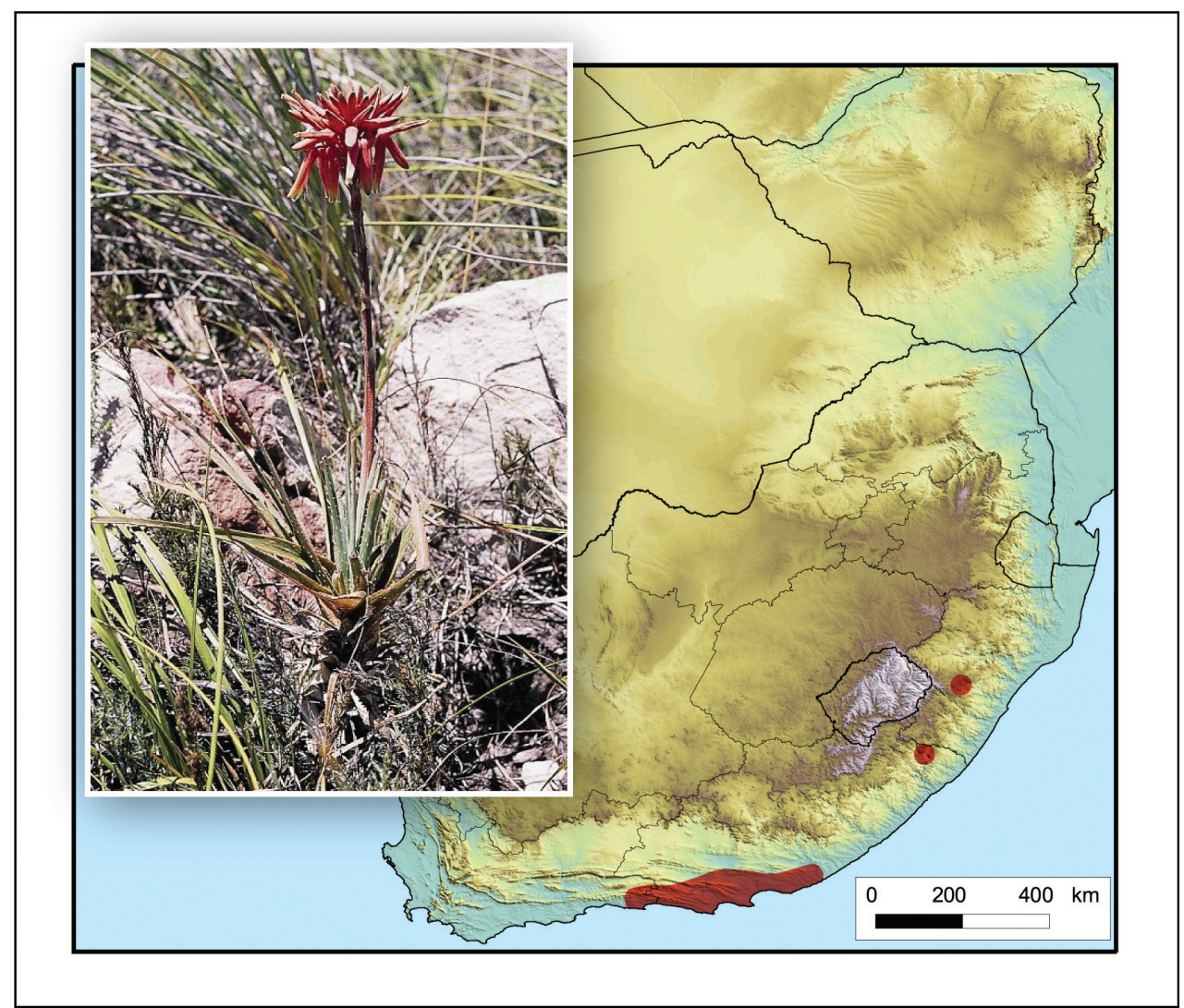

Figure 23. Aloe micracantha. Photo: G.F. Smith.

Diagnostic characters. Aloe micracantha can be distinguished from other grass aloes in KwaZulu-Natal with unkeeled leaves that are usually narrower than $3.5 \mathrm{~cm}$ and that lack a bulb-like underground swelling (Aloe dominella, Aloe linearifolia, Aloe minima, Aloe nicholsii, Aloe parviflora and Aloe saundersiae), by the multifarious to subdistichous, erect and rigid, deep yellowish-green, smoothly channelled (not sharply keeled) leaves $(30-50 \times 2-4 \mathrm{~cm})$, with copious white spots on both surfaces. It is also characterised by the unbranched inflorescences $(0.45-0.50 \mathrm{~m}$ high) with dense, capitate racemes, where the pedicels (20-35 mm long), perianth (25-40 mm long) and ovary are all salmon-pink. Rosettes are usually solitary.

Conservation status. Near-threatened. Threats include agricultural practices, urban expansion and the encroachment of alien invasives (Raimondo et al. 2009).

Distribution. Occurs in a fairly narrow coastal to near-coastal strip from the Uniondale area in the Western Cape to Bathurst in the Eastern Cape, with outlier collections from Mt Ayliff in the north-eastern Eastern Cape and Karkloof in KwaZuluNatal, South Africa (Fig. 23). It is the grass aloe with the most westerly distribution in southern Africa and the only grass aloe to occur in Fynbos vegetation. 


\section{Aloe minima Baker}

Common names. Pink grass aloe (English); isipukushane, isipukutwane, isiputuma, isiphuthumane, isiphukhutshane (Zulu).

Description. Grass aloe, 0.2-0.3 m high. Acaulescent plants; rosettes single, erect. Leaves rosulate, suberect, rather rigid, green, lower surface with copious slightly tuberculate-spinulescent spots towards base, linear, 25-35 cm long, 0.4-0.6 cm wide; margin ciliate, with minute whitish teeth in lower half, up to $0.5 \mathrm{~mm}$ long, $1-2 \mathrm{~mm}$ apart; exudate clear. Inflorescence $0.25-0.50 \mathrm{~m}$ high, erect, simple. Raceme capitate, $\pm 3 \mathrm{~cm}$ long, dense. Floral bracts 5-12 $\mathrm{mm}$ long, 3-5 mm wide. Pedicels $10-20 \mathrm{~mm}$ long. Flowers: perianth dull pink, $10-11 \mathrm{~mm}$ long, $\pm 3-4 \mathrm{~mm}$ across ovary, narrowing towards upturned mouth, basally stipitate, cylindric-trigonous; outer segments free to base; stamens and stigma not or only slightly exserted.

Flowering time. January-February.

Habitat. Hilly and mountainous grassland on fairly heavy soils with loose stones.

Diagnostic characters. Aloe minima can be distinguished from other grass aloes in KwaZulu-Natal with unkeeled leaves that are usually narrower than $3.5 \mathrm{~cm}$ and that lack a bulb-like underground swelling (Aloe dominella, Aloe linearifolia, Aloe micra-

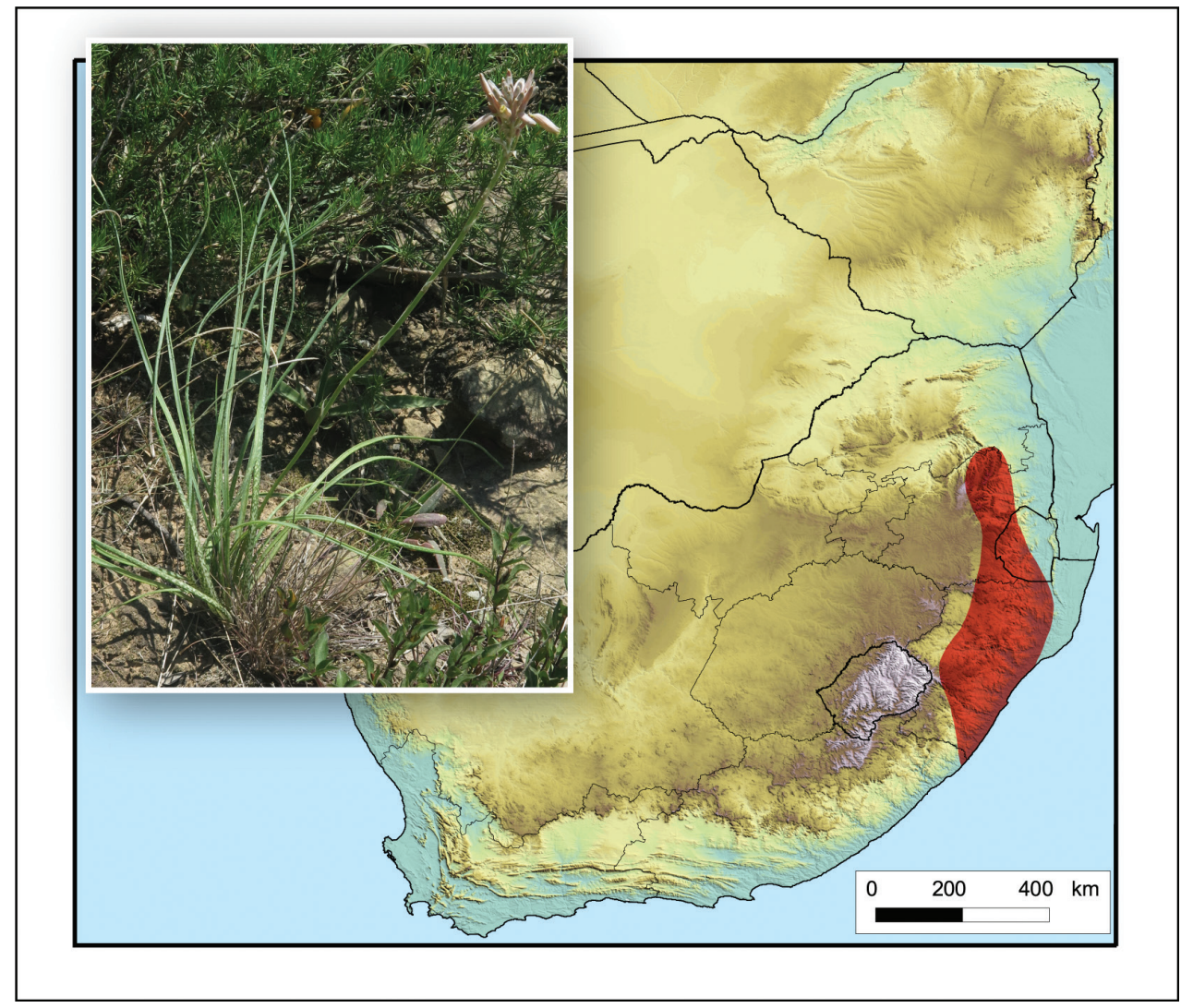

Figure 24. Aloe minima. Photo: N.R. Crouch. 
cantha, Aloe nicholsii, Aloe parviflora and Aloe saundersiae), by the short inflorescence $(0.25-0.50 \mathrm{~m}$ high) with dense, capitate racemes and pedicels $10-20 \mathrm{~mm}$ long. The peduncle is smooth (without prickles as in Aloe parviflora). Flowers are small (10$11 \mathrm{~mm}$ long) and dull pink, with a spreading, upturned mouth. The rosulate leaves $(25-35 \times 0.4-0.6 \mathrm{~cm})$ are suberect and rather rigid, with copious slightly tuberculatespinulescent spots towards the base on the lower surface. Rosettes are solitary.

Conservation status. Least Concern (Raimondo et al. 2009).

Distribution. Occurs from the far northern parts of the Eastern Cape, just south of Port Edward, widespread through KwaZulu-Natal and along the Great Escarpment into Mpumalanga, South Africa and western Eswatini (Fig. 24).

\section{Aloe modesta Reynolds}

Common names. Vlei aloe (English); vlei-aalwyn (Afrikaans).

Description. Grass aloe. Acaulescent plants; rosettes solitary, erect, $0.2-0.3 \mathrm{~m}$ high; leaf bases forming bulb-like swelling underground. Leaves rosulate, erect, dull deep green, upper surface without spots, lower surface copiously white-spotted near base, linear-acute, slightly channelled on upper surface, $15-20 \mathrm{~cm}$ long, $0.8-0.9 \mathrm{~cm}$ wide at ground level; margin exceedingly narrow, cartilaginous, translucent, without teeth or with minute soft whitish teeth; exudate clear. Inflorescence $0.25-0.30 \mathrm{~m}$ high, erect, simple. Raceme subcapitate, slightly conical, $3.5-4.0 \mathrm{~cm}$ long, 3.0 $3.5 \mathrm{~cm}$ wide, very dense. Floral bracts $10-13 \mathrm{~mm}$ long, $4-6 \mathrm{~mm}$ wide. Pedicels $1 \mathrm{~mm}$ long. Flowers: perianth yellowish-green, scented, 10-15 mm long, $4 \mathrm{~mm}$ across ovary, not narrowed above ovary, slightly narrowed towards slightly upturned mouth, cylindrical-trigonous; outer segments free to base; stamens exserted 2-3 mm; style exserted 3-5 $\mathrm{mm}$.

Flowering time. January-February.

Habitat. Stony ground in high altitude open grassland in areas characterised by cold winters and high rainfall. Reasonably heavy and sometimes shale soils.

Diagnostic characters. Aloe modesta can be distinguished from other grass aloes in KwaZulu-Natal where the leaf bases form a subterranean bulb-like swelling (Aloe bergeriana, Aloe inconspicua and Aloe kniphofioides), by the narrow leaves (15-20 × 0.8$0.9 \mathrm{~cm}$ ) with minute translucent marginal teeth and that are copiously spotted near the base of the lower surface. It is also characterised by the very dense, unbranched, subcapitate raceme $(3.5-4.0 \mathrm{~cm}$ long) with almost sessile, yellow, sweetly scented flowers (10-15 mm long). It is the only species of aloe with scented flowers outside of Madagascar (Dyer and Hardy 1974; Van der Riet 1977; Glen and Hardy 2000).

Conservation status. Endangered. Threats include commercial afforestation, overgrazing, alien invasives and urban expansion (Raimondo et al. 2009, L. von Staden pers. comm.).

Distribution. Known only from the mountains around Barberton and near Dullstroom and Lydenburg, Mpumalanga and from the Wakkerstroom area near the KwaZulu-Natal border, South Africa (Fig. 25). 


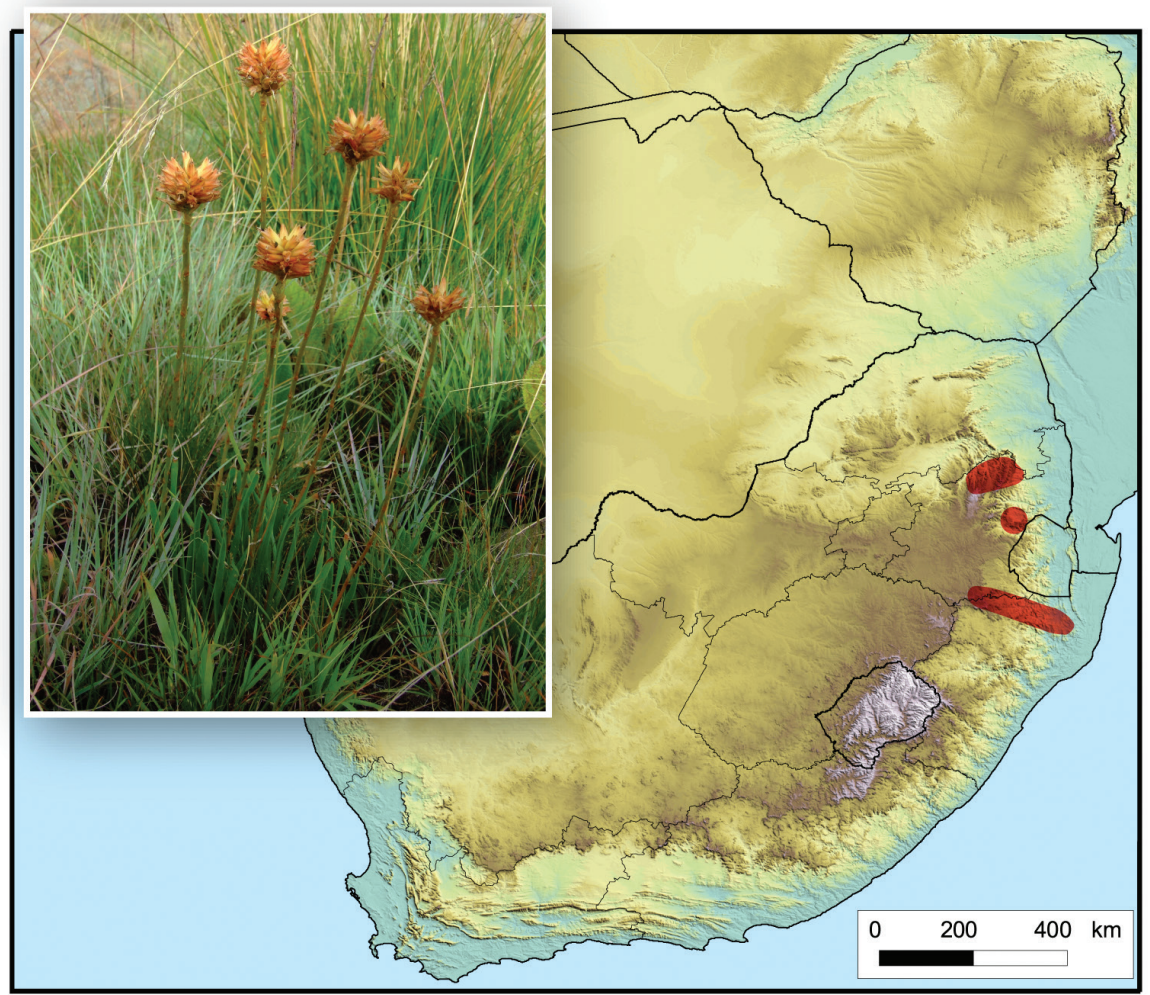

Figure 25. Aloe modesta. Photo: H.M. Steyn.

\section{${ }^{\mathrm{NE}}$ Aloe mudenensis Reynolds}

Common names. Muden aloe (English); kleinaalwyn (Afrikaans); icena (Zulu).

Description. Caulescent plants, $0.25-0.5 \mathrm{~m}$ tall; rosettes simple or sometimes in small groups. Stem sometimes absent, usually up to $0.8 \mathrm{~m}$, unbranched, erect or sometimes decumbent, without persistent dried leaves. Leaves densely rosulate, spreading, bluish-green, paler on lower surface, with numerous irregularly scattered white oblong spots on both surfaces, spots sometimes in irregular transverse bands, sometimes lineate, lower surface sometimes without spots and lineate, ovate-lanceolate, attenuate, $25-30 \mathrm{~cm}$ long, 8-9 cm wide; margin horny, with pungent, deltoid, brown, usually straight teeth, up to $7 \mathrm{~mm}$ long, 10-20 $\mathrm{mm}$ apart; exudate clear, drying reddish-purple. Inflorescence up to $1 \mathrm{~m}$ high, erect, 4- to 8-branched from about middle or below. Racemes subcapitate, broadly cylindrical, slightly conical, $\pm 12 \mathrm{~cm}$ long, $8-9 \mathrm{~cm}$ wide, rather dense. Floral bracts $12-15 \mathrm{~cm}, 2-4 \mathrm{~mm}$ wide. Pedicels $20-25 \mathrm{~cm}$ long. Flowers: perianth salmonorange, sometimes red, 25-35 mm long, $8 \mathrm{~mm}$ across ovary, abruptly constricted above ovary to form subglobose basal swelling, enlarging towards wide-open mouth, slightly decurved; outer segments free for 5-9 $\mathrm{mm}$; stamens exserted to $4 \mathrm{~mm}$; style exserted to $5 \mathrm{~mm}$. 


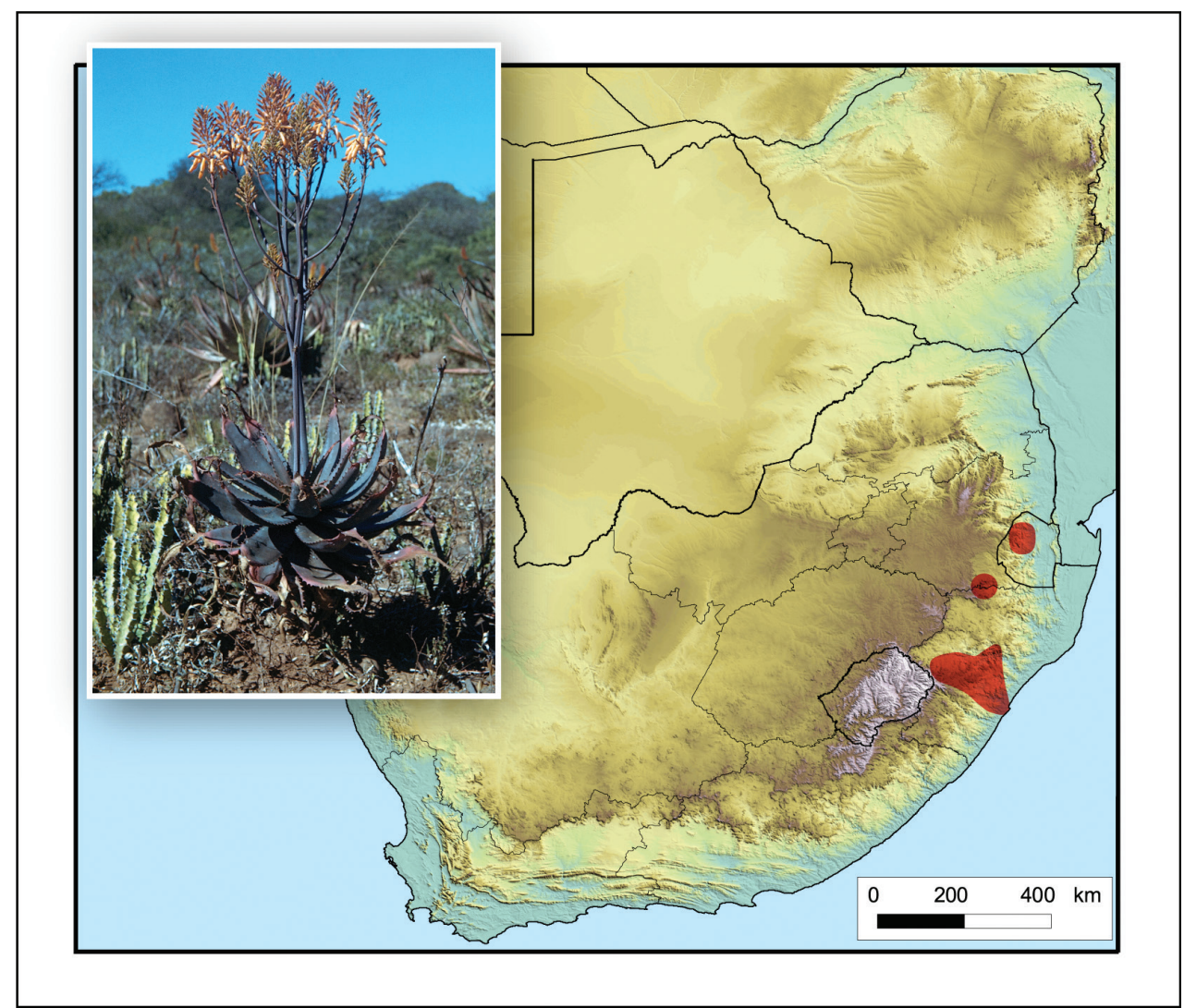

Figure 26. Aloe mudenensis. Photo: G.W. Reynolds.

Flowering time. June-July.

Habitat. Valley bushveld and thicket on sandy loam. Lower areas of warm valleys.

Diagnostic characters. Aloe mudenensis can be distinguished from other maculate aloes in KwaZulu-Natal (Aloe dewetii, Aloe maculata subsp. maculata, Aloe parvibracteata, Aloe prinslooi, Aloe pruinosa, Aloe suffulta, Aloe umfoloziensis, Aloe vanrooyenii and Aloe viridiana) by the short, usually erect stem, without persistent dried leaves. Rosettes are usually solitary or in small groups. Leaves are spreading, 25-30 × $8-9 \mathrm{~cm}$ and spotted on both surfaces, with the paler lower surface sometimes without spots and lineate. Marginal teeth are up to $7 \mathrm{~mm}$ long. The 4- to 8-branched inflorescence (up to $1 \mathrm{~m}$ high) has rather dense, cylindrical, yet terminally rounded racemes $( \pm 12 \times 8-9 \mathrm{~cm})$ with spreading buds and flowers. Pedicels are $20-25 \mathrm{~cm}$ long. Flowers are salmon-orange, sometimes red, $25-35 \mathrm{~mm}$ long and with a subglobose basal swelling (8 $\mathrm{mm}$ diameter).

Conservation status. Near-threatened. Threats include silviculture, agriculture (mainly sugarcane) and urban expansion, as well as overgrazing (L. von Staden pers. comm.).

Distribution. KwaZulu-Natal midlands, on the Mpumalanga border with northern KwaZulu-Natal, South Africa and in Eswatini (Fig. 26). 


\section{Aloe myriacantha (Haw.) Schult. \& Schult.f.}

Common names. umakhuphulwane (Zulu).

Description. Grass aloe, $0.2-0.3 \mathrm{~m}$ high. Acaulescent plants; rosettes solitary or sometimes suckering to form small groups. Leaves rosulate, erectly spreading, dull green, with few white spots towards base, with more copious somewhat tuberculatesubspinulescent spots on lower surface, narrowly linear, keeled, $\pm 25 \mathrm{~cm}$ long, $0.4-$ $1.0 \mathrm{~cm}$ wide; margin with minute white teeth, up to $0.5-1 \mathrm{~mm}$ long and more crowded near base, smaller towards apex; exudate clear. Inflorescence $0.20-0.30 \mathrm{~m}$ high, erect, simple. Raceme capitate, $4.5-8.0 \mathrm{~cm}$ long, dense. Floral bracts $10-20 \mathrm{~mm}$ long, 5-12 mm wide. Pedicels $10-25 \mathrm{~mm}$ long. Flowers: perianth dull white to dull reddish-pink or purple, rarely greenish-white, $15-20 \mathrm{~mm}$ long, not or only slightly narrowed above ovary, basally substipitate, narrowing slightly towards mouth, cylindrical-trigonous, mouth distinctly bilabiate and upturned; outer segments free to base; stamens and style exserted $0-1 \mathrm{~mm}$.

Flowering time. January-May/April (southern Africa), May-June (Kenya and Uganda).

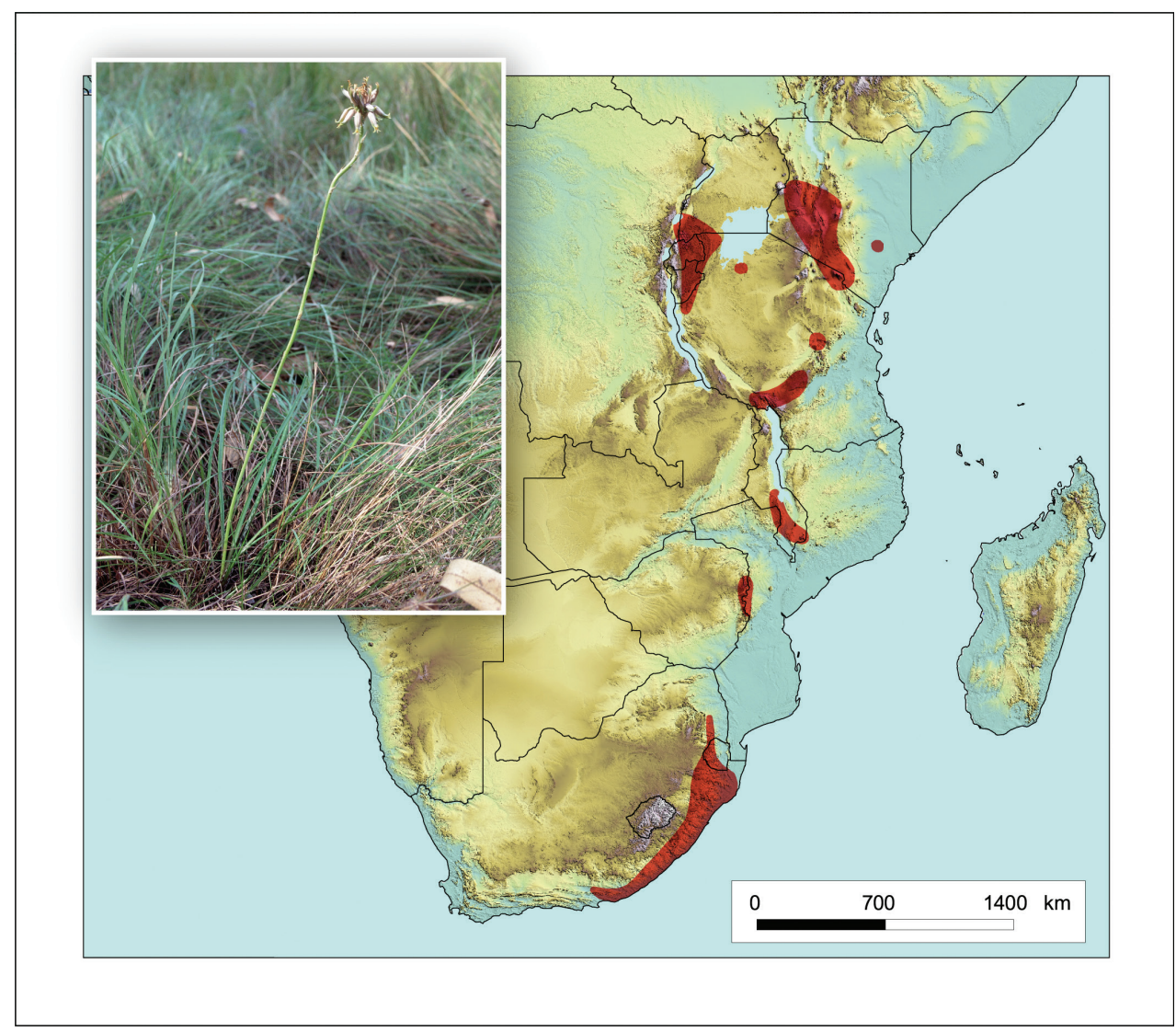

Figure 27. Aloe myriacantha. Photo: N.R. Crouch. 
Habitat. Grows amongst rocks and on rocky slopes in high-altitude montane grassland.

Diagnostic characters. Aloe myriacantha is distinguished from other grass aloes in KwaZulu-Natal with strongly-keeled leaves (Aloe cooperi and Aloe sharoniae) by the dull pinkish-red flowers (15-20 mm long) with a distinctly bilabiate upturned mouth. The inflorescence $(0.20-0.30 \mathrm{~m}$ high) is equal to or slightly longer than the rosulate leaves $( \pm 25 \mathrm{~cm}$ long). Leaves have a minutely toothed margin and have spots near the base, with the spots more copious and somewhat tuberculate-subspinulescent on the lower surface.

Conservation status. Least Concern (Raimondo et al. 2009).

Distribution. A typical Afromontane (sensu White 1983) floristic element, this species has probably the widest distribution range of any Aloe. It occurs from the Humansdorp area in the Eastern Cape, along the coast and widespread through KwaZulu-Natal, northwards along the escarpment to the Bosbokrand area in Mpumalanga, South Africa and also in western Eswatini. It is also found further north on the border between Zimbabwe and Mozambique, in Malawi and the Eastern Arc of mountains in Tanzania and Kenya, as well as Uganda, Burundi and Rwanda in southern Tropical Africa (Fig. 27).

\section{${ }^{\mathrm{E}}$ Aloe neilcrouchii Klopper \& Gideon F.Sm.}

Common names. Neil's aloe (English); neilse-aalwyn (Afrikaans).

Description. Grass aloe. Stem up to $0.95 \mathrm{~m}$ long, decumbent to erect, branched mainly from base, forming robust offshoots along its length, without persistent dried leaves. Leaves deciduous, densely rosulate, erectly spreading, green, with numerous elongated, white, somewhat tuberculate spots on both surfaces, deltoid to ovate-lanceolate, up to $43 \mathrm{~cm}$ long, up to $13.5 \mathrm{~cm}$ wide at base; margin narrow, cartilaginous, whitish, with small whitish, deltoid, irregularly spaced teeth, 1-2 mm long, 2-5 mm apart; leaf exudate clear, drying clear, not bitter. Inflorescence 0.6-0.8 m high, erect, simple. Raceme capitate, $\pm 12 \mathrm{~cm}$ long, $10 \mathrm{~cm}$ wide, dense. Floral bracts $\pm 30 \mathrm{~mm}$ long, 7 mm wide. Pedicels 30-45 mm long. Flowers: perianth salmon-pink, greentipped, $\pm 45 \mathrm{~mm}$ long, 10-13 mm across ovary, slightly narrowed above ovary, slightly constricted just before flared mouth, cylindrical-trigonous; outer segments free almost to base; stamens not or only slightly exserted; style exserted to $\pm 5 \mathrm{~mm}$.

Flowering time. December-January.

Habitat. Southeast-facing aspects in rocky grassland.

Diagnostic characters. Aloe neilcrouchii can be distinguished from other grass aloes in KwaZulu-Natal with unkeeled leaves that are wider than $3.5 \mathrm{~cm}$ (Aloe boylei, Aloe ecklonis, Aloe hlangapies and Aloe kraussii), by the large rosettes of erectly spreading, rosulate leaves (up to $43 \times 13.5 \mathrm{~cm}$ ), with copious white tuberculate spots on both surfaces. It is further characterised by the long, sprawling, leafless stems of up to almost $1 \mathrm{~m}$ long, which branch at the base and form offshoots along its length. The unbranched inflorescences (0.6-0.8 $\mathrm{m}$ high) have dense, capitate racemes $( \pm 12 \mathrm{~cm}$ long) 


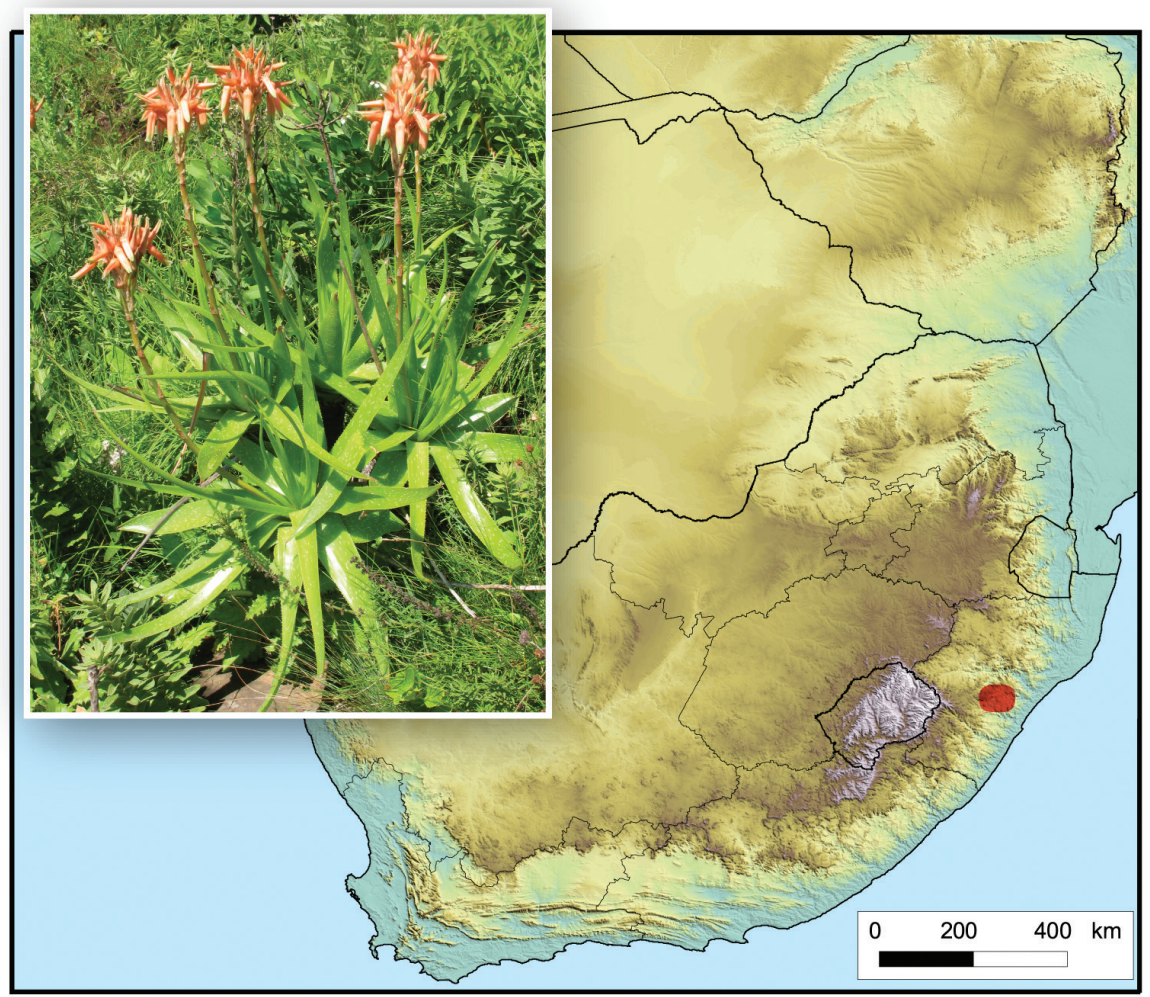

Figure 28. Aloe neilcrouchii. Photo: N.R. Crouch.

with large ( $\pm 45 \mathrm{~mm}$ long), salmon-pink, rather straight flowers. This is the largest and most robust species of the leptoaloe group, also known as 'slender aloes' (Klopper and Smith 2010; Smith et al. 2011).

Conservation status. Endangered. Threats include habitat fragmentation and destruction owing to commercial silvicultural and agricultural practices (Johnson et al. 2011).

Distribution. Known from only two localities near Karkloof and New Hanover, in the midlands of KwaZulu-Natal, South Africa (Fig. 28).

\section{${ }^{\mathrm{E}}$ Aloe nicholsii Gideon F.Sm. \& N.R.Crouch}

Common names. Shiny aloe (English); blinkaalwyn (Afrikaans).

Description. Grass aloe of $\pm 0.30-0.36 \mathrm{~m}$ tall. Stem short, $\pm 0.06-0.14 \mathrm{~m}$ high, erect, sometimes unbranched, usually suckering to form clumps; without persistent dried leaves. Leaves distichous becoming semi-rosulate, flaccidly spreading, mid-green to light yellowish-green, occasionally with a few scattered white spots towards base, spots more common on lower surface, texture smooth, narrowly linear, tapering to- 


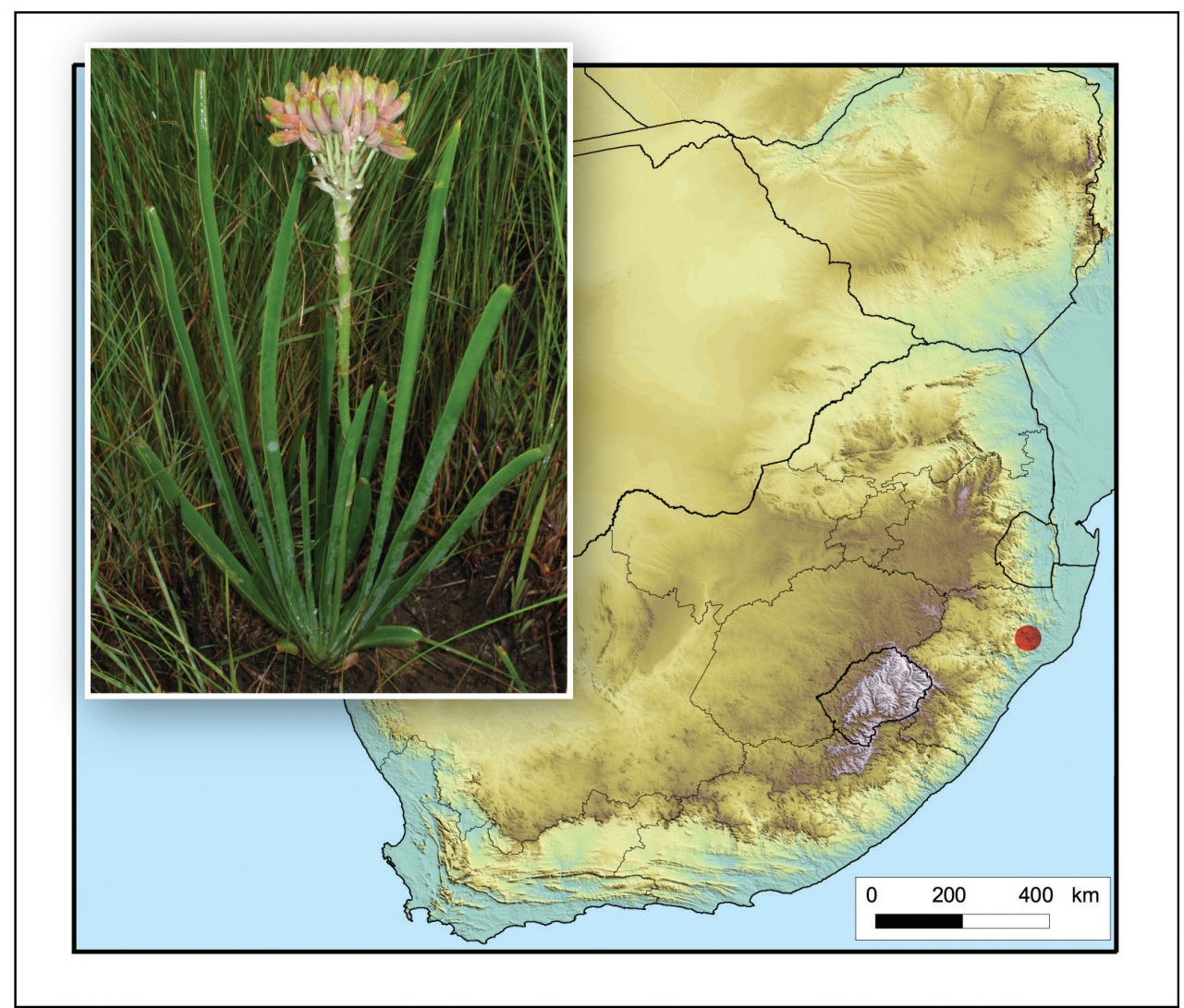

Figure 29. Aloe nicholsii. Photo: N.R. Crouch.

wards apex, canaliculate, $20-46 \mathrm{~cm}$ long, $2.0-3.5 \mathrm{~cm}$ wide; margin coarse, faintly ivory-coloured, mostly without teeth or sometimes with tiny, harmless, triangular, ivory-coloured to greenish-white teeth, less than $0.5 \mathrm{~mm}$ long, 5-10 mm apart; exudate drying translucent. Inflorescence $0.30-0.46 \mathrm{~m}$ tall, erect, simple. Raceme capitate, $3.0-3.5 \mathrm{~cm}$ long, 5-6 cm wide, dense. Floral bracts 10-26 mm long. Pedicels 25-30 mm long. Flowers: perianth metallic salmon-pink above, greenish below, purplish-brown tipped, lightly pruinose, $13-16 \mathrm{~mm}$ long, $5 \mathrm{~mm}$ across middle, enlarging towards slightly open, distinctly upturned mouth, tubular cymbiform; outer segments free for most of their length; stamens not exserted; style exserted.

Flowering time. January-March.

Habitat. Open rocky grassland.

Diagnostic characters. Aloe nicholsii can be distinguished from other grass aloes in KwaZulu-Natal with unkeeled leaves that are usually narrower than $3.5 \mathrm{~cm}$ and that lack a bulb-like underground swelling (Aloe dominella, Aloe linearifolia, Aloe micracantha, Aloe minima, Aloe parviflora and Aloe saundersiae), by the unbranched inflorescences (0.30-0.46 m high) with dense, capitate racemes and pedicels $25-30 \mathrm{~mm}$ long. The small flowers (13-16 mm long) are pruinose, greenish below and a metallic 
salmon-pink above, with a distinctly upturned mouth. The distichous to semi-rosulate leaves $(20-46 \times 2.0-3.5 \mathrm{~cm})$ are flaccidly spreading and occasionally with a few scattered white spots towards the base, more commonly on the lower surface. Rosettes are usually in dense groups (Crouch et al. 2011).

Conservation status. Critically Endangered. Threats include habitat degradation due to overgrazing, urban expansion and commercial afforestation (Von Staden 2013).

Distribution. Known from a small area near Babanango in the KwaZulu-Natal midlands, South Africa (Fig. 29).

\section{Aloe parvibracteata Schönland nom. cons.}

Common names. Lowveld spotted aloe (English); pers-bontaalwyn (Afrikaans); icena, inkalane (Zulu).

Description. Acaulescent plants or stem very short, up to $0.4 \mathrm{~m}$ tall; rosettes suckering to form large dense groups. Leaves densely rosulate, spreading-decurved, upper surface green to brownish-green to purplish-green, with numerous oblong dull white spots, usually arranged in interrupted, undulating transverse bands, lower surface paler green, usually without spots, narrowly lanceolate, gradually attenuate, $30-40 \mathrm{~cm}$ long, 6-10 cm wide at base; margin with pungent brown teeth, sometimes remarkably deflexed, 3-5 mm long, 10-15 mm apart; exudate honey-coloured, drying deep purple. Inflorescences 1.0-1.5 m high, erect, 4- to 8-branched from above middle. Racemes cylindrical, slightly acuminate, terminal $15-30 \mathrm{~cm}$ long, 6-7 cm wide, lateral shorter, lax. Floral bracts $8-12 \mathrm{~mm}$ long. Pedicels $6-15 \mathrm{~mm}$ long. Flowers: perianth dull to somewhat glossy red or orange, $30-40 \mathrm{~mm}$ long, $7-9 \mathrm{~mm}$ across ovary, abruptly constricted above ovary to form globose basal swelling, enlarging towards sometimes wide-open mouth, slightly decurved; outer segments free for $8-10 \mathrm{~mm}$; stamens and style exserted 1-2 mm.

Flowering time. June-July.

Habitat. On rocky outcrops in flat grassland in hot, low-lying thorny savannah and similar thorny woodland in the Lebombo Mountains.

Diagnostic characters. Aloe parvibracteata can be distinguished from other maculate aloes in KwaZulu-Natal (Aloe dewetii, Aloe maculata subsp. maculata, Aloe mudenensis, Aloe prinslooi, Aloe pruinosa, Aloe suffulta, Aloe umfoloziensis, Aloe vanrooyenii and Aloe viridiana) by the rosettes that sucker profusely to form large groups. It is further characterised by the spreading-decurved almost depressed leaves $(30-40 \times 6-10 \mathrm{~cm})$ that give the rosette a 'flattened out' appearance. Leaves are spotted on the upper surface, while the paler lower surface is usually without spots and marginal teeth are 3-5 $\mathrm{mm}$ long. The 4- to 8-branched inflorescence (1.0-1.5 $\mathrm{m}$ high) has a very slender (but rigidly erect) peduncle and branches. Racemes are lax, cylindrical-acuminate and $15-30 \mathrm{~cm}$ long, with pedicels $6-15 \mathrm{~mm}$ long. Flowers are dull to somewhat glossy red or orange, 30-40 $\mathrm{mm}$ long and with a globose basal swelling (7-9 $\mathrm{mm}$ diameter).

Conservation status. Least Concern (Raimondo et al. 2009). 


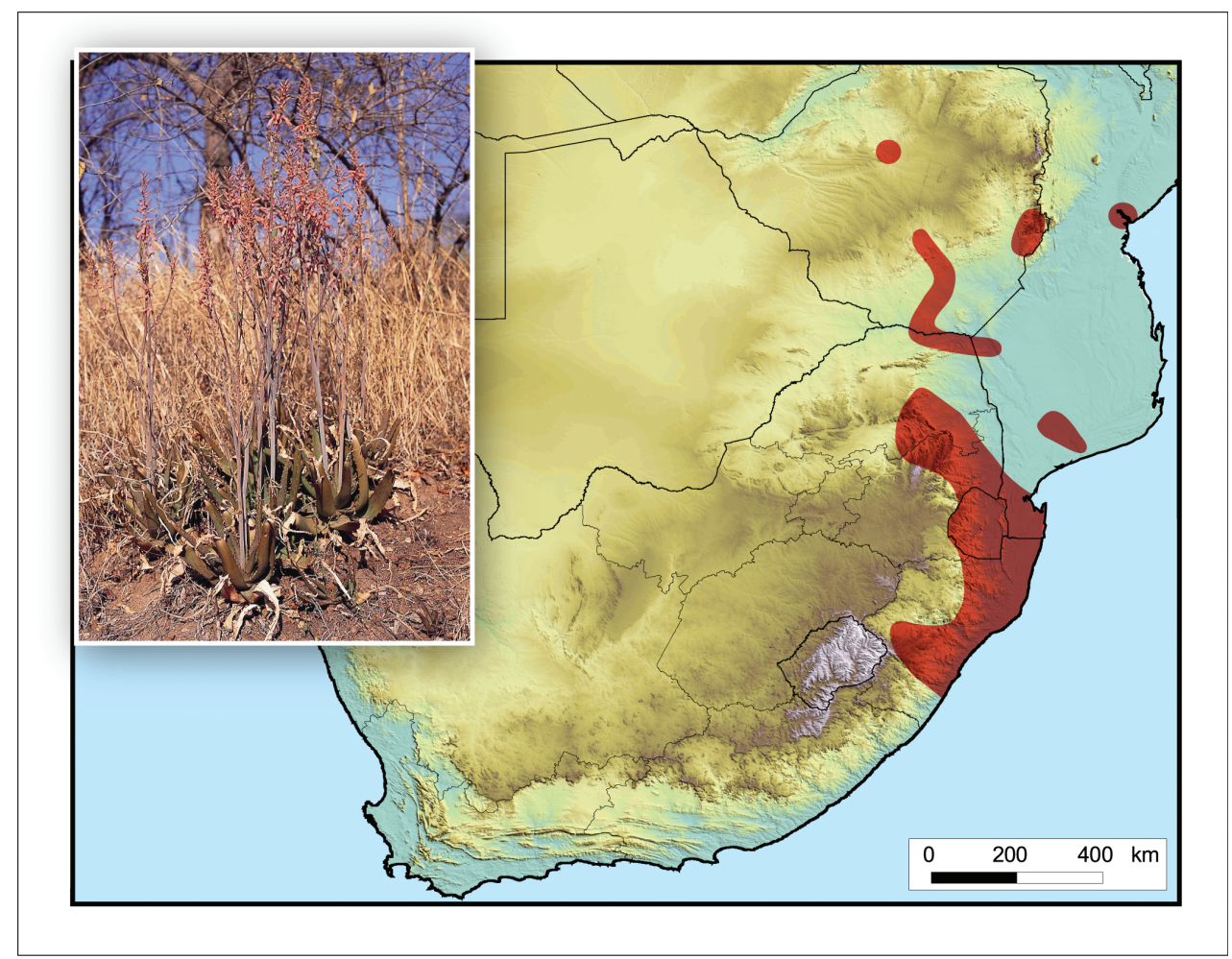

Figure 30. Aloe parvibracteata. Photo: G.F. Smith.

Distribution. Northern KwaZulu-Natal, eastern Mpumalanga and Limpopo in South Africa, also in Eswatini, southern Mozambique and Zimbabwe (Fig. 30).

Notes. Until recently, Aloe monteiroae Baker was regarded as an insufficiently known species, since its true identity could not be determined with certainty (see Reynolds 1950 and Carter 2001). The discovery of a population of aloes near Komatipoort, Mpumalanga, that match the description of $A$. monteiroae has enabled Crouch et al. (2015) to confirm that it is conspecific with $A$. parvibracteata. However, A. monteiroae is the older of the two names. To avoid nomenclatural disruptions by allowing a previously unknown name to replace one that has for long been in common use for a widespread aloe, a successful proposal was published to conserve the familiar name Aloe parvibracteata and enable its continued use for this aloe (Klopper et al. 2015; Wilson 2017).

\section{${ }^{\mathrm{E}}$ Aloe parviflora Baker}

Description. Grass aloe. Acaulescent, rosettes solitary, erect. Leaves few, distichous to rosulate, spreading, deciduous, bright green, lower surface with nerves and numerous spinulescent white spots especially towards base, texture tuberculate-muricate, lorate- 


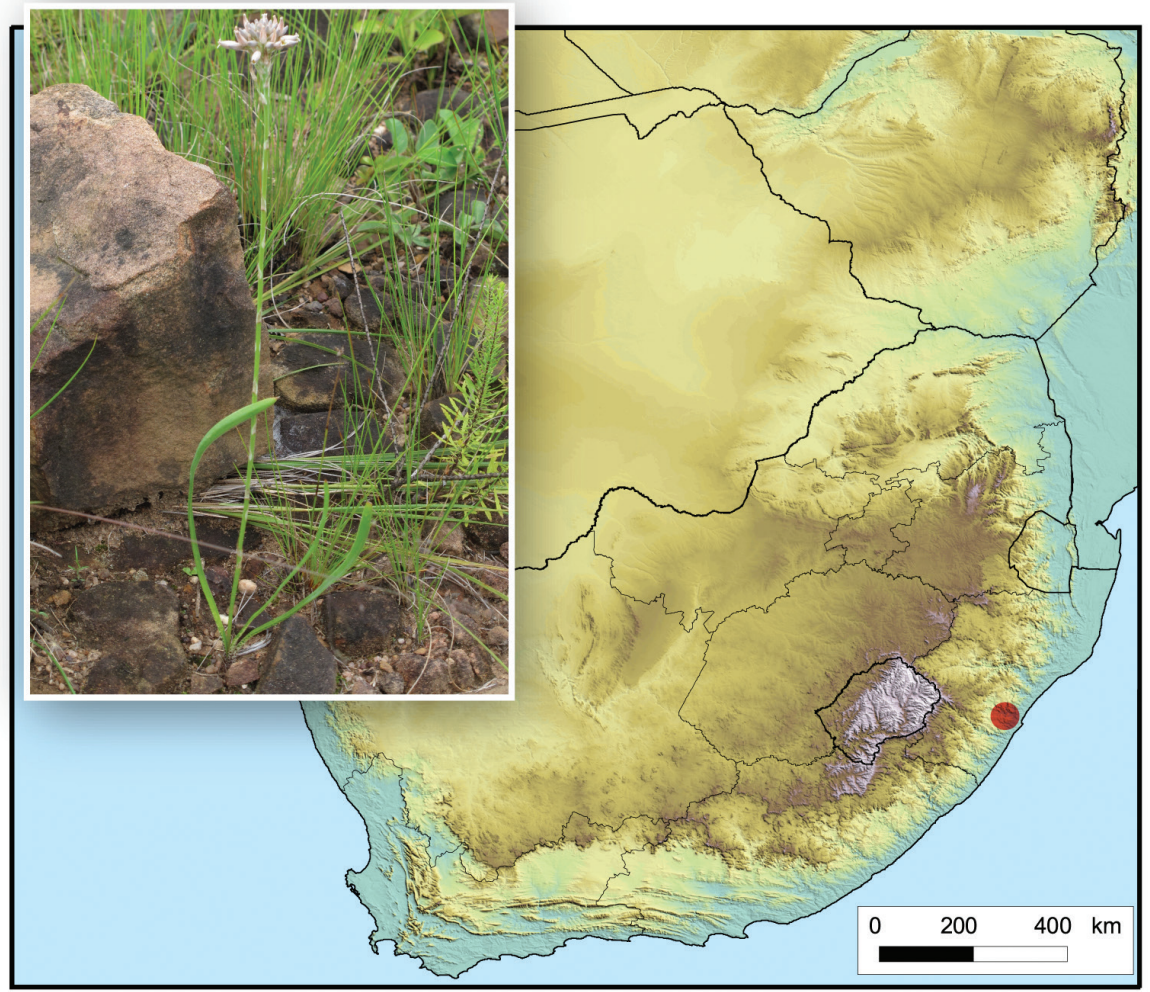

Figure 3 I. Aloe parviflora. Photo: N.R. Crouch.

linear, attenuate at base, apex obtuse, $20-25 \mathrm{~cm}$ long, $0.6-0.8 \mathrm{~cm}$ wide; margin ciliate with minute white crowded teeth; exudate clear. Inflorescence $0.4 \mathrm{~m}$ high, erect, simple. Raceme capitate, $\pm 3 \mathrm{~cm}$ long, $3 \mathrm{~cm}$ wide, dense. Floral bracts $8-12 \mathrm{~mm}$ long. Pedicels $8-12 \mathrm{~mm}$ long. Flowers: perianth pale rose, $8 \mathrm{~mm}$ long, widening slightly towards middle, narrowing towards mouth, straight or slightly decurved, shortly cylindrical; outer segments free to base; stamens and style not exserted.

Flowering time. January-March.

Habitat. Short grassland, on level or gently sloping areas on the summit of hills, in shallow soil over exposed sloping sandstone rock sheets and in rocky places with thin soil and sparse grass.

Diagnostic characters. Aloe parviflora can be distinguished from other grass aloes in KwaZulu-Natal with unkeeled leaves that are usually narrower than $3.5 \mathrm{~cm}$ and that lack a bulb-like underground swelling (Aloe dominella, Aloe linearifolia, Aloe micracantha, Aloe minima, Aloe nicholsii and Aloe saundersiae), by the distichous to rosulate, spreading, lorate-linear leaves $(20-25 \times 0.6-0.8 \mathrm{~cm})$ that are distinctly muricate with soft spinulescent white spots on the lower surface. It is further characterised by the 
peduncle, which has numerous small spines on the lower part. The unbranched inflorescences ( $0.4 \mathrm{~m}$ high) have dense, capitate racemes with pedicels $8-12 \mathrm{~mm}$ long and very small, pale rose flowers ( $8 \mathrm{~mm}$ long). Rosettes are solitary.

Conservation status. Vulnerable. Threats include habitat loss and degradation owing to urban expansion, as well as alien invasives, overgrazing and incorrect fire management (L. von Staden pers. comm.).

Distribution. Confined to a small area between Pinetown and Cato Ridge in central KwaZulu-Natal, South Africa (Fig. 31).

Notes. Aloe parviflora is sometimes considered to be conspecific with Aloe minima Baker (Glen and Hardy 2000).

\section{Aloe pluridens Haw.}

Common names. French aloe, many-toothed tree-aloe (English); fransaalwyn (Afrikaans).

Description. Tree or shrub, up to $3 \mathrm{~m}$ high. Stem $\pm 2-3 \mathrm{~m}$ high, can reach up to $5 \mathrm{~m}$, simple or branched at ground level or from middle or above, erect, with persistent dried leaves in upper half. Leaves densely rosulate, erectly spreading and gracefully recurved, sometimes falcately deflexed, pale to yellowish-green, obscurely lineate, lanceolate-falcate, 60-70 cm long, 5-6 cm wide at base; margin narrow, white, cartilaginous, with deltoid, incurved, white or very pale pink teeth, 2-3 mm long, 5-10 mm apart; exudate clear. Inflorescence $0.8-1.0 \mathrm{~m}$ high, erect, up to 4-branched from below middle. Racemes conical, 25-30 cm long, dense. Floral bracts $\pm 20 \mathrm{~mm}$ long, 10-12 mm wide. Pedicels 30-35 mm long. Flowers: perianth salmon pink to orange to dull scarlet or yellow, 40-45 $\mathrm{mm}$ long, 6-7 $\mathrm{mm}$ across ovary, slightly constricted above ovary, slightly widening towards mouth, cylindrical-trigonous; outer segments free to base; stamens exserted 2-4 $\mathrm{mm}$; style exserted to $5 \mathrm{~mm}$.

Flowering time. May-June.

Habitat. Succulent thicket vegetation on hillside slopes within a coastal strip and, in the north of its range, along the ecotone of coastal forest pockets.

Diagnostic characters. Aloe pluridens differs from the other tall often singlestemmed aloes in KwaZulu-Natal (Aloe candelabrum, Aloe marlothii, Aloe rupestris, Aloe spectabilis and Aloe thraskii) with branched inflorescences, by having narrow (60-70 $\times$ 5-6 cm), erectly spreading and gracefully recurved, pale green to yellowish-green, obscurely lineate leaves with small crowded pinkish-white marginal teeth and exudate with a distinct sharp odour. The inflorescence is up to 4-branched with erect, rather lax, conical racemes of 25-30 cm long. Flowers are salmon-pink to orange to dull scarlet or yellow and 40-45 mm long. Note though that the flowers of $A$. pluridens never take on the bright scarlet colour of some forms of $A$. arborescens.

Conservation status. Least Concern (Raimondo et al. 2009).

Distribution. This species has a disjunct distribution range. It occurs from the Humansdorp area to the Kei River Mouth in the Eastern Cape, as well as in the Durban area in KwaZulu-Natal, South Africa (Fig. 32; Walker et al. 2019a). 


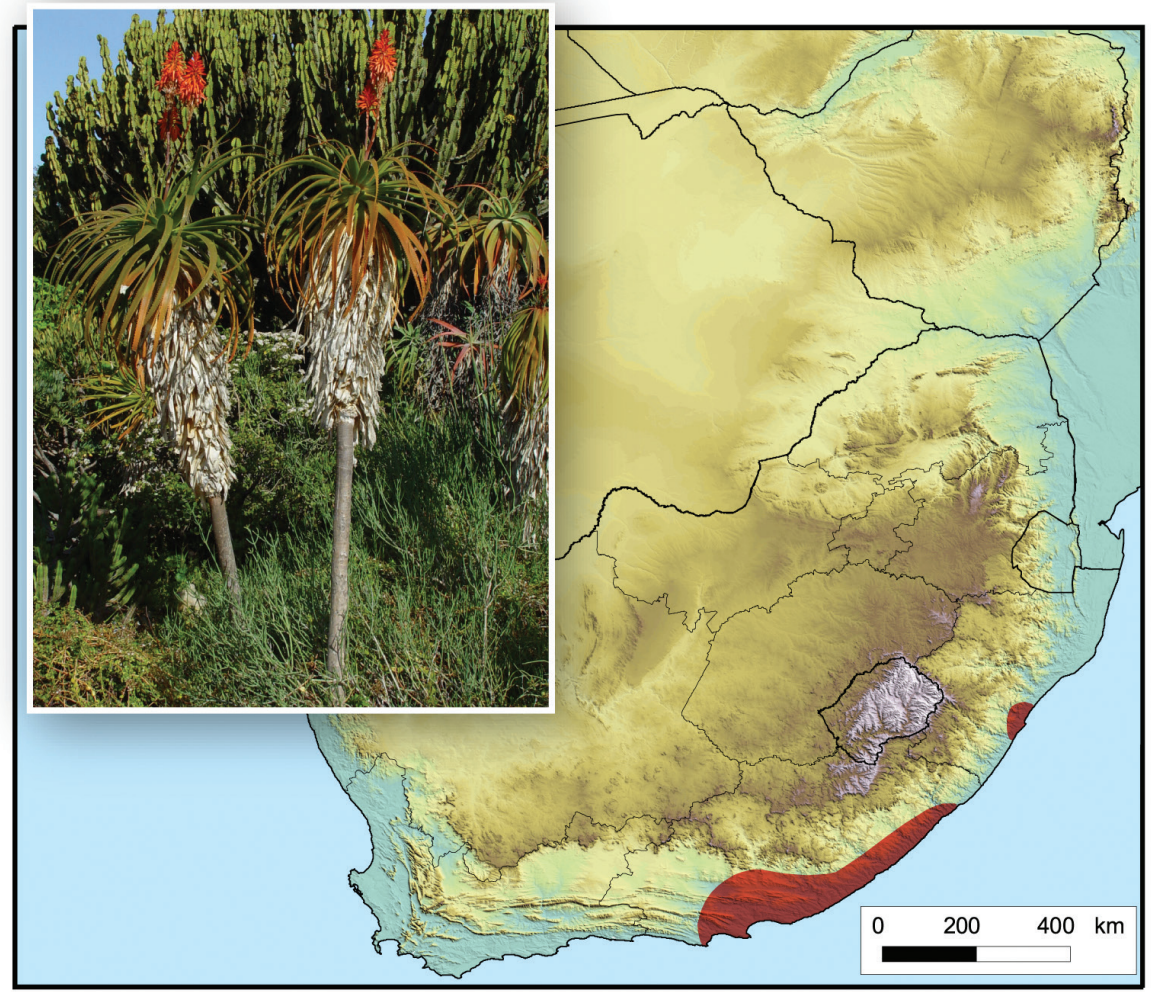

Figure 32. Aloe pluridens. Photo: G. Nichols.

\section{Aloe pratensis Baker}

Common names. Meadow aloe (English); bergaalwyn (Afrikaans).

Description. Acaulescent plants; rosettes solitary or branching from the base to form small groups, 15-25 cm diameter. Leaves densely rosulate, erectly spreading to slightly incurved, glaucous, lineate, deltoid-lanceolate, 10-17 cm long, 4-6 cm wide, lower surface with few scattered red-brown spines from white tuberculate bases, keel armed with few brown spines, 2-3 mm long; margin not distinctly coloured, with pungent, deltoid, reddish-brown teeth, $\pm 5 \mathrm{~mm}$ long, $\pm 10 \mathrm{~mm}$ apart; exudate clear, drying deep orange. Inflorescence $0.5-0.6 \mathrm{~m}$ high, erect, simple; peduncle almost entirely covered with large, thin, imbricate sterile bracts. Racemes cylindrical, $\pm 20 \mathrm{~cm}$ long, dense; buds completely hidden by large bracts. Floral bracts up to $40 \mathrm{~mm}$ long, 15-18 mm wide. Pedicels 25-40 mm long. Flowers: perianth rose-red, 35-40 mm long, $\pm 5 \mathrm{~mm}$ across ovary, slightly enlarged towards mouth, basally stipitate, cylindrical; outer segments free to base; stamens exserted 0-1 $\mathrm{mm}$; style exserted 1-2 mm.

Flowering time. August-December. 


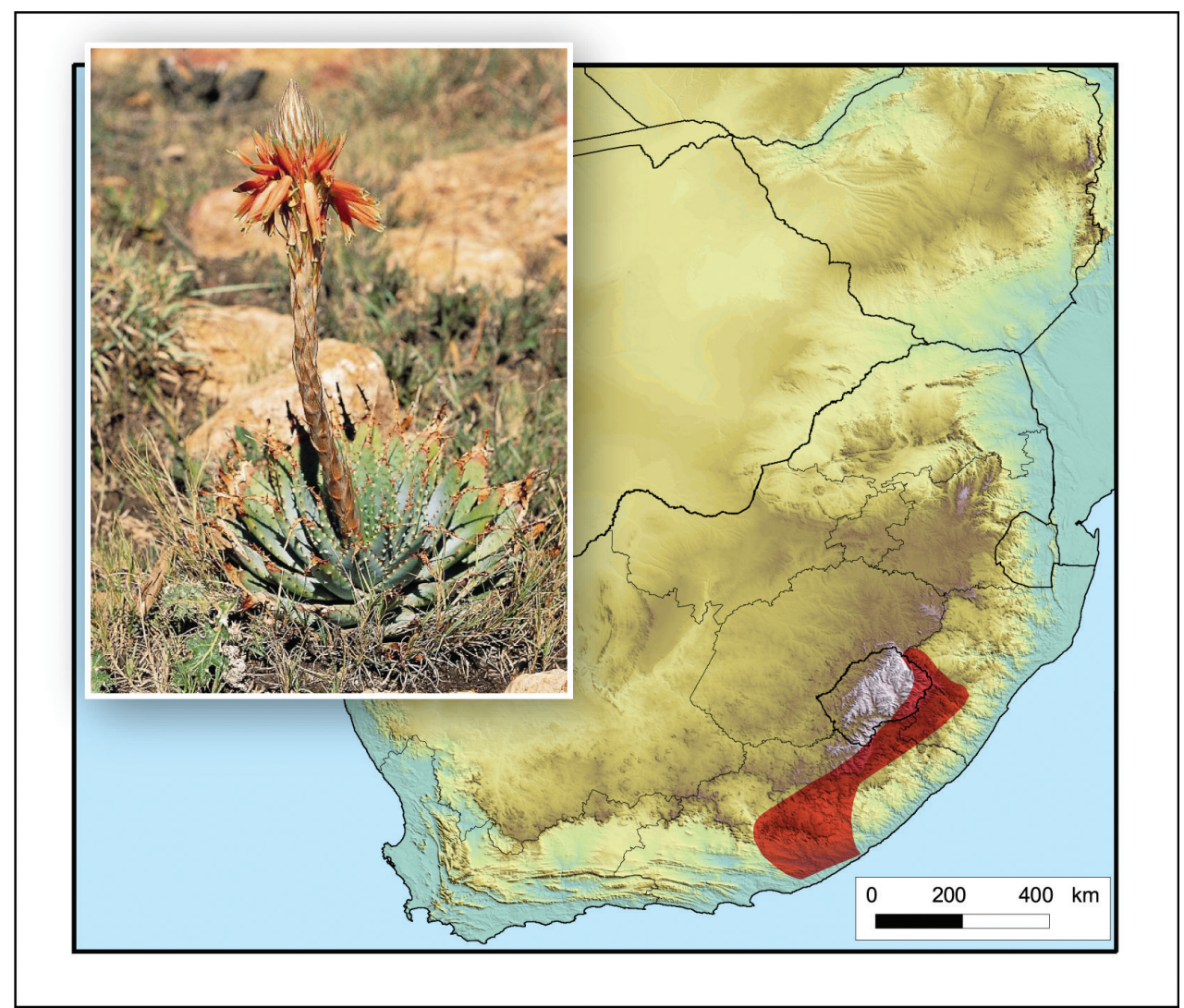

Figure 33. Aloe pratensis. Photo: G.F. Smith.

Habitat. In exposed positions amongst rocks in sloping montane grassland in some of the coldest parts of the southern Drakensberg.

Diagnostic characters. Aloe pratensis can easily be distinguished from other KwaZulu-Natal aloes by being an acaulescent plant with smallish rosettes $( \pm 20 \mathrm{~cm}$ diameter) that occurs solitary or in small groups. Leaves $(10-17 \times 4-6 \mathrm{~cm})$ have pungent reddish-brown marginal teeth $( \pm 5 \mathrm{~mm}$ long) and spines on the lower surface that arise from white tuberculate bases. The inflorescence $(0.5-0.6 \mathrm{~m}$ high) is simple with the peduncle covered in large, imbricate bracts. Racemes are cylindrical and dense and elongates significantly as flowering progresses, although the length of the peduncle stays roughly constant. Flower buds are hidden by large floral bracts. Flowers are cylindrical and rose-red (35-40 $\mathrm{mm}$ long).

Conservation status. Least Concern (Raimondo et al. 2009).

Distribution. It occurs in the central and northern Eastern Cape and along the Great Escarpment and in south-western KwaZulu-Natal along the Drakensberg Mountain Range to Royal Natal National Park, South Africa, as well as Lesotho (Fig. 33). 


\section{${ }^{\mathrm{E}}$ Aloe prinslooi I.Verd. \& D.S.Hardy}

Common names. Spotted aloe (English); bontaalwyn (Afrikaans).

Description. Acaulescent plants, $0.15-0.25 \mathrm{~m}$ high; rosettes usually solitary, erect. Leaves rosulate, suberect to spreading, light green, with white, oblong spots, denser on upper surface, occasionally arranged in transverse bands, shortly deltoid, 14-20 cm long, 4-8 cm wide; margin with pungent brown teeth, $\pm 4 \mathrm{~mm}$ long, 5-7 $\mathrm{mm}$ apart; exudate clear. Inflorescence up to $0.6 \mathrm{~m}$ high, erect, 2- to 5-branched above middle. Racemes corymbose-capitate, 6-12 cm long, 6-7 cm wide, dense. Floral bracts 15$30 \mathrm{~mm}$ long, 3-5 mm wide. Pedicels $12-30 \mathrm{~mm}$ long. Flowers: perianth pale whitishgreen, tinged with pale to deep pink, 13-17 mm long, sometimes slightly narrowing above ovary, widening towards slightly upturned mouth, cylindrical; outer segments free for 5-7 mm; stamens exserted 0-1 mm; style slightly or not exserted.

Flowering time. June-October.

Habitat. Dense grass understorey of open woodland in KwaZulu-Natal midlands on thin soil. More rarely in open, rocky outcrops. Rainfall relatively low, summers hot and winters very cold.

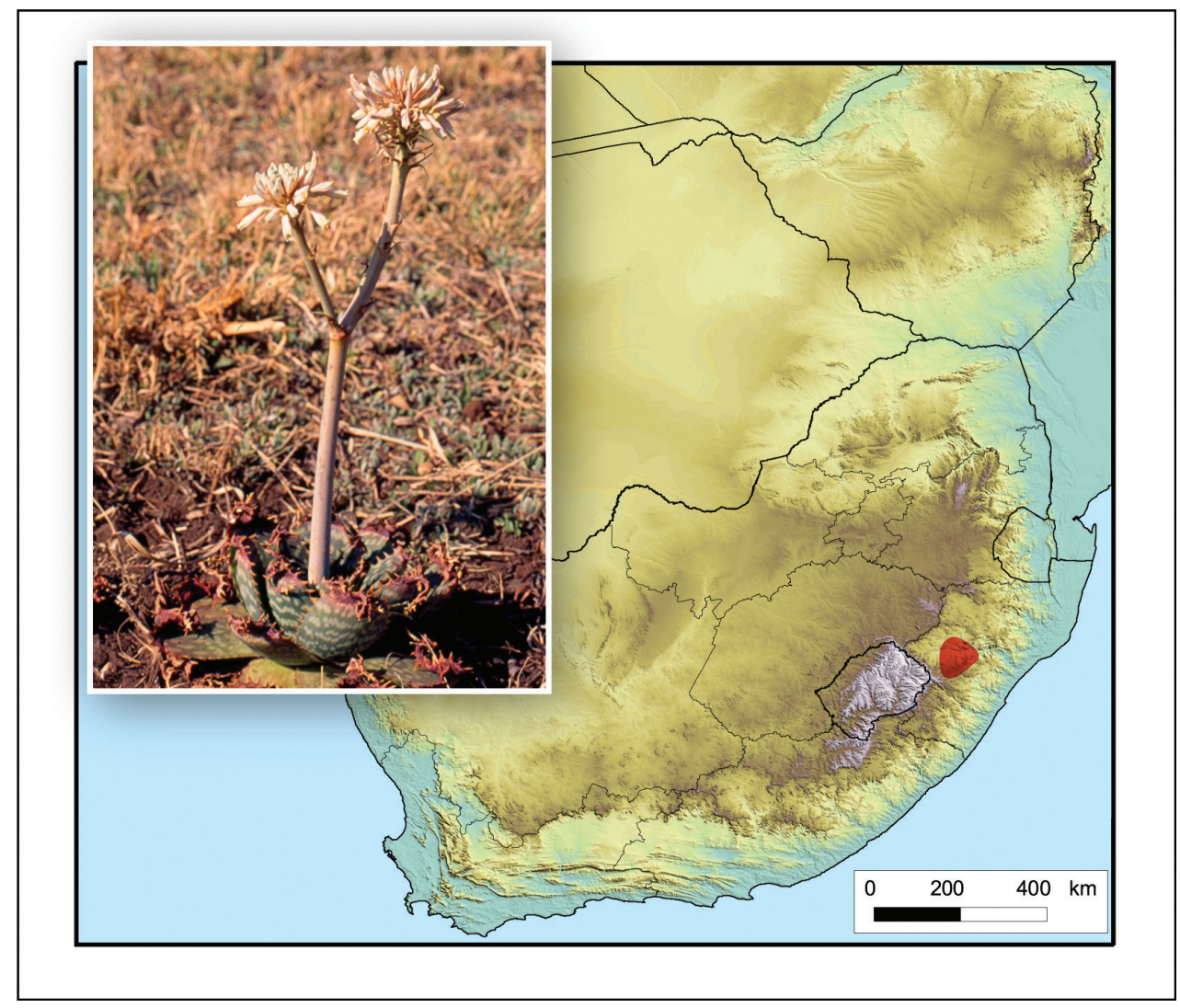

Figure 34. Aloe prinslooi. Photo: P. Joffe. 
Diagnostic characters. Aloe prinslooi can be distinguished from other maculate aloes in KwaZulu-Natal (Aloe dewetii, Aloe maculata subsp. maculata, Aloe mudenensis, Aloe parvibracteata, Aloe pruinosa, Aloe suffulta, Aloe umfoloziensis, Aloe vanrooyenii and Aloe viridiana) by its short, 2- to 5-branched inflorescence (up to $0.6 \mathrm{~m}$ high) with almost spherical, very dense racemes $(6-12 \times 6-7 \mathrm{~cm})$ of creamish to pinkish-white flowers (up to $17 \mathrm{~mm}$ long) that lack the distinctive globose basal swelling typical of the maculate aloes. Pedicels are $12-30 \mathrm{~mm}$ long. Leaves are suberect to spreading, 14-20 $\times 4-8 \mathrm{~cm}$ and spotted on both surfaces, with the spots being denser on the upper surface. Marginal teeth are $\pm 4 \mathrm{~mm}$ long.

Conservation status. Endangered. Threats include trampling by livestock and too frequent fires. In the past, populations were negatively impacted by illegal collecting (Raimondo et al. 2009, L. von Staden pers. comm.).

Distribution. Limited to an area near Colenso in the KwaZulu-Natal midlands, South Africa (Fig. 34).

\section{${ }^{\mathrm{E}}$ Aloe pruinosa Reynolds}

Common names. Kleinaalwyn, slangkop (Afrikaans); icena elihkulu (Zulu).

Description. Shortly caulescent plant, $0.25-0.60 \mathrm{~m}$ tall. Stem up to $0.5 \mathrm{~m}$, unbranched, procumbent; rosettes solitary, erect. Leaves densely rosulate, erectly spreading to slightly recurved, bright green, with numerous white, somewhat $\mathrm{H}$-shaped spots, scattered or confluent in wavy, irregular, interrupted, transverse bands, spots more numerous and in more defined transverse bands on lower surface, lanceolate-attenuate, 50-70 cm long, 8-10 cm wide at base; margin with deltoid, pungent, pale pinkishbrown teeth, 3-4 mm long, 15-20 mm apart; exudate honey-coloured, drying deep purple. Inflorescence $1.4-2.0 \mathrm{~m}$ high, erect, \pm 11 -branched above middle. Racemes cylindrical-acuminate, terminal up to $30 \mathrm{~cm}$ long, $7 \mathrm{~cm}$ wide, lateral shorter, usually 10-12 cm long, lax. Floral bracts 10-20 mm long. Pedicels $10-20 \mathrm{~mm}$ long. Flowers: perianth dull dark brownish-red to pinkish white, with heavy grey powdery bloom, 30-40 mm long, $8 \mathrm{~mm}$ across ovary, abruptly constricted above ovary to form globose basal swelling, widening towards mouth, sharply decurved, laterally compressed; outer segments free for 5-7 mm; stamens exserted 1-2 $\mathrm{mm}$; style exserted 1-4 mm.

Flowering time. February-March.

Habitat. In shade in acacia savannah in KwaZulu-Natal midlands on heavy loam in areas of fairly high summer rainfall.

Diagnostic characters. Aloe pruinosa can be distinguished from other maculate aloes in KwaZulu-Natal (Aloe dewetii, Aloe maculata subsp. maculata, Aloe mudenensis, Aloe parvibracteata, Aloe prinslooi, Aloe suffulta, Aloe umfoloziensis, Aloe vanrooyenii and Aloe viridiana) by the tall, \pm 11-branched inflorescence $(1.4-2.0 \mathrm{~m}$ high) with the peduncle and flowers that are very heavily coated with a greyish powdery substance. The flowers, which are dull dark brownish-red to pinkish-white, 30-40 $\mathrm{mm}$ long and with a globose basal swelling ( $8 \mathrm{~mm}$ diameter), have the most pronounced powdery-covered leaves and 


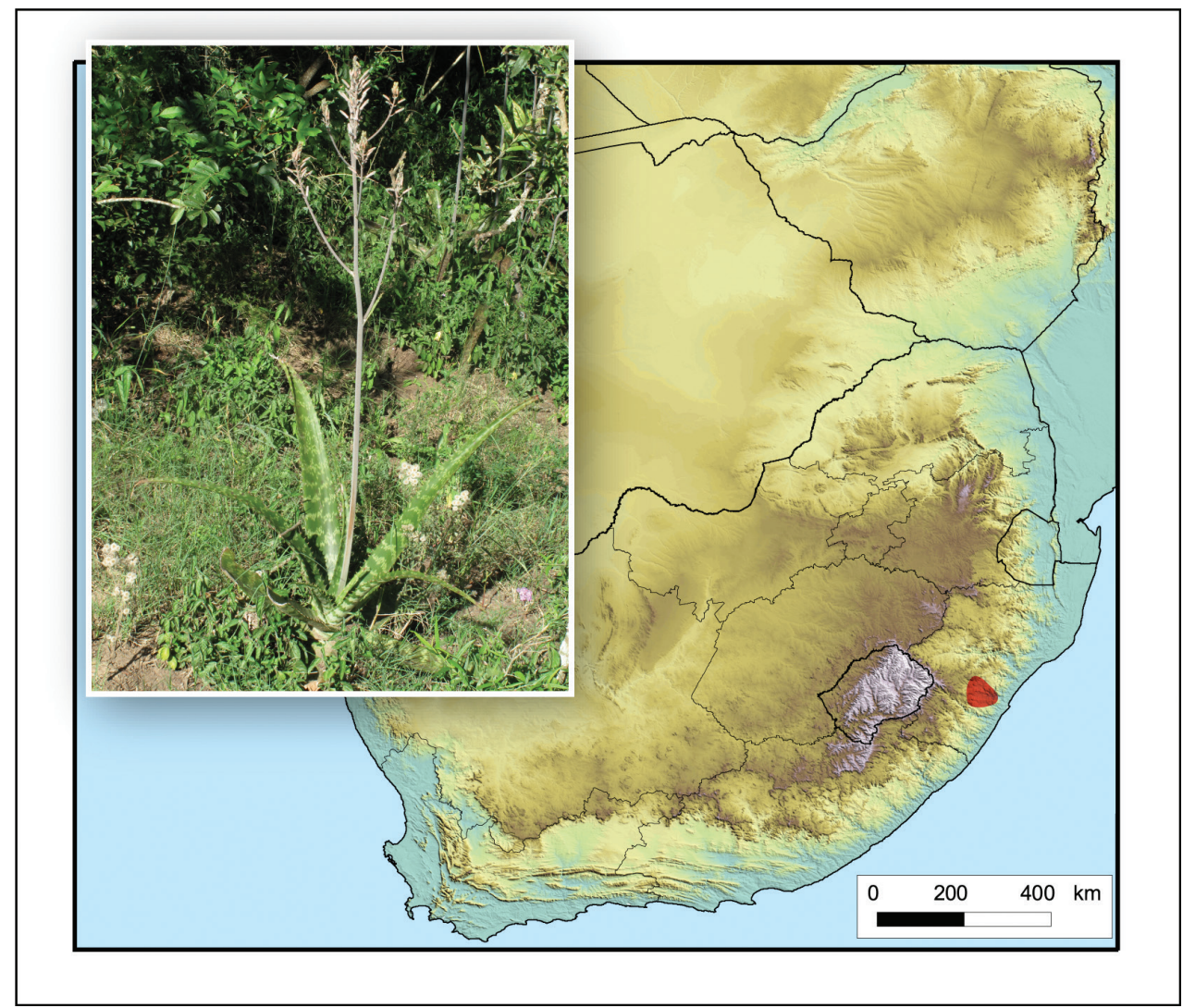

Figure 35. Aloe pruinosa. Photo: N.R. Crouch.

inflorescence of all South African aloe species. It is further characterised by the erectly spreading to slightly recurved leaves $(50-70 \times 8-10 \mathrm{~cm})$ that are spotted on both surfaces, with the spots more pronounced on the lower surface. Marginal teeth are $3-4 \mathrm{~mm}$ long. The lax racemes are cylindrical-acuminate, with the terminal one the longest (up to $30 \times 7 \mathrm{~cm}$ ) and the lateral ones usually 10-12 cm long (Smith et al. 1999).

Conservation status. Endangered. Threats include urban expansion and harvesting for use in traditional medicine (Raimondo et al. 2009, L. von Staden pers. comm.).

Distribution. Occurs from Pietermartizburg to Durban and northwards to the uThukela (Tugela) River valley, KwaZulu-Natal, South Africa (Fig. 35).

\section{${ }^{\mathrm{E}}$ Aloe reitzii Reynolds var. vernalis $\mathrm{D}$.S.Hardy}

Common names. Reitz's spring aloe (English); lente-bergaalwyn (Afrikaans).

Description. Acaulescent plants or rarely with short stem of up to $0.5 \mathrm{~m}$, simple, rarely branched, procumbent; rosette solitary, erect. Leaves densely rosulate, arcuateerect, dull green, without spots, texture smooth, lanceolate-ensiform, 40-65 cm long, 


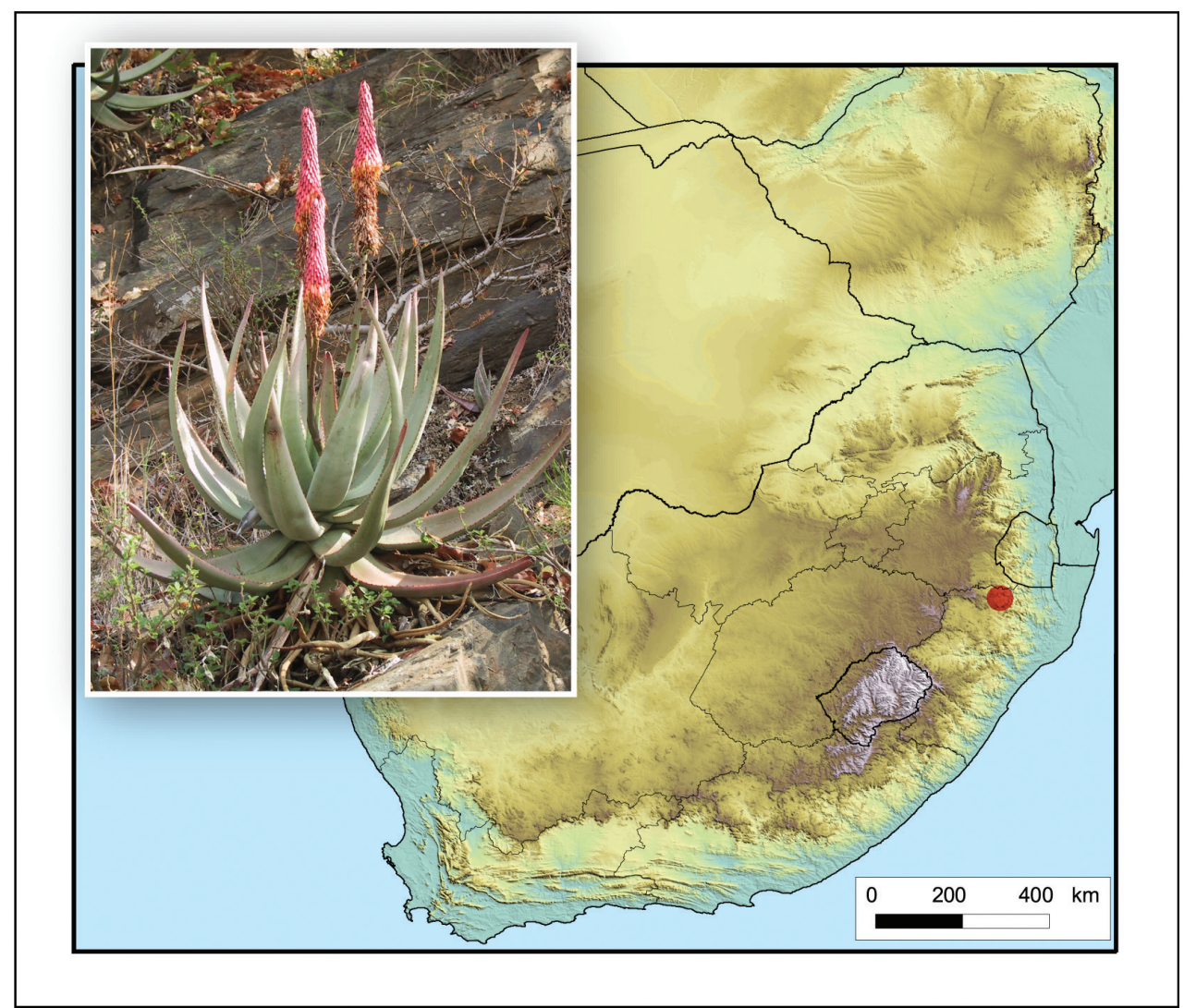

Figure 36. Aloe reitzii var. vernalis. Photo: E. van Wyk.

5-9 cm wide, lower surface sometimes with brownish spines in median line near apex, leaf tip armed with pungent spine; margin not distinctly coloured, with deltoid, pungent, brownish to reddish-brown teeth from distinct white base, $\pm 3 \mathrm{~mm}$ long, $\pm 5 \mathrm{~mm}$ apart; exudate drying bright yellow. Inflorescence $0.70-0.75 \mathrm{~m}$ high, erect, 2- to 4-branched from below middle. Racemes cylindrical, slightly acuminate, $30-40 \mathrm{~cm}$ long, $5-6 \mathrm{~cm}$ wide, very dense, with open flowers pendent and pressed against the peduncle. Floral bracts $\pm 6 \mathrm{~mm}$ long, $4-5 \mathrm{~mm}$ wide. Pedicels $3 \mathrm{~mm}$ long. Flowers: perianth dull orangered in bud, turning yellow when flowers open, $32-40 \mathrm{~mm}$ long, $\pm 5 \mathrm{~mm}$ across ovary, enlarging towards middle, slightly narrowing towards mouth, curved-cylindrical; outer segments free for $15 \mathrm{~mm}$; stamens exserted to $8 \mathrm{~mm}$; style exserted to $10 \mathrm{~mm}$.

Flowering time. August-September.

Habitat. Steep well-drained granitic slopes in grassland.

Diagnostic characters. Aloe reitzii var. vernalis can be distinguished from other virtually acaulescent, non-maculate aloes in KwaZulu-Natal (Aristaloe aristata, Aloe chabaudii var. chabaudii, Aloe gerstneri, Aloe pratensis, Aloe suprafoliata and Aloe vanbalenii) by the very dense racemes $(30-40 \times 5-6 \mathrm{~cm})$ with short erect pedicels $(3 \mathrm{~mm})$. 
Flowers are bicoloured (outer part of tube orange-red, inner part yellow), 32-40 mm long, tubular and curved, pointing downwards and pressed against the peduncle, with rather long-exserted stamens and style. Leaves are narrow $(40-65 \times 5-9 \mathrm{~cm})$, arcuateerect, dull green, sometimes with spines on median line of lower surface and with pungent marginal teeth from a distinct white base. Flowering time is in spring.

Conservation status. Vulnerable. Threats include harvesting for medicinal purposes and damage by feeding baboons (Raimondo et al. 2009, L. von Staden pers. comm.).

Distribution. Confined to a small area in the Vryheid District, KwaZulu-Natal, South Africa (Fig. 36).

Notes. The typical variety, $A$. reitzii var. reitzii only occurs in the Belfast District in Mpumalanga, South Africa.

\section{${ }^{\mathrm{NE}}$ Aloe rupestris Baker}

Common names. Bottle-brush aloe (English); borselaalwyn, kraalaalwyn (Afrikaans); inkhalane, umhlabanhlazi, uphondonde (Zulu).

Description. Solitary, arborescent plant. Stem usually unbranched, up to 6-8 m high, erect, with persistent dried leaves in upper third only. Leaves densely rosulate, erectly spreading to recurved, dull to slightly glossy deep green, without spots, texture smooth, lanceolate-attenuate, $30-70 \mathrm{~cm}$ long, $7-10 \mathrm{~cm}$ wide; margin deep pink to pale red, with stout, pungent, reddish-brown, deltoid teeth, 4-6 mm long, 8-12 mm apart; exudate honey-coloured. Inflorescence 1.0-1.3 m high, erect, 6- to 9-branched from above middle, lower branches rebranched. Racemes cylindrical, very slightly acuminate, somewhat truncate, 20-25 cm long, $7 \mathrm{~cm}$ wide, very dense. Floral bracts $\pm 1 \mathrm{~mm}$ long, $2 \mathrm{~mm}$ wide. Pedicels $1-2 \mathrm{~mm}$ long. Flowers: perianth orange-yellow in bud, green striped in upper half, lemon-yellow in lower third and orange-yellow to brownish-yellow upwards when mature, 15-20 mm long, $4 \mathrm{~mm}$ across ovary, widening slightly towards middle, narrowing at mouth, cylindrical, slightly ventricose; outer segments free for $12 \mathrm{~mm}$; stamens exserted 7-15 mm; style exserted 7-20 mm.

Flowering time. August-September.

Habitat. Zululand thornveld, coastal plain on sandy soils, sometimes dense bush, usually on rocky outcrops. Areas with warm, completely frost-free winters. Usually found in groups amongst trees.

Diagnostic characters. Aloe rupestris differs from the other tall often singlestemmed aloes in KwaZulu-Natal (Aloe candelabrum, Aloe marlothii, Aloe pluridens, Aloe spectabilis and Aloe thraskii) with branched inflorescences, by having wide (30$70 \times 7-10 \mathrm{~cm}$ ), erectly spreading to recurved leaves that lack surface prickles and have pungent, reddish-brown marginal teeth. The inflorescence is 6- to 9-branched and rebranched with up to 20 erect, very dense, cylindrical, very slightly acuminate and somewhat truncate racemes of $20-25 \mathrm{~cm}$ long. Flowers are almost sessile, lemon-yellow to brownish-yellow and 15-20 mm long. The long-exserted deep orange to dark red stamens and style emerge from the flowers straight (not at an angle as in Aloe thraskii). 


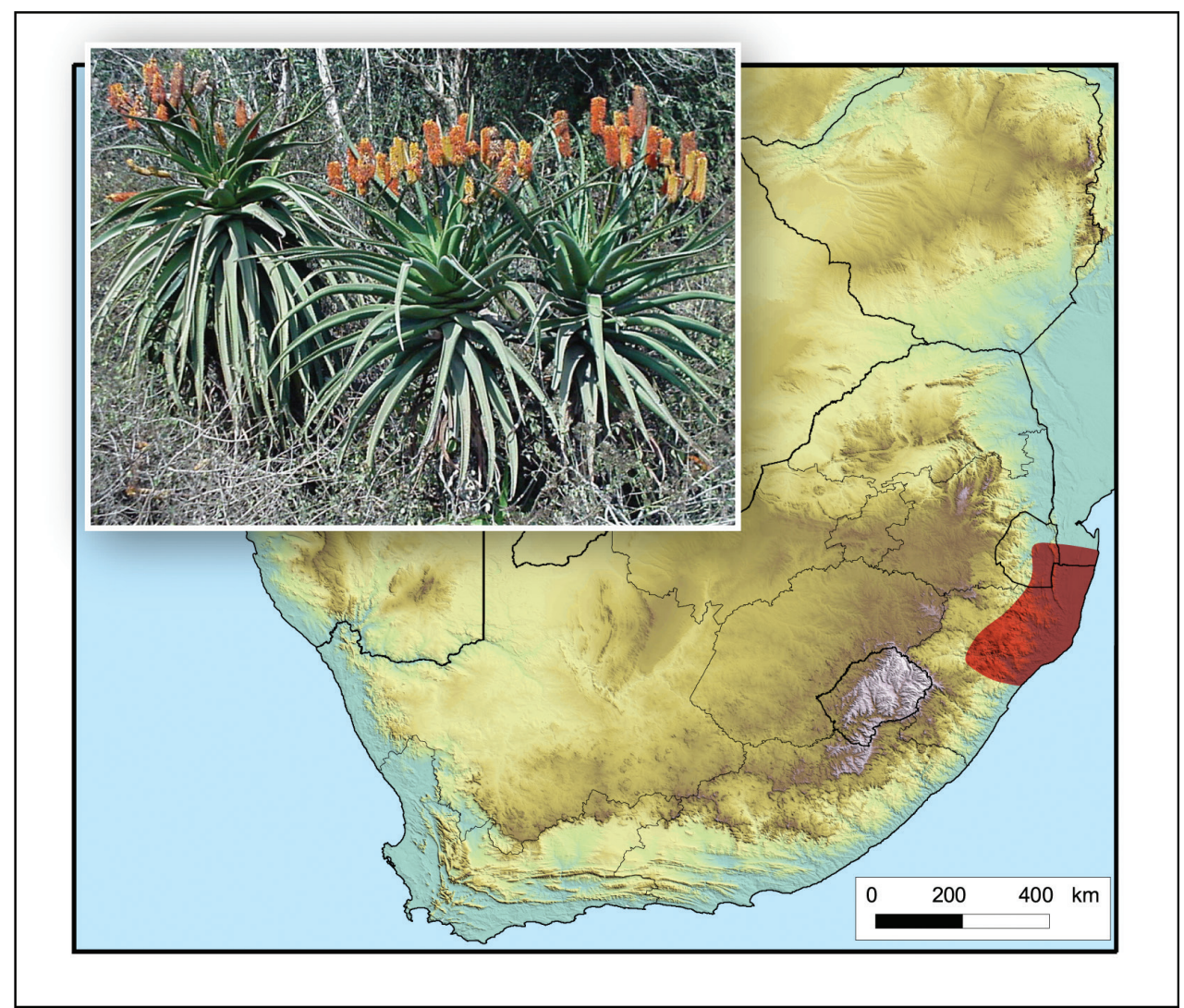

Figure 37. Aloe rupestris. Photo: G. Nichols.

Conservation status. Least Concern (Raimondo et al. 2009).

Distribution. Central to northern KwaZulu-Natal in South Africa, eastern Eswatini and southern Mozambique (Fig. 37).

\section{${ }^{\mathrm{E}}$ Aloe saundersiae (Reynolds) Reynolds}

Description. Acaulescent grass aloe, 0.05-0.075 m high; rosettes solitary or suckering to form small tufted groups. Leaves rosulate, widely spreading to recurved, deciduous, green, without spots or with few white spots near base on lower surface, narrowly linear, 4-10 cm long, $0.3 \mathrm{~cm}$ wide, basally amplexicaul and $1 \mathrm{~cm}$ wide below ground; margin with rather soft, white, deltoid teeth, $\pm 0.5 \mathrm{~mm}$ long, $1 \mathrm{~mm}$ apart; exudate clear. Inflorescence $0.14-0.18 \mathrm{~m}$ high, erect, simple. Raceme capitate, $2.0-2.5 \mathrm{~cm}$ long, 3.0-3.5 mm wide, dense. Floral bracts $7 \mathrm{~mm}$ long, 3-4 mm wide. Pedicels 8-10 mm long. Flowers: perianth pale cream-pink, 9-12 mm long, 3-4 mm across ovary, narrowing towards slightly upturned mouth, cylindrical-trigonous, slightly ventricose; outer segments free to base; stamens and style not exserted. 


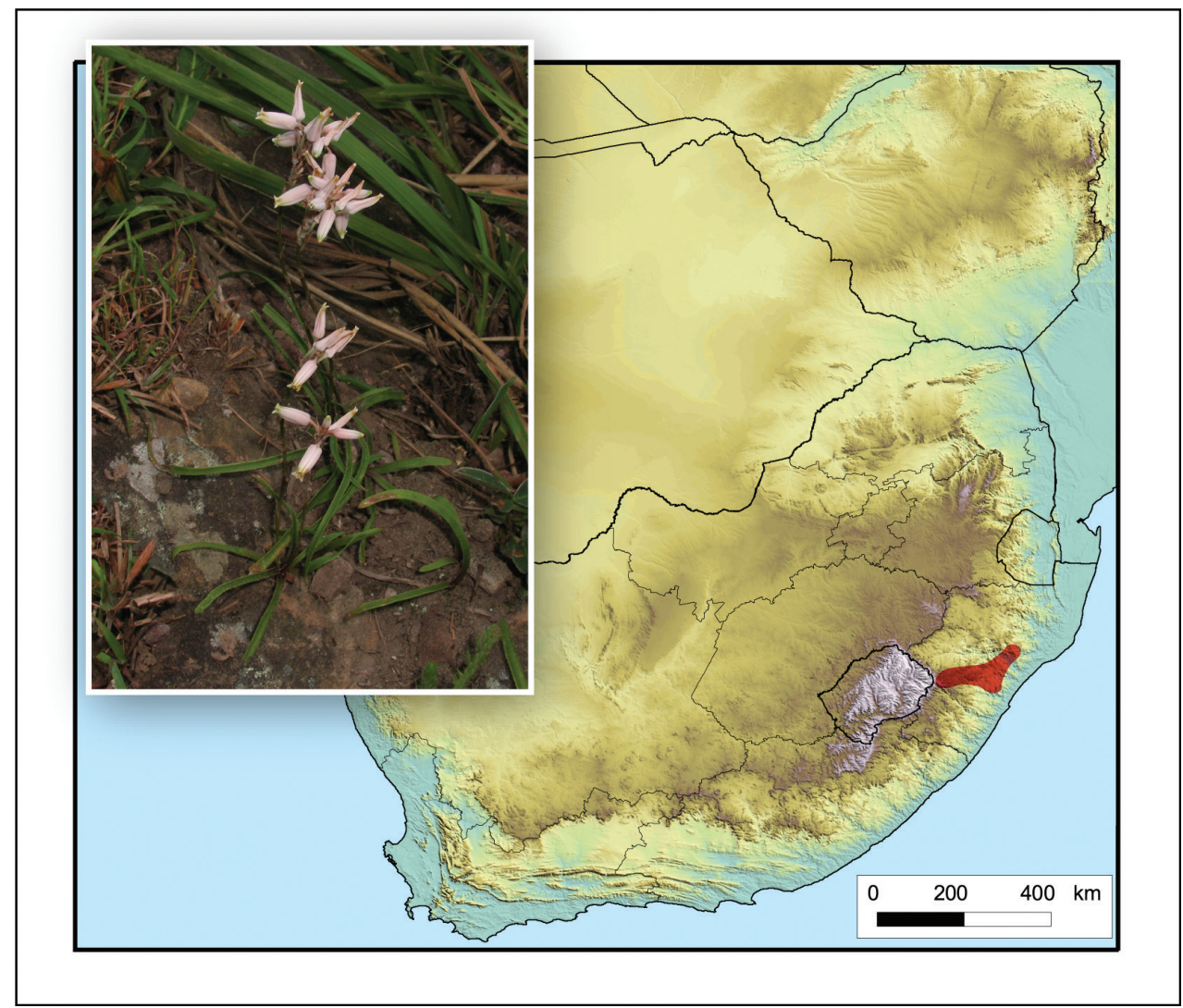

Figure 38. Aloe saundersiae. Photo: N.R. Crouch.

Flowering time. February-March.

Habitat. Rocky outcrops in rock crevices and clumps of moss or in flat exposed places in short rocky grassland on mountain tops, in rich black soil.

Diagnostic characters. Aloe saundersiae can be distinguished from other grass aloes in KwaZulu-Natal with unkeeled leaves that are usually narrower than $3.5 \mathrm{~cm}$ and that lack a bulb-like underground swelling (Aloe dominella, Aloe linearifolia, Aloe micracantha, Aloe minima, Aloe nicholsii and Aloe parviflora), by its rosulate, spreading to recurved leaves $(4-10 \times 0.3 \mathrm{~cm})$ that are without spots or with a few white spots near the base on the lower surface. The unbranched inflorescences $(0.14-0.18 \mathrm{~m}$ high) have dense, capitate racemes of small, pale pinkish flowers (9-12 $\mathrm{mm}$ long), with the mouth slightly upturned and with spreading tips, but not bilabiate. Pedicels are $8-10 \mathrm{~mm}$ long. Rosettes are solitary or in small tufted groups.

Conservation status. Endangered. Threats include overgrazing and too frequent fires (Raimondo et al. 2009, L. von Staden pers. comm.).

Distribution. Only known from the central parts of KwaZulu-Natal, South Africa (Fig. 38). 


\section{${ }^{\mathrm{NE}}$ Aloe sharoniae N.R.Crouch \& Gideon F.Sm.}

Syn. Aloe cooperi subsp. pulchra Glen \& D.S.Hardy.

Common names. Sharon's grass aloe (English); sharonse-grasaalwyn (Afrikaans)

Description. Grass aloe, $0.30-0.65 \mathrm{~m}$ high. Acaulescent plants or stem up to $0.15 \mathrm{~m}$, erect, usually solitary, rarely with offshoots at ground level to form small groups, dried leaves not persistent. Leaves distichous, semi-erect to decurved, deciduous, green, usually without spots on upper surface, with copious white tubercles each bearing a hair-like process at base on lower surface, obscurely lineate, narrowly attenuate, 30-44(-82) cm long, 1.6-2.6(-3.9) $\mathrm{cm}$ wide at base, distinctly keeled, strongly $\mathrm{V}$-shaped in cross section; margin narrow, white, cartilaginous, with rubbery, hair-like, ivory to greenish-white teeth in basal quarter to third only, 3-5 $\mathrm{mm}$ long, 1-2 mm apart at mid-leaf; exudate clear, drying clear. Inflorescences 0.33 $0.59 \mathrm{~m}$ high, erect, simple. Raceme capitate to slightly elongate, 3.0-9.5 cm long, $7.5-9.5 \mathrm{~cm}$ wide, dense. Floral bracts $23-30 \mathrm{~mm}$ long, 6-8 $\mathrm{mm}$ wide, clasping the pedicel. Pedicels 33-43 mm long. Flowers: perianth bright orange-red, yellowish-

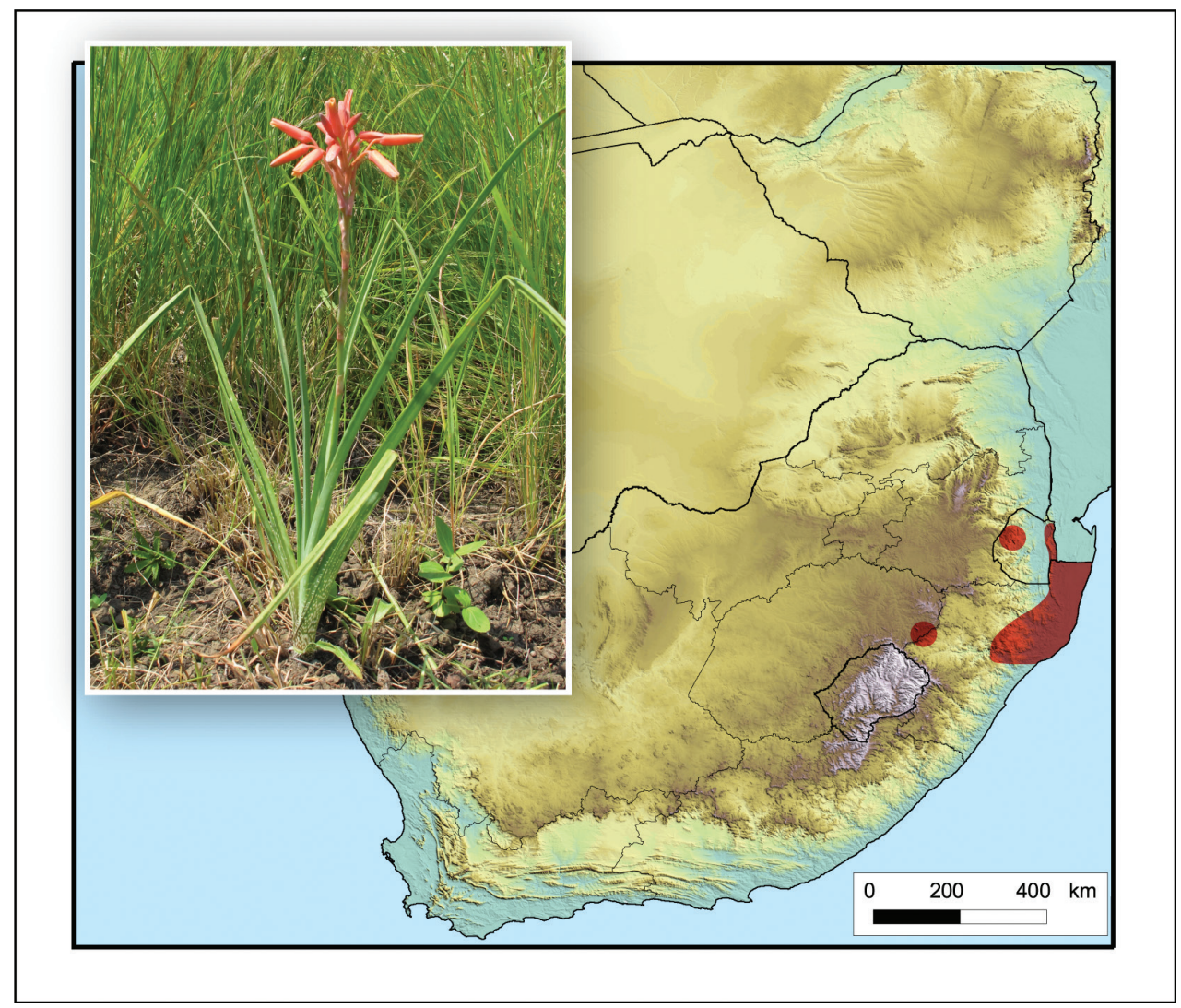

Figure 39. Aloe sharoniae. Photo: N.R. Crouch. 
brown to purplish-brown tipped, $25-35 \mathrm{~mm}$ long, 6-8 $\mathrm{mm}$ across ovary, narrowing towards mouth, roundly trigonous, basally stipitate and narrowing into pedicel; outer segments free almost to base; stamens not or very slightly exserted; style only slightly exserted.

Flowering time. February-March.

Habitat. Open grassland on all slope aspects.

Diagnostic characters. Aloe sharoniae is distinguished from other grass aloes in KwaZulu-Natal with strongly keeled leaves (Aloe cooperi and Aloe myriacantha) by the distichous leaves (30-44 cm long) that have no marginal teeth in the upper $2 / 3$ and that are basally covered with white tuberculate maculations on the lower surface. It is further characterised by the floral bracts that clasp the pedicels (not flat as in Aloe cooperi). The inflorescence $(0.33-0.59 \mathrm{~m})$ is longer than the leaves. Flowers are bright orange-red, yellowish-brown to purplish-brown tipped and $25-35 \mathrm{~mm}$ long, with the mouth not bilabiate or upturned.

Conservation status. Least Concern (Von Staden 2014b).

Distribution. Sparse. Limited to KwaZulu-Natal, South Africa and Eswatini, although this species may also occur in southern Mozambique (Fig. 39).

\section{${ }^{\mathrm{E}}$ Aloe spectabilis Reynolds}

Common names. Natal aloe (English); natalaalwyn (Afrikaans); umhlaba (Zulu).

Description. Solitary, arborescent plant up to $5 \mathrm{~m}$ high. Stem simple, rarely forked high up, erect, up to $4 \mathrm{~m}$ high, densely covered with persistent dried leaves. Leaves densely rosulate, suberect to spreading and eventually pendent, dull green, sometimes reddish tinged, without spots, usually with copious spines on both leaf surfaces, lanceolate-ensiform, $\pm 100 \mathrm{~cm}$ long, $12-15 \mathrm{~cm}$ wide at base; margin with stout, pungent, reddish to brownish teeth, 5-7 mm long, 10-20 mm apart; exudate honey-coloured. Inflorescence erect, much-branched, lower branches rebranched. Racemes cylindrical, rather truncate, $\pm 25 \mathrm{~cm}$ long, 9-10 cm wide, erect to suberect, dense. Floral bracts 4-5 mm long, $5 \mathrm{~mm}$ wide. Pedicels $\pm 3 \mathrm{~mm}$ long. Flowers: perianth yellow to goldenyellow, buds with slightly redder tinge, $\pm 32 \mathrm{~mm}$ long, $\pm 5 \mathrm{~mm}$ wide across ovary, enlarging above ovary, narrowing towards mouth, slightly decurved; outer segments free for $\pm 15 \mathrm{~mm}$; stamens and style exserted $20 \mathrm{~mm}$.

Flowering time. June-August.

Habitat. Wide variety of habitats, including rocky places and open situations in grassland and savannah on hills.

Diagnostic characters. Aloe spectabilis differs from the other tall often singlestemmed aloes in KwaZulu-Natal (Aloe candelabrum, Aloe marlothii, Aloe pluridens, Aloe rupestris and Aloe thraskii) with branched inflorescences, by having large $( \pm 100 \times$ $12-15 \mathrm{~cm}$ ), suberect to spreading, eventually pendent leaves that usually have copious spines on both surfaces and pungent, reddish to brownish marginal teeth. The inflorescence is much-branched and rebranched with erect to suberect, very dense, cylindrical, 


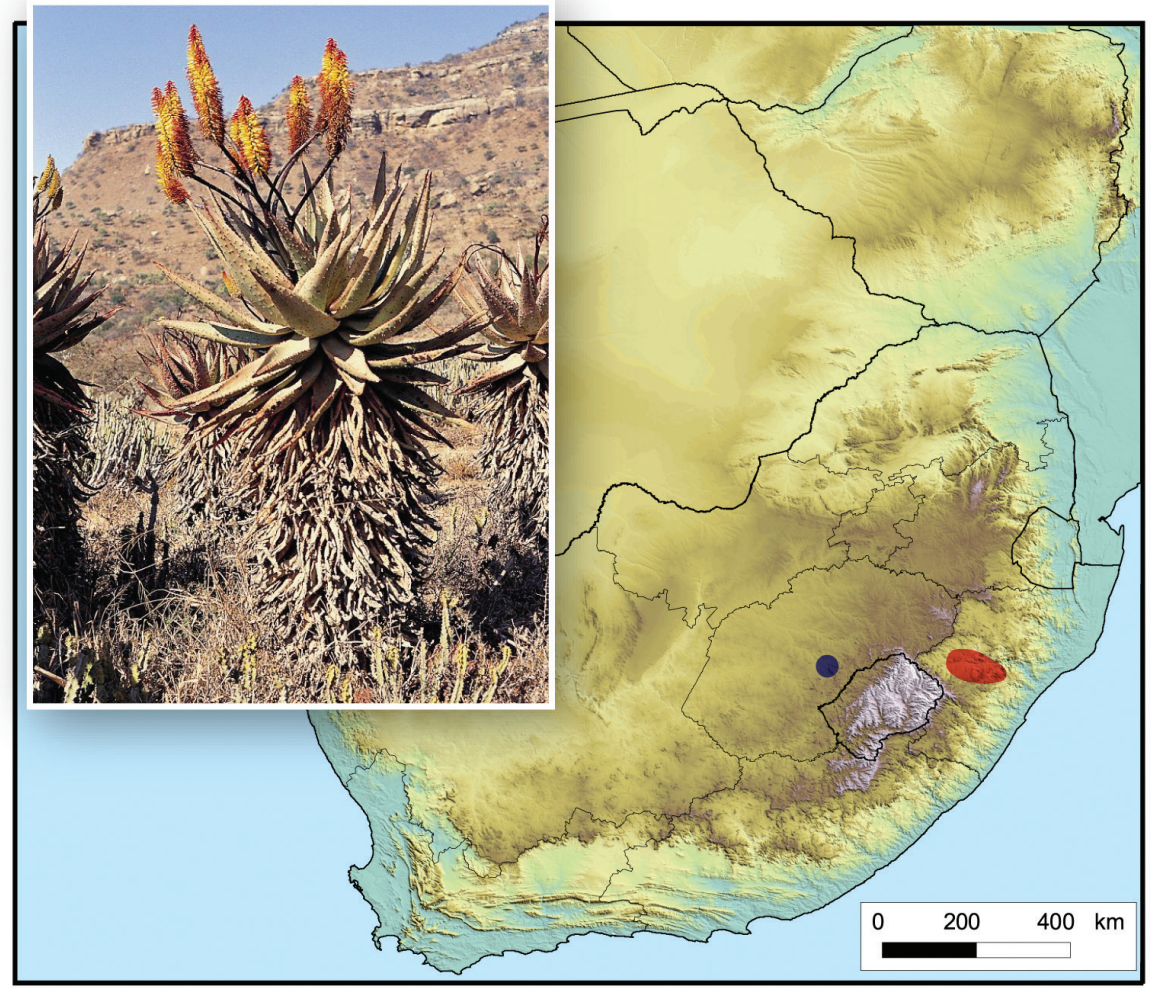

Figure 40. Aloe spectabilis. Photo: G.F. Smith.

rather truncate racemes of $\pm 25 \mathrm{~cm}$ long. Flowers are golden-yellow to reddish tinged and $\pm 32 \mathrm{~mm}$ long with the inner segment tips dull to glossy deep purplish-black to black and the exserted portion of the stamens orange (not with purplish segment tips and deep purple filaments as in Aloe marlothii).

Conservation status. Least Concern (Raimondo et al. 2009).

Distribution. Occurs in a small area in west-central KwaZulu-Natal, South Africa. Plants on the farm Bester Schrik, Winburg, Free State, South Africa, $5 \mathrm{~km}$ north of the Korannaberg, are a naturalised population (blue on map; Fig. 40) (For more details see Klopper et al. 2010).

\section{Aloe spicata L.f.}

Syn. Aloe sessiliflora Pole Evans.

Common names. Lebombo aloe (English); Lebombo-aalwyn (Afrikaans); inhlaba (Zulu). 


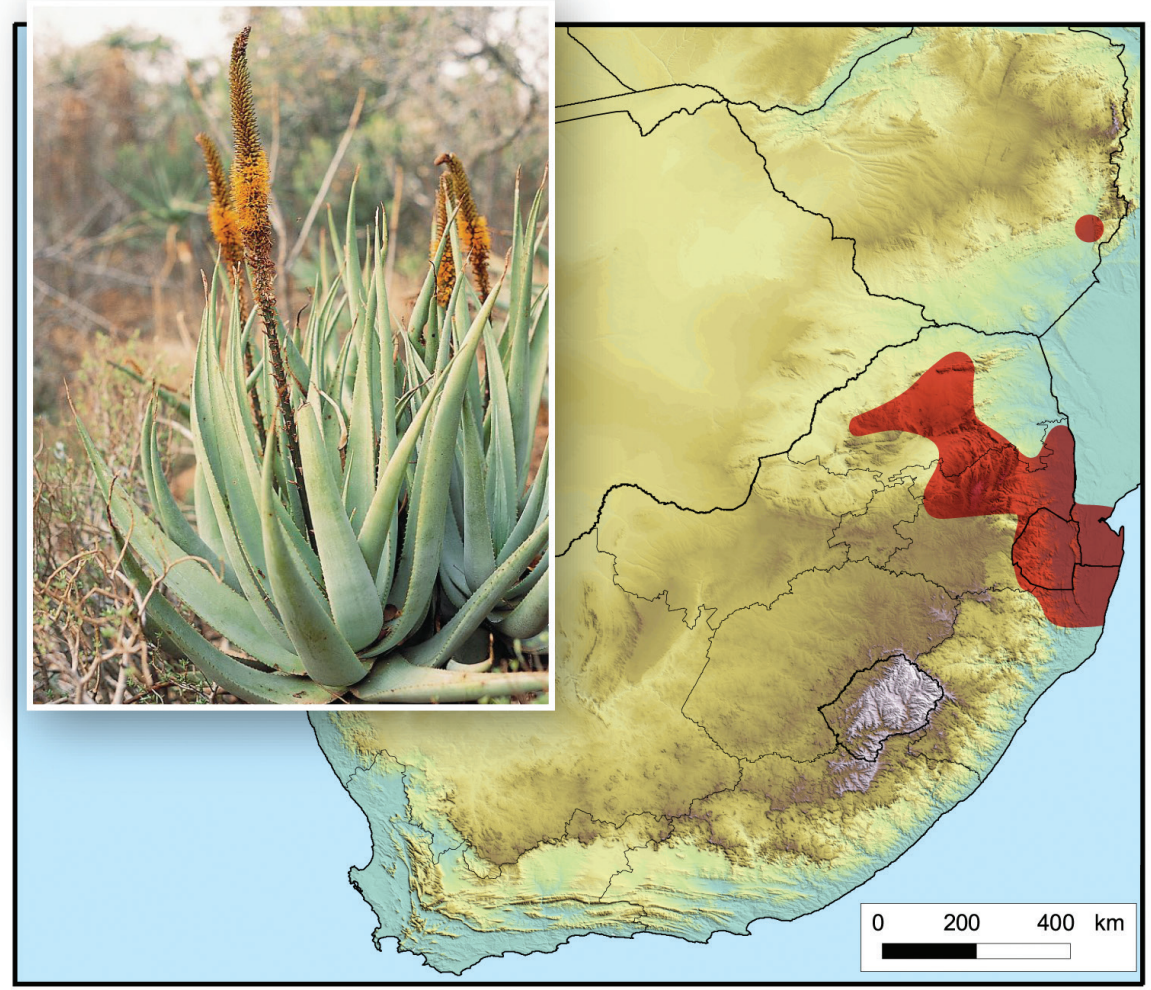

Figure 4I. Aloe spicata. Photo: G.F. Smith.

Description. Acaulescent to arborescent or shrubby plants. Stem 1-2 m high, unbranched or branched low down or high up, erect to decumbent, with persistent dried leaves. Leaves densely rosulate, spreading to slightly recurved, green to sometimes almost entirely reddish on upper surface, without markings, lanceolate-attenuate, canaliculate, 50-80 cm long, 7-10 cm wide; margin reddish, with small deep pink to reddish teeth, 1-2 mm long, 8-15 mm apart; exudate pale honey-coloured. Inflorescence 0.6-1.2 m high, erect, simple. Raceme cylindrical, 30-50 cm long, 4-5 cm diameter, very dense. Floral bracts $\pm 10 \mathrm{~mm}$ long, $6 \mathrm{~mm}$ wide. Pedicels absent. Flowers: perianth buds pale brownish-red, greenish-yellow when mature, 14-15 mm long, 5-6 mm across ovary, widening towards wide open mouth, campanulate; outer segments free to base; stamens exserted to $10 \mathrm{~mm}$; style exserted 10-12 $\mathrm{mm}$.

Flowering time. June-August.

Habitat. Wide variety of soils and habitats, including steep rocky slopes and cliffs. It is never found in exposed situations in deep soil.

Diagnostic characters. Aloe spicata is one of only two aloes indigenous to KwaZulu-Natal that have sessile campanulate flowers with dark nectar in a simple inflores- 
cence. It differs from Aloe vryheidensis in often being acaulescent in KwaZulu-Natal or sometimes having erect to decumbent stems (not procumbent), spreading to recurved leaves (not erect) and an erect inflorescence (not oblique). Racemes of Aloe spicata are narrow (4-5 cm wide) with greenish-yellow flowers (not pinkish-brown). The ovary is uniformly green (without red lines).

Conservation status. Least Concern (Raimondo et al. 2009).

Distribution. Northern KwaZulu-Natal, Mpumalanga and Limpopo in South Africa, also throughout Eswatini and in southern Mozambique, with an isolated record in Zimbabwe (Fig. 41).

\section{Aloe suffulta Reynolds}

Common names. Sand aloe, climbing flower aloe (English); sandaalwyn (Afrikaans).

Description. Shortly caulescent plants; rosettes solitary or sometimes suckering to form dense groups. Stem $0.1-0.2 \mathrm{~m}$ long, decumbent, with persistent dried leaves. Leaves loosely rosulate to cauline dispersed, spreading and recurved, dark glossy green, with dull white spots, spots sometimes irregularly scattered, usually more or less arranged in series of interrupted undulating transverse bands, larger and more confluent on lower surface, lanceolate-attenuate, $40-50 \mathrm{~cm}$ long, $2.5-4.0 \mathrm{~cm}$ wide at base; sheath $5-10 \mathrm{~mm}$ long, striatulate, light green, not auriculate; margin with whitish teeth, 1-2 mm long, 5-10 mm apart; exudate pale honey-coloured. Inflorescence 1-2 m high, supported by shrubs, 5- to 9-branched. Racemes cylindrical, slightly acuminate, terminal $\pm 15 \mathrm{~cm}$ long, lateral $\pm 8 \mathrm{~cm}$ long, lax. Floral bracts $4-6 \mathrm{~mm}$ long, 2-4 mm wide. Pedicels 7-10 mm long. Flowers: perianth salmon-pink, whitish at mouth, $25-35 \mathrm{~mm}$ long, $\pm 6 \mathrm{~mm}$ across ovary, slightly narrowed above ovary, enlarging towards wide-open mouth, slightly curved, cylindrical-trigonous; outer segments free for $7 \mathrm{~mm}$; stamens exserted to $6 \mathrm{~mm}$; style exserted to $8 \mathrm{~mm}$.

Flowering time. June-July.

Habitat. Under bushes, in sand with loose humus, on heavy black clay soils or on termite mounds, in very hot places. Very susceptible to cold.

Diagnostic characters. Aloe suffulta can be distinguished from other maculate aloes in KwaZulu-Natal (Aloe dewetii, Aloe maculata subsp. maculata, Aloe mudenensis, Aloe parvibracteata, Aloe prinslooi, Aloe pruinosa, Aloe umfoloziensis, Aloe vanrooyenii and Aloe viridiana) by the 5- to 9-branched, climbing inflorescence (1-2 $\mathrm{m}$ high) with its very slender peduncle (7-9 $\mathrm{mm}$ diameter) that is supported by surrounding bushes. It is further characterised by the spreading and recurved, green deeply channelled leaves $(40-50 \times 2.5-4.0 \mathrm{~cm}$ ) that are laxly rosulate to cauline dispersed (with striatulate sheaths) and are spotted on both surfaces, with marginal teeth 1-2 mm long. Flowers are salmon-pink, $25-35 \mathrm{~mm}$ long and lack the distinctive globose basal swelling of the maculate aloes. Pedicels are $7-10 \mathrm{~mm}$ long.

Conservation status. Least Concern (Raimondo et al. 2009). 


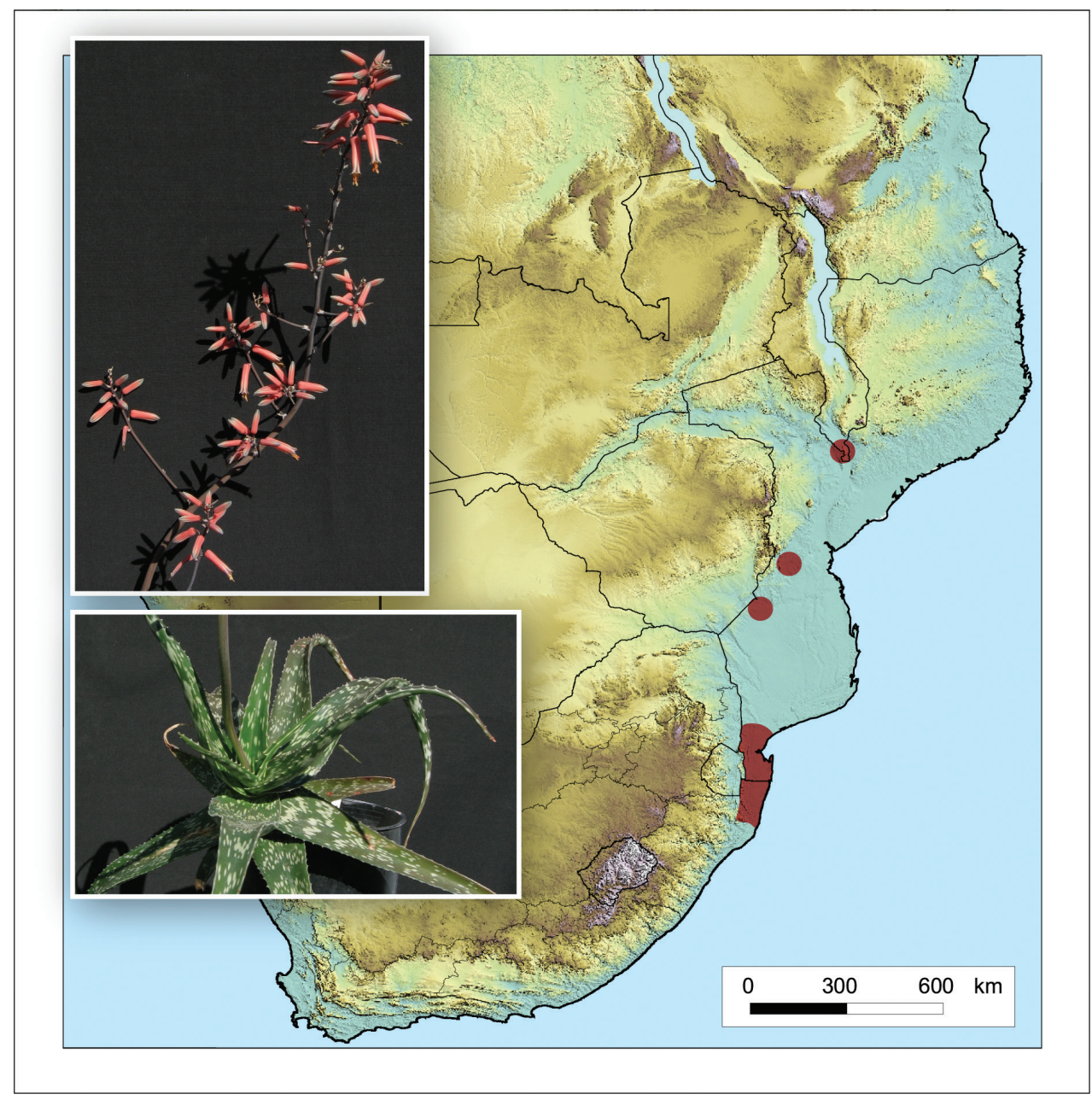

Figure 42. Aloe suffulta. Photos: J.B. Miller.

Distribution. Widespread but infrequent, from northern KwaZulu-Natal, South Africa, through the coastal plains of southern Mozambique, to south-eastern Zimbabwe and southern Malawi (Fig. 42).

\section{${ }^{\mathrm{NE}}$ Aloe suprafoliata Pole-Evans}

Common names. Book aloe (English); boekaalwyn (Afrikaans); icena, umhlabandlazi (Zulu).

Description. Acaulescent plants or rarely with short stem, up to $0.5 \mathrm{~m}$ high, erect or procumbent; rosettes solitary, sometimes in small groups. Leaves distichous in young plants becoming densely rosulate, widely spreading to recurved, bluish-green 


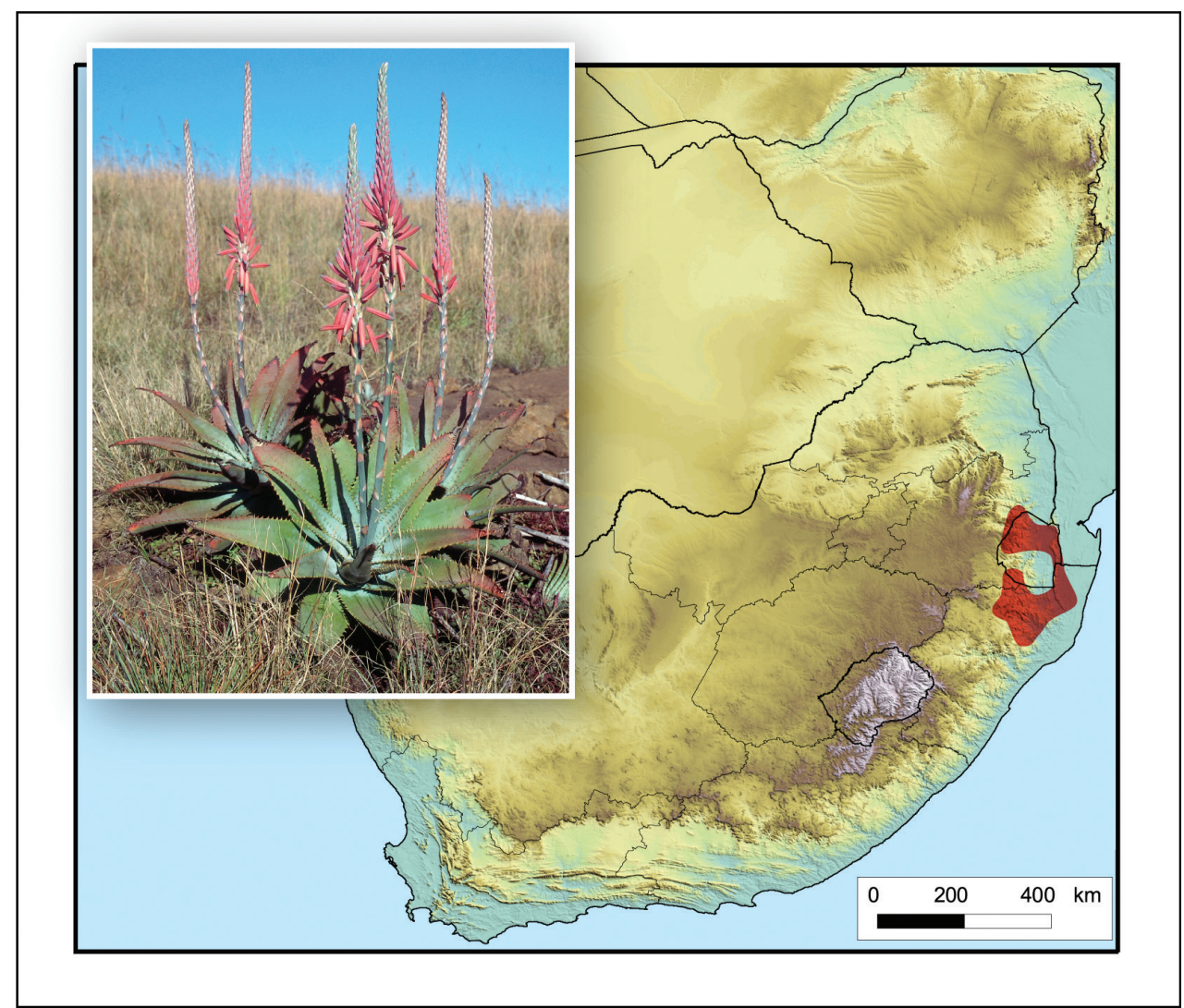

Figure 43. Aloe suprafoliata. Photo: N.R. Crouch.

to bluish-grey, more milky bluish-grey on lower surface, turning reddish-brown near apex, unspotted, obscurely lineate, texture smooth, lanceolate-acuminate, $30-40 \mathrm{~cm}$ long, 5-7 cm wide, with $\pm 8 \mathrm{~cm}$ dried twisted apex; margin with deltoid, sometimes bifid, reddish-brown teeth, 2-5 mm long, 5-10 mm apart; exudate clear. Inflorescence $0.6-2.0 \mathrm{~m}$ high, erect, simple. Raceme conical to cylindrical-acuminate, up to $25 \mathrm{~cm}$ long, $10 \mathrm{~cm}$ wide, rather dense. Floral bracts $15-20 \mathrm{~mm}$ long, 9-13 mm wide. Pedicels 14-20 mm long. Flowers: perianth red, blue-grey tipped in bud, becoming rose-pink to scarlet red, greenish tipped, with a bloom, 33-50 mm long, 6-7 mm across ovary and throughout, cylindrical-trigonous, straight; outer segments free to base; stamens not or very slightly exserted; style exserted 1-2 $\mathrm{mm}$.

Flowering time. May-July.

Habitat. Usually occurs in cracks in rocks or near sheer cliffs, along or near top of mountains, on rocks or rocky slopes in montane grassland or in places where soil is virtually absent or too thin to support other vegetation. Most localities receive frequent mist.

Diagnostic characters. Aloe suprafoliata can be distinguished from other virtually acaulescent, non-maculate aloes in KwaZulu-Natal (Aristaloe aristata, 
Aloe chabaudii var. chabaudii, Aloe gerstneri, Aloe pratensis, Aloe reitzii var. vernalis and Aloe vanbalenii) by usually having solitary rosettes with leaves always distichous in young plants, becoming densely rosulate. Although other aloes also have distichous leaves when juveniles, this character persists for longer in A. suprafoliata. It is further characterised by having widely spreading to recurved, bluish-green to bluish-grey leaves $(30-40 \times 5-7 \mathrm{~cm})$ with rather pungent marginal teeth. The inflorescence is erect, $0.6-2.0 \mathrm{~m}$ high and simple. The narrow racemes (up to $25 \times 10 \mathrm{~cm}$ ) have a silvery sheen with the flower buds hidden by large rounded silvery green floral bracts $(15-20 \mathrm{~mm}$ long). Pedicels are erect (14-20 mm). Flowers are rose-pink to scarlet-red, up to $50 \mathrm{~mm}$ long and pencil-shaped.

Conservation status. Least Concern (Raimondo et al. 2009).

Distribution. Northern KwaZulu-Natal and just into eastern Mpumalanga in South Africa, as well as Eswatini (Fig. 43).

\section{${ }^{\mathrm{NE}}$ Aloe thraskii Baker}

Common names. Dune aloe, strand aloe (English); strandaalwyn (Afrikaans); umhlaba (Zulu).

Description. Solitary, arborescent plant, up to $3 \mathrm{~m}$ high. Stem simple, erect, 1-2 m high, can be up to $4 \mathrm{~m}$, with persistent dried leaves. Leaves condensed rosulate, gracefully recurved, dull green to glaucous, without lines or spots, lower surface sometimes with a few spines in median line, lanceolate-attenuate, $160 \mathrm{~cm}$ long, $22 \mathrm{~cm}$ wide at base; margin very thin, narrow, reddish or brownish-red, with small deltoid reddish teeth, $\pm 2 \mathrm{~mm}$ long, 10-20 mm apart; exudate honey-coloured. Inflorescence $0.5-0.8 \mathrm{~m}$ high, erect, 4- to 8-branched. Racemes broadly cylindrical, slightly acuminate, somewhat truncate, up to $25 \mathrm{~cm}$ long, usually shorter, very dense. Floral bracts $9 \mathrm{~mm}$ long, $6 \mathrm{~mm}$ wide. Pedicels 1-2 mm long. Flowers: perianth greenish to orange in buds, lemon-yellow to pale orange when mature, greenish tipped, $\pm 25 \mathrm{~mm}$ long, $\pm 6 \mathrm{~mm}$ across ovary, enlarging towards throat, mouth constricted and upturned, cylindrical, slightly clavate; outer segments free for $\pm 17 \mathrm{~mm}$; stamens exserted $15-20 \mathrm{~mm}$; style exserted to $20 \mathrm{~mm}$.

Flowering time. June-July.

Habitat. Beach dunes, in almost pure sand in low coastal vegetation or taller bush.

Diagnostic characters. Aloe thraskii differs from the other tall, often singlestemmed aloes in KwaZulu-Natal (Aloe candelabrum, Aloe marlothii, Aloe pluridens, Aloe rupestris and Aloe spectabilis) with branched inflorescences, by its strictly coastal habitat and in having long $( \pm 160 \times 22 \mathrm{~cm})$, strongly recurved, deeply channelled leaves with small reddish marginal teeth. The inflorescence is 4- to 8-branched with erect, very dense, broadly cylindrical, slightly acuminate and somewhat truncate racemes of up to $25 \mathrm{~cm}$ long. Flowers are lemon-yellow to pale orange and $\pm 25 \mathrm{~mm}$ long. The long-exserted yellowish-orange stamens and style emerge from the flower at an angle (not straight as in Aloe rupestris).

Conservation status. Near-threatened. Threats include habitat loss owing to urban expansion along the coast, as well as illegal collecting (Raimondo et al. 2009). 


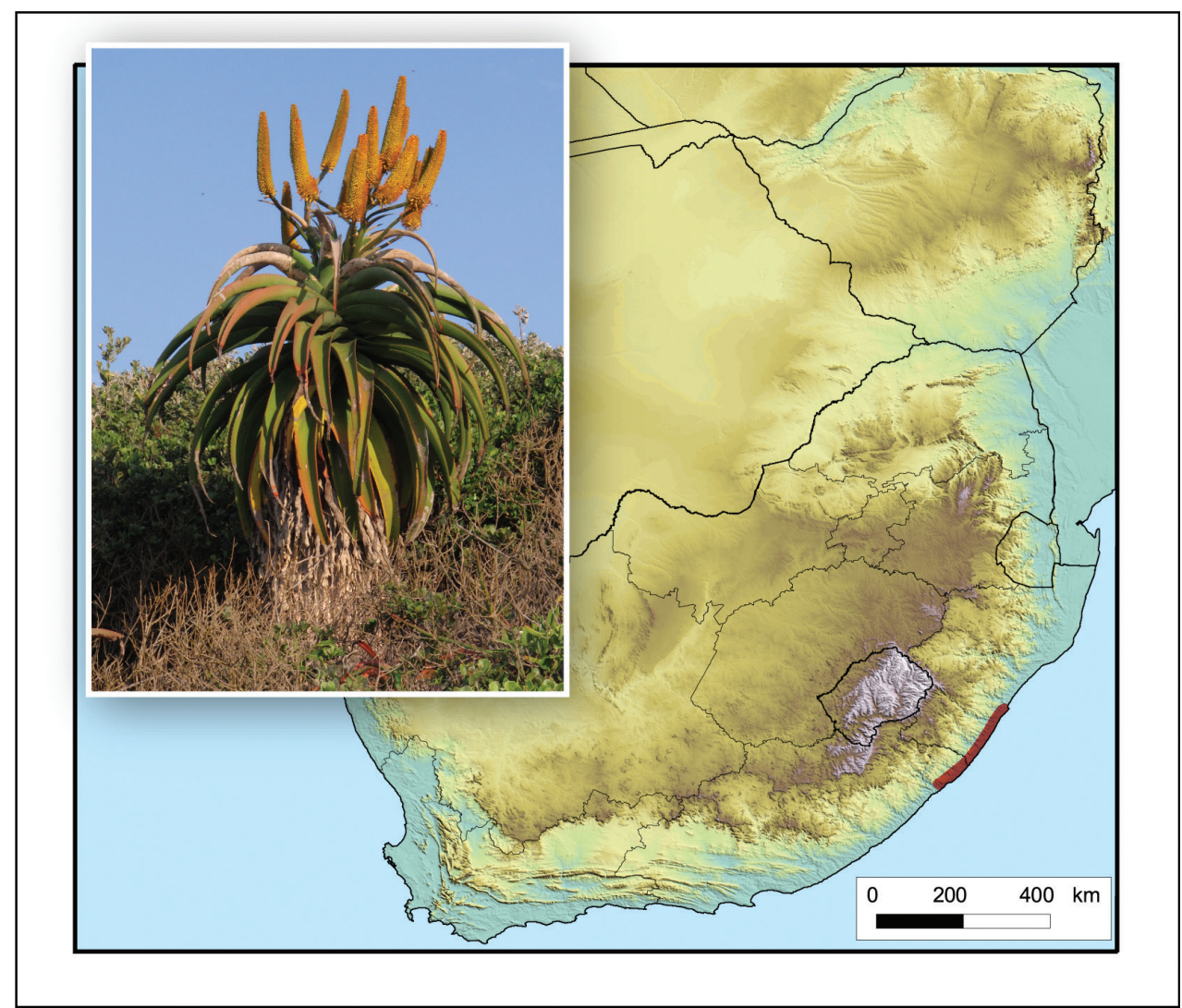

Figure 44. Aloe thraskii. Photo: G. Nichols.

Distribution. Occurs in a narrow coastal strip from the far northern coast of the Eastern Cape into KwaZulu-Natal to just north of Durban, South Africa (Fig. 44).

\section{${ }^{\mathrm{NE}}$ Aloe umfoloziensis Reynolds}

Common names. Groot-bontaalwyn (Afrikaans); icena, ilicena (Zulu).

Description. Acaulescent plant or with short stem, up to $0.4 \mathrm{~m}$ high; rosettes sometimes solitary, usually suckering to form small groups; with persistent dried leaves. Leaves densely rosulate, spreading or deflexed, upper surface green to brownish-green, with numerous dull white oblong spots, irregularly scattered or sometimes in undulating interrupted transverse bands, lower surface paler green, without spots or obscurely to distinctly spotted, usually somewhat lineate, lanceolate-attenuate, up to $20-30 \mathrm{~cm}$ long, 8-9 cm wide, with dried twisted apex; margin with horny, pungent deltoid brown teeth, 3-5 mm long, 10-15 mm apart; exudate honey-coloured, drying purplish. Inflorescence 1.0-1.5 m high, erect, 5- to 8-branched from about middle or above, lowest branch 


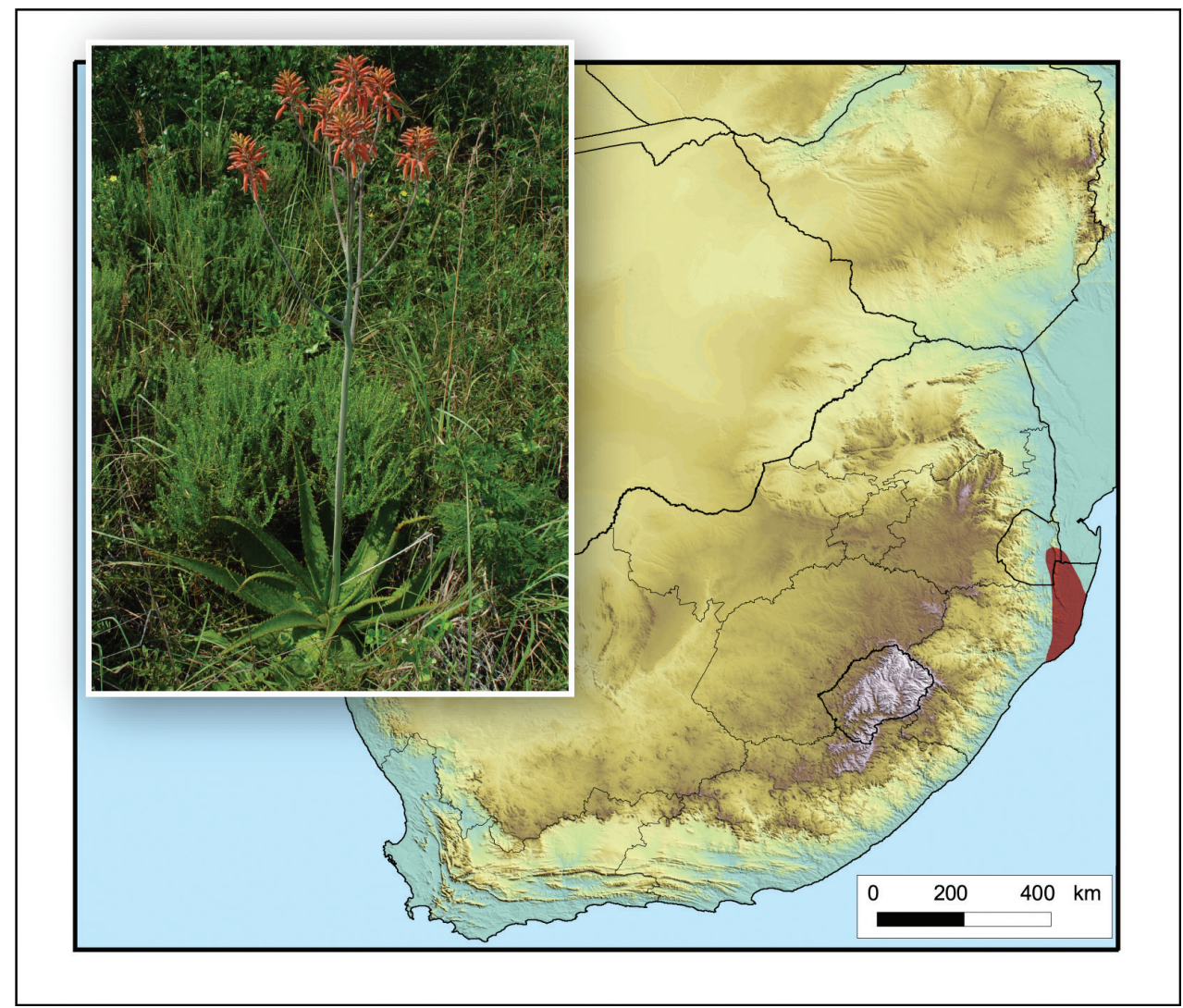

Figure 45. Aloe umfoloziensis. Photo: G. Nichols.

sometimes rebranched. Racemes capitate, apex rounded, 7-9 cm long, 7-9 cm wide, rather dense. Floral bracts $8-12 \mathrm{~mm}$ long. Pedicels $10-15 \mathrm{~mm}$ long. Flowers: perianth coral-red, 33-38 mm long, 8-9 mm across ovary, abruptly constricted above ovary to form subglobose basal swelling, widening towards wide-open mouth, slightly decurved, laterally compressed; outer segments free for 8-9 mm; stamens and style exserted 3-5 mm.

Flowering time. July-August.

Habitat. Low-lying sub-tropical open savannah, open grassland and on rocky places for some distance along rivers and watercourses.

Diagnostic characters. Aloe umfoloziensis can be distinguished from other maculate aloes in KwaZulu-Natal (Aloe dewetii, Aloe maculata subsp. maculata, Aloe mudenensis, Aloe parvibracteata, Aloe prinslooi, Aloe pruinosa, Aloe suffulta, Aloe vanrooyenii and Aloe viridiana) by the tall, 5- to 8-branched, sometimes rebranched, inflorescence (1.0-1.5 $\mathrm{m}$ high) with rather small round-topped capitate racemes $(7-9 \mathrm{~cm}$ long and wide) and pedicels that are 10-15 mm long. Flowers are coral-red, 33-38 $\mathrm{mm}$ long and with a globose basal swelling (8-9 $\mathrm{mm}$ diameter). Leaves are spreading or deflexed, 
up to 20-30 $\times 8-9 \mathrm{~cm}$ and densely spotted on the upper surface, while the paler lower surface is without spots or obscurely to distinctly spotted, usually somewhat lineate. Marginal teeth are 3-5 $\mathrm{mm}$ long.

Conservation status. Near-threatened. Threats include habitat loss and degradation owing to trampling by livestock, erosion and agriculture (L. von Staden pers. comm.).

Distribution. Northern KwaZulu-Natal in South Africa, as well as south-eastern Eswatini and just entering southern Mozambique (Fig. 45).

\section{${ }^{\mathrm{NE}}$ Aloe vanbalenii Pillans}

Common names. Van Balen's aloe (English); rooiblaaraalwyn (Afrikaans); icenalamatshe, incenalendlovu, icenandhlovu, inhlahlwane (Zulu).

Description. Acaulescent plants or stem very short, $0.2-0.3 \mathrm{~m}$ tall, branching at top and base; rosettes suckering to form dense groups, erect. Leaves densely rosulate, spreading to strongly decurved, green to copper red, greener on lower surface, usually obscurely lineate, lanceolate, long attenuate, deeply channelled, 50-80 cm long, 9-15 cm wide; margin somewhat horny, reddish to reddish-brown, with pungent, reddish, deltoid teeth, 3-5 $\mathrm{mm}$ long, 10-15 mm apart; exudate pale honey-coloured. Inflorescence $\pm 1 \mathrm{~m}$ high, erect, 2- or 3-branched from about middle. Racemes narrowly conical, up to $25-30 \mathrm{~cm}$ long, 8-10 cm wide, rather dense. Floral bracts up to $15 \mathrm{~mm}$ long, 6-7 mm wide. Pedicels $14-23 \mathrm{~mm}$ long. Flowers: perianth orangeyellow or sometimes dull reddish-pink in bud, usually buff-yellow or sometimes dull red when mature, 30-40 $\mathrm{mm}$ long, 6-7 $\mathrm{mm}$ across ovary, widening slightly towards wide-open mouth, straight, cylindrical-trigonous, slightly laterally compressed; outer segments free to base; stamens exserted to $10 \mathrm{~mm}$; style exserted $10-12 \mathrm{~mm}$.

Flowering time. June-July.

Habitat. Flat rocks and rocky outcrops with minimal soil in Nkonkoni Veld and Zululand Thornveld. Frost-free area with moderately high summer rainfall.

Diagnostic characters. Aloe vanbalenii can be distinguished from other virtually acaulescent, non-maculate aloes in KwaZulu-Natal (Aristaloe aristata, Aloe chabaudii var. chabaudii, Aloe gerstneri, Aloe pratensis, Aloe reitzii var. vernalis and Aloe suprafolia$t a)$ by its suckering habit that forms dense groups of rosettes. It is further characterised by its much recurved, green to copper red, broad $(50-80 \times 9-15 \mathrm{~cm})$, deeply-channelled leaves with pungent marginal teeth. The inflorescence is erect, $\pm 1 \mathrm{~m}$ high and 2- or 3-branched. Floral bracts are long (up to $15 \mathrm{~mm}$ ) and pedicels erect (14-23 mm long). Flowers are orange-yellow or reddish-pink, 30-40 mm long and not narrowed above the ovary. Leaves have a characteristic cinnamon or musty smell when damaged (Carter et al. 2011).

Conservation status. Least Concern (Raimondo et al. 2009).

Distribution. Confined to the Lebombo Mountain range in northern KwaZuluNatal, South Africa and southern Eswatini (Fig. 46). 


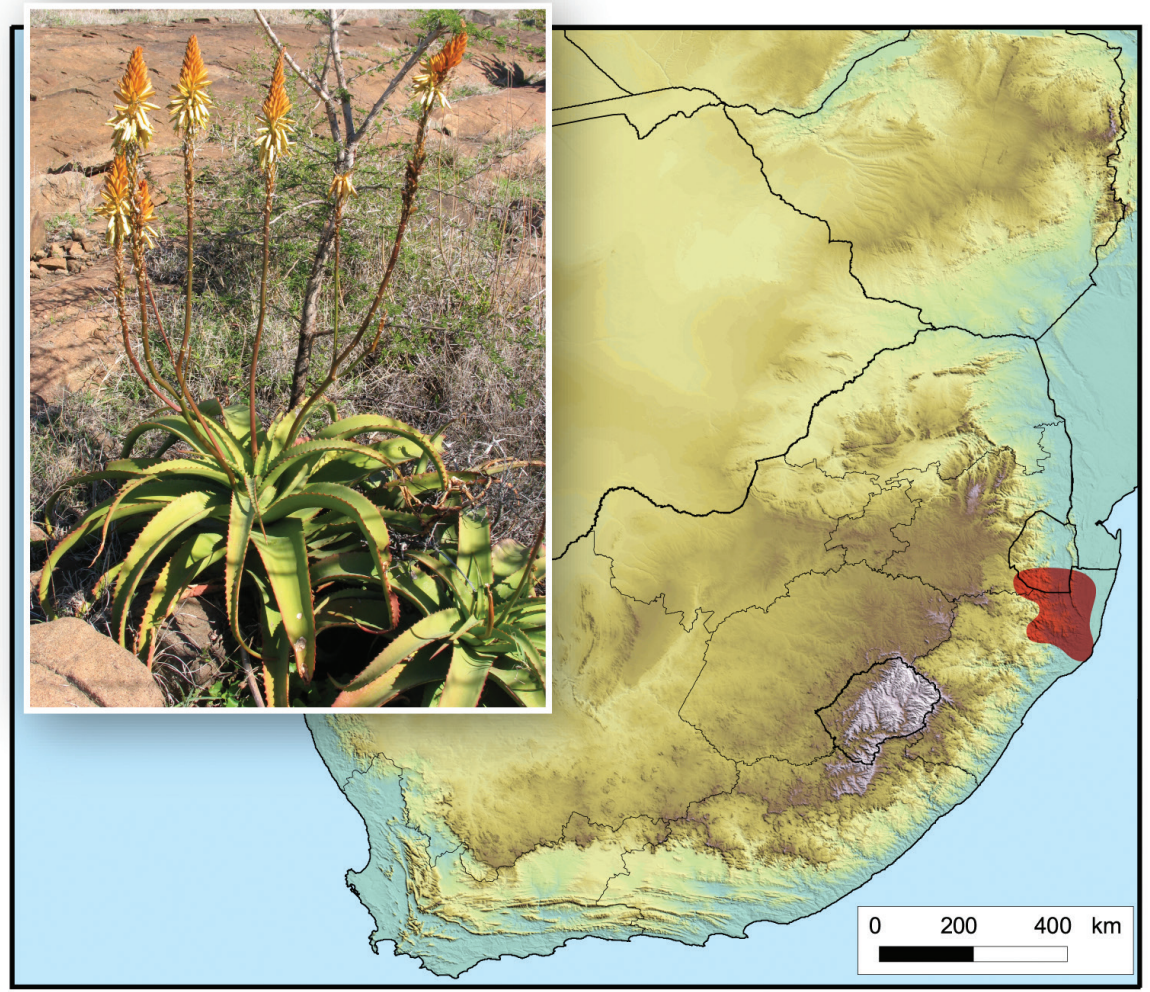

Figure 46. Aloe vanbalenii. Photo: N.R. Crouch.

\section{${ }^{\mathrm{E}}$ Aloe vanrooyenii Gideon F.Sm. \& N.R.Crouch}

Common names. Van Rooyen's aloe (English); vanrooyense-aalwyn (Afrikaans).

Description. Acaulescent plants; rosettes solitary, very rarely suckering to form small groups; with persistent dried leaves. Leaves densely rosulate, distinctly spreading, reflexed, upper surface shiny pale green, with pale milky green to whitish, variously shaped spots, often more or less confluent in transverse bands, lower surface uniformly milky green, rarely with longitudinal darker greenish striations, deltoid-lanceolate, attenuate, 12-15 cm long, 6-8 cm wide, apex dry, sometimes with small teeth at keel near apex; margins whitish, near-translucent, with very pungent, brownish-orange, recurved teeth, 3-4 mm long, 3-4 $\mathrm{mm}$ apart; exudate clear, drying purplish. Inflorescence $0.5-0.8 \mathrm{~m}$ high, erect, 1- or 2-branched below middle. Racemes cylindrical to slightly conical, $25-47 \mathrm{~cm}$ long, 7-9 cm wide, lax. Floral bracts $8-10 \mathrm{~mm}$ long. Pedicels $8-10 \mathrm{~mm}$ long. Flowers: perianth orange or red, 33-38 mm long, $8-10 \mathrm{~mm}$ across ovary, abruptly constricted above ovary to form globose basal swelling, widening towards wide open mouth, cylindrical-trigonous; outer segments free for 8-15 mm; stamens exserted up to $3 \mathrm{~mm}$; style slightly exserted. 


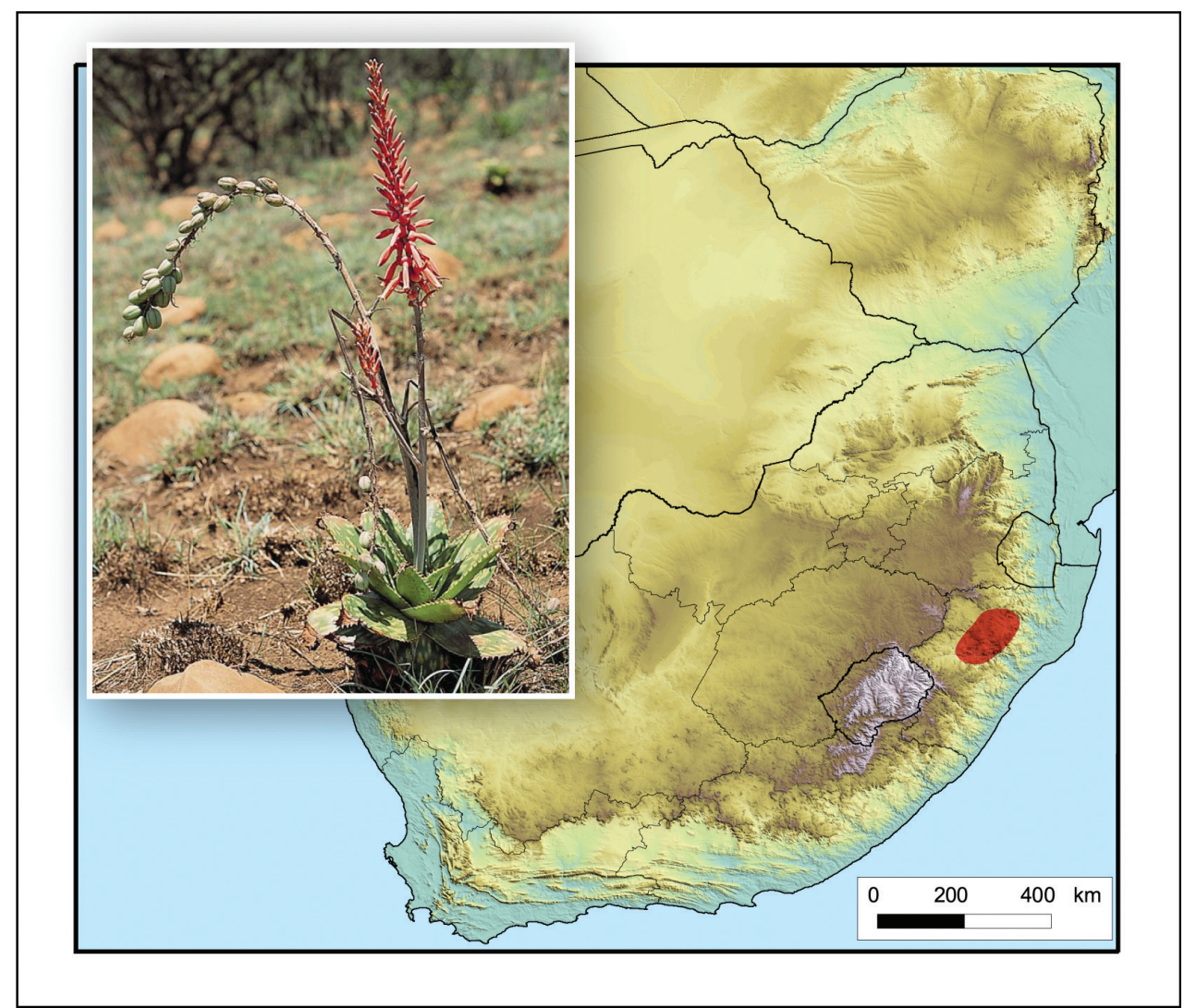

Figure 47. Aloe vanrooyenii. Photo: G.F. Smith.

Flowering time. October-November.

Habitat. Thornveld savannah.

Diagnostic characters. Aloe vanrooyenii can be distinguished from other maculate aloes in KwaZulu-Natal (Aloe dewetii, Aloe maculata subsp. maculata, Aloe mudenensis, Aloe parvibracteata, Aloe prinslooi, Aloe pruinosa, Aloe suffulta, Aloe vanrooyenii and Aloe viridiana) by the 1 - or 2-branched inflorescence with lax, cylindrical to slightly conical racemes $(25-47 \times 7-9 \mathrm{~cm})$ with pedicels $8-10 \mathrm{~mm}$ long. It is further characterised by the very large, erect fruit $(25-28 \times 14-18 \mathrm{~mm}$ in fresh state), which cause the peduncle to bend towards the ground as it cannot support the weight of the large mature capsules. Flowers are orange or red, 33-38 $\mathrm{mm}$ long and with a globose basal swelling (8-10 mm diameter). Leaves are distinctly spreading and reflexed, 12-15 × 6-8 cm and spotted on the upper surface, while the lower surface is rarely lineate. Marginal teeth are $3-4 \mathrm{~mm}$ long. This is the only early summer-flowering maculate aloe in KwaZulu-Natal (Smith and Crouch 2006).

Conservation status. Least Concern (Raimondo et al. 2009).

Distribution. Known from the region linking Ladysmith, Newcastle and Vryheid, KwaZulu-Natal, South Africa (Fig. 47). 


\section{${ }^{\mathrm{E}}$ Aloe viridiana Gideon F.Sm. \& Figueiredo}

Syn. Aloe greenii Baker, nom. illegit.

Common names. Green's aloe (English); groenaalwyn (Afrikaans); icena (isiZulu).

Description. Acaulescent plants; rosettes suckering to form large dense groups, erect, $0.15-0.25 \mathrm{~m}$ high. Leaves densely rosulate, suberect to spreading-recurved, bright green, obscurely lineate, with many confluent oblong white spots forming irregular transverse wavy bands, bands broader and more pronounced on lower surface, broadly linear-lanceolate, gradually attenuate, $\pm 40-50 \mathrm{~cm}$ long, $7-8 \mathrm{~cm}$ wide; margin with deltoid, pale brown to pink teeth, 3-4 mm long, $8-10 \mathrm{~mm}$ apart; exudate clear, drying yellow. Inflorescence $\pm 1.0-1.3 \mathrm{~m}$ high, erect, 5- to 7-branched from above middle, lower branches sometimes rebranched. Racemes oblong-cylindrical, $15-25 \mathrm{~cm}$ long, rather dense. Floral bracts $\pm 10 \mathrm{~mm}$ long, 2-3 mm wide. Pedicels $7-10 \mathrm{~mm}$ long. Flowers: perianth light to dark flesh pink, with powdery bloom, $28-30 \mathrm{~mm}$ long, $\pm 7 \mathrm{~mm}$ across ovary, abruptly constricted above ovary to form globose basal swelling, widening towards mouth, slightly decurved; outer segments free for 7-10 $\mathrm{mm}$; stamens exserted 1-2 mm; style exserted 2-4 mm.

Flowering time. January-March.

Habitat. On stony soil, in low-lying flat sandy areas, often in deep shade or semishade in dry thorny woodland.

Diagnostic characters. Aloe viridiana can be distinguished from other maculate aloes in KwaZulu-Natal (Aloe dewetii, Aloe maculata subsp. maculata, Aloe mudenensis, Aloe parvibracteata, Aloe prinslooi, Aloe pruinosa, Aloe suffulta, Aloe umfoloziensis and Aloe vanrooyenii) by the rosettes that sucker profusely to form large groups. It is further characterised by the recurved leaves $( \pm 40-50 \times 7-8 \mathrm{~cm})$, with spots on both surfaces, but with the markings more pronounced on the lower surface. The 5- to 7-branched inflorescence ( $\pm 1.0-1.3 \mathrm{~m}$ high), that is without a grey bloom, has oblong-cylindrical $(15-25 \mathrm{~cm}$ long), rather dense racemes, with pedicels $7-10 \mathrm{~mm}$ long. Flowers are light to dark flesh pink, with a powdery bloom, 28-30 $\mathrm{mm}$ long and with a globose basal swelling ( $\pm 7 \mathrm{~mm}$ diameter).

Conservation status. Least Concern (Raimondo et al. 2009).

Distribution. Fairly widespread, but uncommon, in eastern KwaZulu-Natal, South Africa. Possibly also in southern Mozambique (Fig. 48). This aloe is not encountered in large numbers where it occurs in the wild.

Notes. This aloe has been known under the name Aloe greenii Baker. However, this validly published name (Baker 1880) is a later illegitimate homonym, as the combination was earlier published as Aloe greenii Green ex Rob. in 1875. The name published by Robinson (1875) cannot, with certainty, be applied to any known maculate aloe owing to the very short descriptive text accompanying the name; however, it was nonetheless validly published. Smith and Figueiredo (2018) provided the necessary replacement name, Aloe viridiana, for material of this KwaZulu-Natal aloe, so providing nomenclatural certainty for material thus far known as A. greenii Baker. 


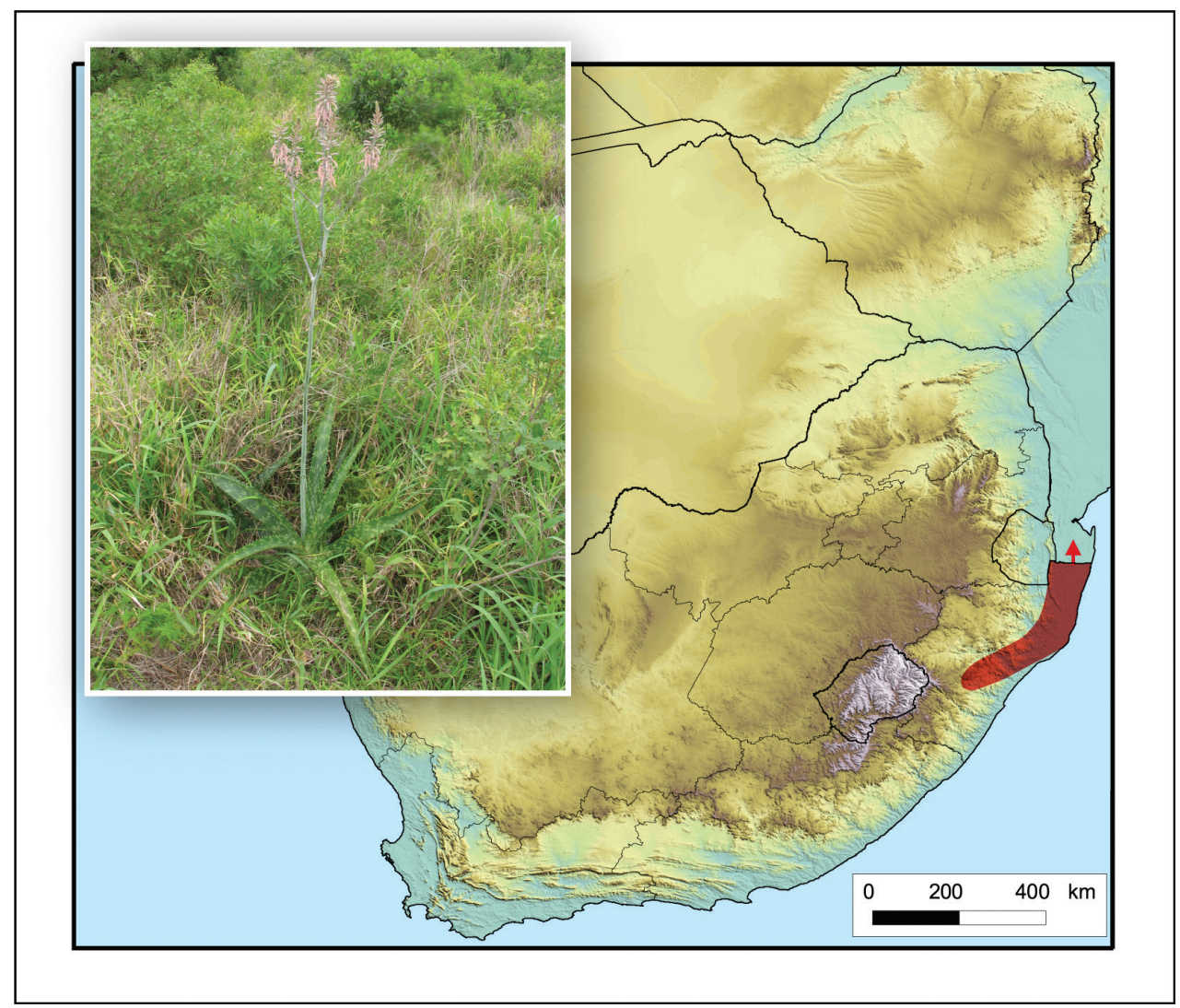

Figure 48. Aloe viridiana. Photo: N.R. Crouch.

\section{Aloe vrybeidensis Groenew.}

Common names. Dolomite aloe, Vryheid aloe (English); bruinaalwyn (Afrikaans).

Description. Acaulescent or arborescent plants or stem up to $2 \mathrm{~m}$ high, procumbent or shortly suberect, unbranched or sometimes branched at base; with persistent dried leaves; rosettes solitary or in small groups. Leaves densely rosulate, arcuate-erect to slightly spreading and recurved, glaucous green to dark green with bluish or reddish tinge, without spots, texture smooth, lanceolate-attenuate, $40-80 \mathrm{~cm}$ long, $9-13 \mathrm{~cm}$ wide at base; margin red, subcorneous, with pungent, deltoid, straight, reddish teeth, 2-3 mm long, 10-15 mm apart; exudate drying yellow. Inflorescences $0.6-1.5 \mathrm{~m}$ high, oblique to erect, simple. Raceme cylindrical, $30-40 \mathrm{~cm}$ long, 5-7 cm wide, erect, very dense. Floral bracts $8-15 \mathrm{~mm}$ long, 5-10 mm wide. Pedicels absent. Flowers: perianth greenish-yellow to reddish in bud, rose-coloured or greenish-yellow to yellowish when mature, 8-20 $\mathrm{mm}$ long, 4-5 mm across ovary, widening to wide open mouth, campanulate-cylindrical; outer segments free to base; stamens exserted 6-15 $\mathrm{mm}$; style exserted 7-17 $\mathrm{mm}$. 


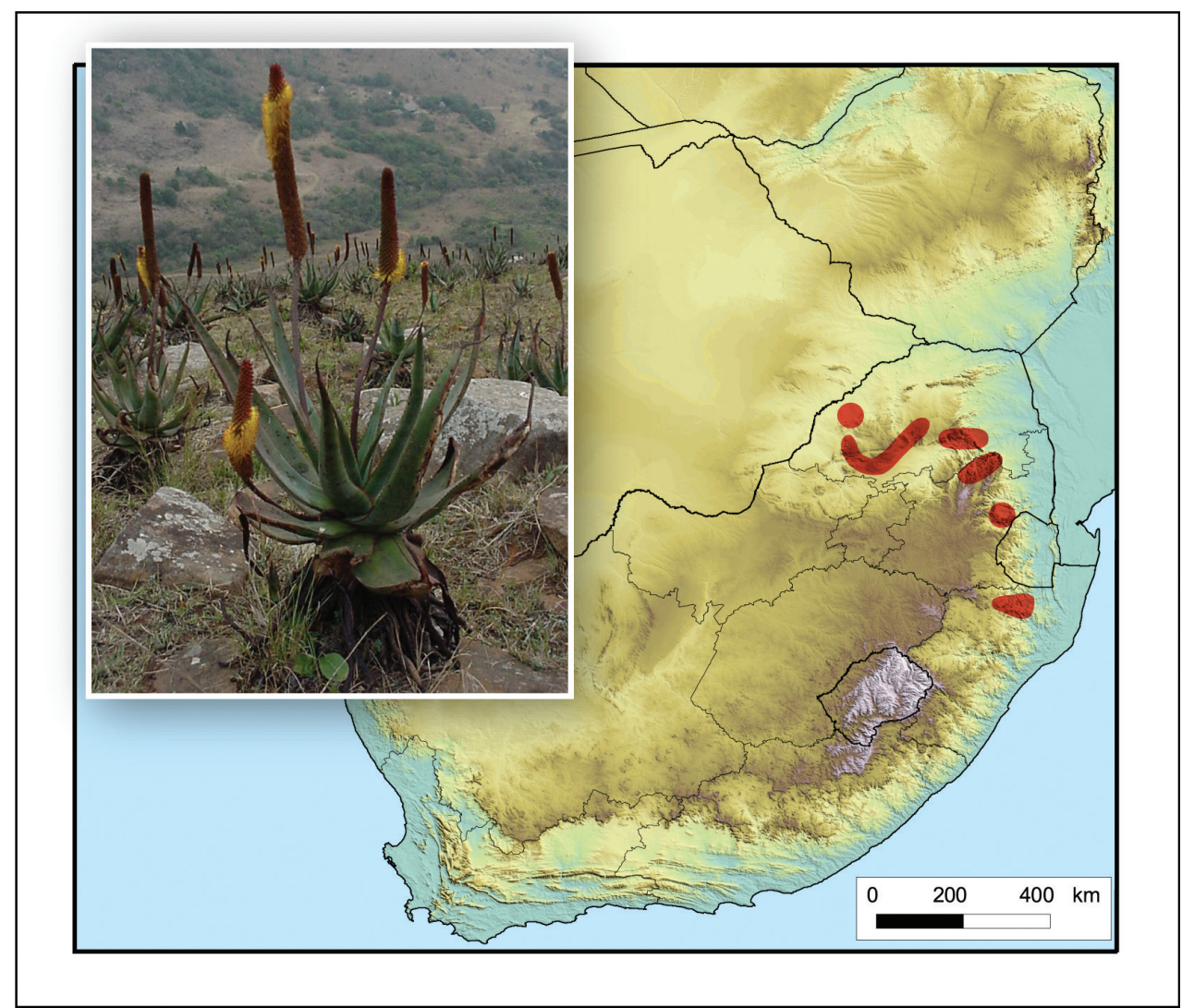

Figure 49. Aloe vryheidensis. Photo: G. Nichols.

Flowering time. July-August.

Habitat. Usually on alkaline soils derived from shale or dolomite (on sandstone at Vryheid).

Diagnostic characters. Aloe vryheidensis is one of only two aloes indigenous to KwaZulu-Natal that have sessile campanulate flowers with dark nectar in a simple inflorescence. It differs from Aloe spicata in having procumbent to shortly sub-erect stems (not erect) that are sometimes absent, arcuate-erect to slightly spreading leaves (not recurved) and an inflorescence with the peduncle oblique (not erect), then bent upwards directly below the erect raceme. The racemes of Aloe vryheidensis are narrow $(5-7 \mathrm{~cm}$ wide), but slightly wider than those of Aloe spicata, with pinkish-brown flowers (not greenish-yellow). The ovary has red lines longitudinally down the 3 broad angles.

Conservation status. Least Concern (L. von Staden pers. comm.).

Distribution. Mountainous areas of northern KwaZulu-Natal, Mpumalanga and Limpopo, South Africa (Fig. 49). 


\section{Acknowledgements}

Special thanks to Ms Lize von Staden, Threatened Plants Programme, South African National Biodiversity Institute, Pretoria, for providing conservation assessments for several taxa; to Dr Hester M. Steyn, National Herbarium, South African National Biodiversity Institute, for providing base maps for the distribution maps and for assistance in generating the biome map; to those who made photographs available; and to the reviewers for suggesting improvements to the manuscript.

\section{References}

Baker JG (1880) Aloe greenii. Native probably of the Cape. Nat. Ord. Liliaceae. - Tribe Aloinex. Curtis's Botanical Magazine, ser. 3, 36: tab. 6520. https://www.biodiversitylibrary.org/ item/14234\#page/159/mode/1up

Burrows JE, Burrows SM, Lötter MC, Schmidt E (2018) Trees and Shrubs Mozambique. Publishing Print Matters (Pty) Ltd., Cape Town.

Carbutt C (2019) The Drakensberg Mountain Centre: A necessary revision of southern Africa's high-elevation centre of plant endemism. South African Journal of Botany 124: 508-529. https://doi.org/10.1016/j.sajb.2019.05.032

Carbutt C, Edwards TJ (2006) The endemic and near-endemic angiosperms of the Drakensberg Alpine Region. South African Journal of Botany 72(1): 105-132. https://doi. org/10.1016/j.sajb.2005.06.001

Carter S (2001) Aloaceae. In: Pope GV (Ed.) Flora Zambesiaca, Vol. 12 part 3. Royal Botanic Garden, Kew, London, 48-98.

Carter S, Lavranos JJ, Newton LE, Walker CC (2011) Aloes: the Definitive Guide. Kew Publishing, Royal Botanic Gardens, Kew / British Cactus \& Succulent Society.

CITES (2018) CITES Appendices I, II and III. http://www.cites.org/eng/app/appendices.php [accessed 12.2018]

Craib C (2005) Grass Aloes of the South African Veld. Umdaus Press, Hatfield, Pretoria.

Crouch NR, Smith GF, Condy G (2011) Aloe nicholsii. Flowering Plants of Africa 62: 16-21.

Crouch NR, Smith GF, Klopper RR, Figueiredo E, McMurtry D, Burns S (2015) Winter-flowering maculate aloes from the Lowveld of southeastern Africa: Notes on Aloe monteiroae Baker (Asphodelaceae: Alooideae), the earliest name for Aloe parvibracteata Schönland. Bradleya 33: 147-155. https://doi.org/10.25223/brad.n33.2015.a20

Cyrus D, Robson N (1980) Bird Atlas of Natal. University of Natal Press, Pietermaritzburg. Dyer RA, Hardy DS (1974) Addendum I. In: Reynolds GW (Ed.) The Aloes of South Africa, $3^{\text {rd }}$ edn. Balkema, Cape Town, 509-516.

Figueiredo E, Smith GF (2012) Clarifying the application of the long-confused name Aloe commutata, and the establishment of Aloe $\times$ commutata Tod. (Asphodelaceae). Bradleya 30: 25-32. https://doi.org/10.25223/brad.n30.2012.a7 
Glen HF, Hardy DS (1987) Nomenclatural notes on three southern African representatives of the genus Aloe. South African Journal of Botany 53(6): 489-492. https://doi.org/10.1016/ S0254-6299(16)31383-7

Glen HF, Hardy DS (2000) Aloaceae (First part): Aloe. In: Germishuizen G (Ed.) Flora of Southern Africa, Vol. 5, Part 1, Fascicle 1. National Botanical Institute, South Africa, 1-167.

Govaerts R (2014) World checklist of Xanthorrhoeaceae: Aloe. Facilitated by the Board of Trustees of the Royal Botanic Gardens, Kew. http://apps.kew.org/wcsp/ [accessed 03.2014]

Grace OM, Klopper RR (2014) Recommendation to the CITES Plants Committee: Name changes affecting Aloe and related genera. https://cites.org/sites/default/files/eng/com/ pc/21/E-PC21-20-2.pdf [accessed 12.2018]

Grace OM, Klopper RR, Figueiredo E, Smith GF (2011) The Aloe Names Book. Strelitzia 28: 1-232. South African National Biodiversity Institute, Pretoria / Royal Botanic Gardens, Kew, Surrey.

Grace OM, Klopper RR, Smith GF, Crouch NR, Figueiredo E, Rønsted N, Van Wyk AE (2013) A revised generic classification for Aloe (Xanthorrhoeaceae subfam. Asphodeloideae). Phytotaxa 76(1): 7-14. https://doi.org/10.11646/phytotaxa.76.1.2

IUCN (2001) IUCN Red List Categories and Criteria: Version 3.1. IUCN Species Survival Commission, Gland, Switzerland and Cambridge, UK.

Jewitt D, Goodman PS, Erasmus BFN, O’Conner TG, Witkowski ETF (2015) Systematic land-cover change in KwaZulu-Natal, South Africa: implications for biodiversity. South African Journal of Science 111: Art. \#2015-0019, 9 pp. https://doi.org/10.17159/ sajs.2015/20150019

Johnson IM, Harvey J, Von Staden L (2011) Aloe neilcrouchii Klopper \& Gideon F.Sm. National Assessment: Red List of South African Plants version 2013.1. http://redlist.sanbi. org/species.php?species=2206-820 [accessed 02.2014]

Killick DJB (1978) The Afro-Alpine Region. In: Werger MJA (Ed.) Biogeography and Ecology of Southern Africa. Junk, The Hague, 515-542. https://doi.org/10.1007/978-94-0099951-0_12

Klopper RR, Smith GF (2010) Aloe neilcrouchii, a new robust leptoaloe from KwaZulu-Natal, South Africa. Bothalia 40: 117-120. https://doi.org/10.4102/abc.v40i1.186

Klopper RR, Zietsman PC, Du Preez PJ, Smith GF (2010) A first record of a South African aloe, Aloe spectabilis, becoming naturalised elsewhere in the country. Bradleya 28: 37-38. https://doi.org/10.25223/brad.n28.2010.a6

Klopper RR, Crouch NR, Smith GF (2015) (2399) Proposal to conserve the name Aloe parvibracteata against $A$. monteiroae (Asphodelaceae: Alooideae). Taxon 64(6): 1320. https:// doi.org/10.12705/646.21

Manning JC, Boatwright JS, Daru BG, Maurin O, Van der Bank M (2014) A molecular phylogeny and generic classification of Asphodelaceae subfamily Alooideae: A final resolution of the prickly issue of polyphyly in the alooids? Systematic Botany 39(1): 55-74. https:// doi.org/10.1600/036364414X678044

McDonald IAW, Jarman ML (1985) Invasive alien plants in the terrestrial ecosystems of Natal, South Africa. South African National Scientific Programmes Report 118. Council for Scientific and Industrial Research, Pretoria. 
Mittermeier RA, Gil PR, Hoffmann M, Pilgrim J, Brooks T, Mittermeier CG, Lamoreux J, Da Fonseca GAB (2004) Hotspots Revisited. CEMEX, Mexico.

Mucina L (2018) Vegetation Survey and Classification of Subtropical Forests of Southern Africa. Geobotany Studies, Springer, Cham. https://doi.org/10.1007/978-3-319-67831-3

Mucina L, Rutherford MC (2006) The Vegetation of South Africa, Lesotho and Swaziland. Strelitzia 19. South African National Biodiversity Institute, Pretoria.

Palmer B, Van der Elst R, Parak O (2011) Understanding Our Coast: A Synopsis of KZN's Coastal Zone. KwaZulu-Natal Department of Agriculture, Environmental Affairs and Rural Development, Cedara, Pietermaritzburg.

Poynton JC (1961) Biogeography of south-east Africa. Nature 189(4767): 801-803. https:// doi.org/10.1038/189801a0

Poynton JC (1962) Patterns in the distribution of southern African amphibia. Annals of the Cape Provincial Museums 2: 152-272.

Province of KwaZulu-Natal (1997) KwaZulu-Natal Nature Conservation Management Act, 9 of 1997. KwaZulu-Natal Legislature.

Raimondo D, Von Staden L (2009) Patterns and trends in the Red List of South African plants. In: Raimondo D, Von Staden L, Foden W, Victor JE, Helme NA, Turner RC, Kamundi DA, Manyama PA (Eds) Red List of South African plants, Strelitzia 25. South African National Biodiversity Institute, Pretoria, 19-40.

Raimondo D, Von Staden L, Foden W, Victor JE, Helme NA, Turner RC, Kamundi DA, Manyama PA (2009) Red List of South African Plants. Strelitzia 25. South African National Biodiversity Institute, Pretoria.

Reynolds GW (1950) The Aloes of South Africa. Aloes of South Africa Book Fund, Johannesburg.

Robinson W (1875) Aloe Greenii (Green). Societies and Exhibitions. Royal Horticultural Society. July $21^{\text {st }}$ and $22^{\text {nd }}$. The Garden (an illustrated weekly journal of gardening in all its branches. London.) VIII: 77-78. https://www.biodiversitylibrary.org/item/82631\#page/93/ mode/1up [accessed 12.2018]

Ross JH (1972) The Flora of Natal. Memoirs of the Botanical Survey of South Africa 39. Department of Agricultural Technical Services, Botanical Research Institute, Pretoria.

Smith GF, Crouch NR (2006) Aloe vanrooyenii: A distinctive new maculate aloe from KwaZulu-Natal, South Africa. Bothalia 36: 73-75. https://doi.org/10.4102/abc.v36i1.342

Smith GF, Figueiredo E (2009) Aloe arborescens Mill. (Asphodelaceae) is spreading in Portugal. Bradleya 27: 165-167. https://doi.org/10.25223/brad.n27.2009.a4

Smith GF, Figueiredo E (2018) Aloe viridiana Gideon F.Sm. \& Figueiredo (Asphodelaceae: Alooideae), a replacement name for the illegitimate Aloe greenii Baker, a maculate aloe endemic to KwaZulu-Natal, South Africa, with notes on the nomenclature of this species. Bradleya 36: 212-217. https://doi.org/10.25223/brad.n36.2018.a16

Smith GF, Willis C (1999) Conquering Crassula in Lesotho's Sehlabathebe National Park. SABONET News 4(2): 157-158.

Smith GF, Crouch NR, Condy G (1999) Aloe pruinosa. Flowering Plants of Africa 56: 2-6.

Smith GF, Crouch NR, Klopper RR, Condy G (2011) Aloe neilcrouchii. Flowering Plants of Africa 62:10-15. 
Smith GF, Klopper RR, Figueiredo E, Crouch NR (2012) Aspects of the taxonomy of Aloe arborescens Mill. (Asphodelaceae: Alooideae). Bradleya 30: 127-137. https://doi.org/10.25223/ brad.n30.2012.a15

Smith GF, Klopper RR, Crouch NR, Figueiredo E (2016) Reinstatement of Aloe candelabrum A.Berger (Asphodelaceae: Alooideae), a tree-like aloe of KwaZulu-Natal province, South Africa. Bradleya 34: 59-69. https://doi.org/10.25223/brad.n34.2016.a21

Steenkamp Y, Van Wyk B, Victor J, Hoare D, Smith G, Dold T, Cowling R (2004) Maputaland-Pondoland-Albany. In: Mittermeier RA, Gil PR, Hoffmann M, Pilgrim J, Brooks T, Mittermeier CG, Lamoreux J, Da Fonseca GAB (Eds) Hotspots Revisited: Earth's Biologically Richest and Most Threatened Terrestrial Ecoregions. Cemex \& Conservation International, Washington, 219-228.

Van der Riet WB (1977) Aloe modesta - our fragrant aloe. Veld \& Flora 63(1): 20-22.

Van Jaarsveld EJ (2010) Aloe tongaensis, a new species from Tongaland, KwaZulu-Natal (South Africa), and a new sectional arrangement of the tree aloes. Aloe 47: 64-71.

Van Jaarsveld E, Judd E (2015) Tree Aloes of Africa. Penrock Publications, Cape Town.

Van Jaarsveld EJ, Van Wyk AE (2005) A new subspecies of Aloe arborescens from the Mzimnyati River, KwaZulu-Natal. Aloe 42: 40-42.

Van Wyk AE (1996) Biodiversity of the Maputaland Centre. In: Van der Maesen LJG, Van der Burgt XM, Van Medenbach de Rooy JM (Eds) The Biodiversity of African Plants, Kluwer Academic Publishers, Dordrecht, 198-207. https://doi.org/10.1007/978-94-009-0285-5_26

Van Wyk AE, Smith GF (2001) Regions of Floristic Endemism in Southern Africa. A Review with Emphasis on Succulents. Umdaus Press, Hatfield, Pretoria.

Von Staden L (2013) Aloe nicholsii Gideon F.Sm. \& N.R.Crouch. National Assessment: Red List of South African Plants version 2017.1. http://redlist.sanbi.org [accessed on 18.02.2019]

Von Staden L (2014a) Aloe bergeriana (Dinter) Boatwr. \& J.C.Manning. National Assessment: Red List of South African Plants version 2017.1. http://redlist.sanbi.org [accessed on 18.02.2019]

Von Staden L (2014b) Aloe sharoniae N.R.Crouch \& Gideon F.Sm. National Assessment: Red List of South African Plants version 2017.1. http://redlist.sanbi.org [accessed on 18.02.2019]

Von Staden L, Nichols G, Grieve G (2013) Aloidendron tongaense (Van Jaarsv.) Klopper \& Gideon F.Sm. National Assessment: Red List of South African Plants version 2017.1. http://redlist.sanbi.org [accessed on 18.02.2019]

Walker CC, Smith GF, Figueiredo E (2019a) Notes on the taxonomy, iconography, and ecology of Aloe pluridens Haw. (Asphodelaceae: Alooideae), an endemic species from southeastern South African. Bradleya 37: 60-72. https://doi.org/10.25223/brad.n37.2019.a28

Walker CC, Smith GF, Figueiredo E, Klopper RR, Crouch NR, Condy G (2019b) Aloidendron barberae. Flowering Plants of Africa 66: 8-21, t.2342.

White F (1983) The vegetation of Africa: A descriptive memoir to accompany the Unesco/ AETFAT/UNSO vegetation map of Africa. Natural Resources Research 20: 1-356.

Wilson KL (2017) Report of the General Committee 18. Taxon 66(3): 742-744. https://doi. org/10.12705/663.15 